\title{
$\begin{array}{r}\text { WAGENINGEN } \\ \text { UNIVERSITY \& RESEARCH } \\ \hline\end{array}$
}

\section{Similar taste-nutrient relationships in commonly consumed Dutch and Malaysian foods}

Teo, P. S., van Langeveld, A. W. B., Pol, K., Siebelink, E., de Graaf, C., Yan, S. W., \& Mars, M.

This is a "Post-Print" accepted manuscript, which has been published in "Appetite"

This version is distributed under a non-commercial no derivatives Creative Commons (a) $(1) \Theta$ reproduction in any medium, provided the original work is properly cited and not used for commercial purposes. Further, the restriction applies that if you remix, transform, or build upon the material, you may not distribute the modified material.

Please cite this publication as follows:

Teo, P. S., van Langeveld, A. W. B., Pol, K., Siebelink, E., de Graaf, C., Yan, S. W., \& Mars, M. (2018). Similar taste-nutrient relationships in commonly consumed Dutch and Malaysian foods. Appetite, 125, 32-41. DOI: 10.1016/j.appet.2018.01.020

You can download the published version at:

https://doi.org/10.1016/j.appet.2018.01.020 


\section{Accepted Manuscript}

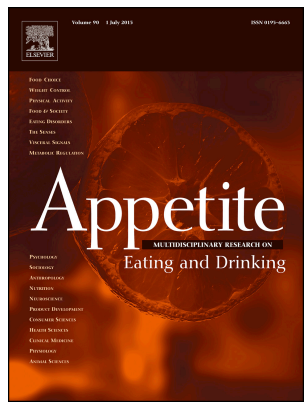

Similar taste-nutrient relationships in commonly consumed Dutch and Malaysian foods

Pey Sze Teo, Astrid W.B. van Langeveld, Korrie Pol, Els Siebelink, Cees de Graaf, See Wan Yan, Monica Mars

PII: S0195-6663(17)31228-X

DOI: 10.1016/j.appet.2018.01.020

Reference: $\quad$ APPET 3759

To appear in: Appetite

Received Date: 18 August 2017

Revised Date: 28 November 2017

Accepted Date: 19 January 2018

Please cite this article as: Teo P.S., van Langeveld A.W.B., Pol K., Siebelink E., de Graaf C., Yan S.W. \& Mars M., Similar taste-nutrient relationships in commonly consumed Dutch and Malaysian foods, Appetite (2018), doi: 10.1016/j.appet.2018.01.020.

This is a PDF file of an unedited manuscript that has been accepted for publication. As a service to our customers we are providing this early version of the manuscript. The manuscript will undergo copyediting, typesetting, and review of the resulting proof before it is published in its final form. Please note that during the production process errors may be discovered which could affect the content, and all legal disclaimers that apply to the journal pertain. 
1 Similar taste-nutrient relationships in commonly consumed Dutch and Malaysian foods

2 Pey Sze Teo MSc ${ }^{\mathrm{a}, \mathrm{b}}$, Astrid W. B. van Langeveld MSc ${ }^{\mathrm{a}}$, Korrie Pol MSc ${ }^{\mathrm{a}}$, Els Siebelink RD ${ }^{\mathrm{a}}$,

3 Cees de Graaf $\mathrm{PhD}^{\mathrm{a}}$, See Wan Yan $\mathrm{PhD}^{\mathrm{b}}$, Monica Mars $\mathrm{PhD}^{\mathrm{a} 1}$

$4{ }^{a}$ Division of Human Nutrition, Wageningen University, PO Box 8129, 6700 EV Wageningen, The

$5 \quad$ Netherlands

$6 \quad{ }^{b}$ Faculty of Health and Medical Sciences, Taylor's University Lakeside Campus, 47500 Subang

7 Jaya, Selangor, Malaysia

8

9 Corresponding Author:

$10{ }^{1}$ Dr. Monica Mars,

11 Division of Human Nutrition, Wageningen University,

12 PO Box 8129, 6700 EV Wageningen, The Netherlands.

13 Phone: $+31(0) 317485340$

14 Email: monica.mars@wur.nl 


\section{Abstract}

Three recent studies showed that taste intensity signals nutrient content. However, current data reflects only the food patterns in Western societies. No study has yet been performed in Asian culture. The Malaysian cuisine represents a mixture of Malay, Chinese and Indian foods. This study aimed to investigate the associations between taste intensity and nutrient content in commonly consumed Dutch (NL) and Malaysian (MY) foods. Perceived intensities of sweetness, sourness, bitterness, umami, saltiness and fat sensation were assessed for 469 Dutch and 423 Malaysian commonly consumed foods representing about $83 \%$ and $88 \%$ of an individual's average daily energy intake in each respective country. We used a trained Dutch $(n=15)$ and Malaysian panel $(n=20)$ with quantitative sensory Spectrum ${ }^{\mathrm{TM}} 100$-point rating scales and reference solutions, R1 (13-point), R2 (33-point) and R3 (67-point). Dutch and Malaysian foods had relatively low mean sourness and bitterness $(<R 1)$, but higher mean sweetness, saltiness and fat sensation (between R1 and R2). Mean umami taste intensity of Malaysian foods (15-point) was higher than that of Dutch foods (8-point). Positive associations were found between sweetness and mono- and disaccharides $\left(\mathrm{R}^{2}=0.67(\mathrm{NL}), 0.38(\mathrm{MY})\right)$, between umami and protein $\left(\mathrm{R}^{2}=0.29(\mathrm{NL}), 0.26(\mathrm{MY})\right)$, between saltiness and sodium $\left(\mathrm{R}^{2}=0.48(\mathrm{NL}), 0.27(\mathrm{MY})\right)$, and between fat sensation and fat content $\left(\mathrm{R}^{2}=0.56(\mathrm{NL}), 0.17(\mathrm{MY})\right)$ in Dutch and Malaysian foods (all, $p<0.001$ ). The associations between taste intensity and nutrient content are not different between different countries, except for fat sensation-fat content. The two dimensional basic tastenutrient space, representing the variance and associations between tastes and nutrients, is similar between Dutch and Malaysian commonly consumed foods. 
40 Keywords:

41 Taste intensity; nutrient content; commonly consumed; foods; cross-cultural

42

43 


\section{Introduction}

The sense of taste plays a pivotal role in food choice and preference (Drewnowski, 1997). It has been hypothesized that taste has a nutrient-signaling function and is able to elicit expectations about foods concerning its macronutrient content (Rozin \& Vollmecke, 1986; Temussi, 2009). Sweet taste, for example, may signal energy and carbohydrate content, umami and salty tastes may signal protein and sodium content, bitter taste may indicate toxic components, and sour taste may indicate ripeness of fruits (Temussi, 2009; Yarmolinsky, Zuker, \& Ryba, 2009). This signaling function of taste has repeatedly been shown to affect the process of satiation, meal termination (Bolhuis, Lakemond, de Wijk, Luning, \& de Graaf, 2011; de Graaf \& Kok, 2010; Weijzen, Smeets, \& de Graaf, 2009). Taste signaling is therefore important in the regulation of food and energy intake (McCrickerd \& Forde, 2016).

There is an enormous societal pressure both in middle and high income countries in the world to reduce salt, sugar and fat levels in foods (World Health Organization, 2013). However, attempts to reduce these levels face the challenge of keeping sensory perceptions of tastes at optimal levels (Zandstra, Lion, \& Newson, 2016). From this perspective it is important to have insight in the relationships between the physical chemical/nutrient composition of commonly consumed foods and the sensory perception of taste.

Taste perception has also been implicated from an obesity perspective. A recent comprehensive review of Cox et. al. (2016) suggested that lower sensitivity to fat taste and higher liking and preference for fat is related to an higher average BMI. There was little evidence of a relationship between sweet, salty, sour or bitter tastes sensitivities, preferences and weight status (Cox, Hendrie, \& Carty, 2016). Since taste plays a prominent role in potential nutrition-related health 
outcomes, it is important to assess the relationship between taste intensity and nutrient content of a wide range of foods representative of diets within and across population.

Only recently studies started to explore the taste-nutrient relationship of commonly consumed foods, in order to better understand the role that taste properties may play in food intake regulation. So far, three studies; originated from the Netherlands (van Dongen, van den Berg, Vink, Kok, \& de Graaf, 2012), Australia (Lease, Hendrie, Poelman, Delahunty, \& Cox, 2016) and United States (van Langeveld, et al., 2017), have described the association of taste intensity and nutrient content within respectively 50, 377 and 237 consumed foods. The three studies consistently observed that sweet, salty, umami and fat sensation were positively associated with respectively mono- and disaccharides, sodium, protein and fat content. Moreover, energy content of consumed foods was positively associated with saltiness but not with sweet taste intensity in the Australian and American foods. However, these studies only investigated the nutrient-taste relationships in Western food patterns.

Food intake usually takes place within a range of familiar foods, which highly depend on cultural exposure and individual experience (Prescott, 1998; Rozin, 1996). The wide variety of regional cuisines makes the taste qualities in foods different all over the world. For instance, Western cuisines tend to pair foods that share flavors; whereas East Asian dishes does opposite and avoid combining similar flavors (Ahn, Ahnert, Bagrow, \& Barabási, 2011). These cultural diversities of culinary practice and food patterns raise the question of whether these general patterns on tastenutrient associations are similar across Western and Asian food patterns. However, up to now, no study has been performed to characterize the taste-nutrient relationships of commonly consumed foods in Asian culture. 
In this paper, we investigate the association between taste intensity and nutrient content in commonly consumed Dutch and Malaysian foods. It was hypothesized that similar taste-nutrient relationships will exist in both Dutch and Malaysian foods regardless of different cultural backgrounds.

\section{Material and methods}

This study linked the taste profiles of commonly consumed foods in The Netherlands and Malaysia with the nutrient content of those foods. The commonly consumed foods have been selected using nation-wide food consumption data from each country.

\section{Panelists}

A Dutch $(n=15)$ and Malaysian trained sensory panel $(n=20)$ was used to describe a wide array of commonly consumed Dutch and Malaysian foods in terms of the intensity of five basic tastes (i.e. sweet, sour, bitter, umami, salt) and fat sensation. The Dutch panel consisted of 3 males and 12 females, with a mean age of $33 \pm 12$ years and a BMI of $23 \pm 2 \mathrm{~kg} / \mathrm{m}^{2}$. The Malaysian panel consisted of 3 males and 17 females, with a mean age of $21 \pm 3$ years and a BMI of $22 \pm 4 \mathrm{~kg} / \mathrm{m}^{2}$. Both panels were screened for good sensory ability and trained intensively (56-63 hours, 6 months) using 100-point Spectrum ${ }^{\mathrm{TM}}$ inspired quantitative reference rating scales (Martin, Visalli, Lange, Schlich, \& Issanchou, 2014; Muñoz. \& Civille, 1992). (Teo et al., under review) All panelists signed an informed consent form and received financial compensation for participation in the study. The study has been approved by the Human Ethics Review Committee 
of Wageningen University (ABR number: NL47315.081.13) and Taylor's University (Ethics reference number: HEC/2015/SBS/023). The study was conducted according to the declaration of Helsinki and registered on ClinicalTrials.gov (NCT03233503).

\section{Panel training}

Both panels received an intensive training to evaluate the intensity of sweetness, sourness, bitterness, umami, saltiness and fat sensation. Panelists were trained using basic sapid taste solutions, followed by simple modified products and commercially available food products. Spectrum-based basic solutions were available with fixed reference points at 13.3 point (R1), 33.3 point (R2) and 66.7 point (R3) for each taste modality on a 100-point rating scale. For saltiness, the positions of R1 (16.7 point) and R3 (56.7 point) were different. Basic solutions contained increasing concentrations of sucrose for sweetness, sodium chloride $(\mathrm{NaCl})$ for saltiness, monosodium glutamate (MSG) for umami, citric acid for sourness and caffeine for bitterness. The taste compounds were dissolved in mineral water (Evian®, Évian-les-Bains, France). The reference solutions on the rating scales were obtained from the Spectrum ${ }^{\mathrm{TM}}$ method (Muñoz. \& Civille, 1992). MSG concentrations for umami taste were adapted from the previous work of the Dijon group (Martin, Tavares, Schwartz, Nicklaus, \& Issanchou, 2009). Next, panelists were trained using simple food matrices which were modified with varying concentrations of taste substances. For instance, $\mathrm{NaCl}$ and MSG were added to mashed potatoes and cooked rice for saltiness and umami; caffeine and citric acid were added to agar for bitterness and sourness; sucrose was added to gelatin for sweetness; and mascarpone was added to vanilla custard for fat sensation. This part of training was completed when the panels were able to 
131 discriminate different taste intensities and reproduce taste values in samples with different

132 textural conditions.

133 Panelists then discussed, evaluated and rated perceived taste intensity of pre-selected

134 commercially available reference foods on the line scales with the aid of the reference solutions.

135 Foods with the largest variability between panelists were then excluded. Group discussions and

136 individual training were repeated until consensus about taste and fat sensation of reference

137 products was reached (i.e. each mean taste value was remained as non-statistically significantly

138 different, and a coefficient of variation lower than $50 \%$ was obtained). The panels also received

139 additional training sessions with regard to the taste attributes that appeared to be more difficult

140 based on the results of the panel agreement, i.e. umami, bitter and fat sensation. At the end of

141 training procedure, this resulted in 26 additional reference positions on the six rating scales, with

142 the reference foods being specifically targeted for Dutch and Malaysian panel (see Table 1.) (Teo

143 et al, under review). 
Table 1. Reference solutions, reference foods, and their fixed position on the 100-point rating scales

\begin{tabular}{|c|c|c|c|c|c|c|}
\hline \multirow[t]{2}{*}{ Sensation } & \multicolumn{2}{|l|}{ Reference solutions } & \multicolumn{2}{|l|}{ Dutch reference foods } & Malaysian reference foods & \multirow[b]{2}{*}{$\%$ scale } \\
\hline & Solution & $\%$ scale & Food & $\%$ scale & Food & \\
\hline \multirow[t]{5}{*}{ Sweet } & Sucrose $20 \mathrm{gL}^{-1}(\mathrm{R} 1)$ & $13^{\mathrm{a}}$ & Knappertjes (biscuits) Verkade® & 20 & Marie biscuits Munchy® & 21 \\
\hline & Sucrose $50 \mathrm{gL}^{-1}(\mathrm{R} 2)$ & $33^{\mathrm{a}}$ & Vanilla vla (Vanilla custard) Friesland Campina ${ }^{\circledR}$ & 33 & Tiger biscuits Mondelez International ${ }^{\circledR}$ & 39 \\
\hline & Sucrose $100 \mathrm{gL}^{-1}(\mathrm{R} 3)$ & $67^{\mathrm{a}}$ & Sponge cake Albert Heijn home brand $®$ & 50 & & \\
\hline & & & Marshmallow Haribo ${ }^{\circledR}$ & 67 & Marshmallow Haribo® & 64 \\
\hline & & & Sweetened condensed milk Friesland Campina ${ }^{\circledR}$ & 88 & Sweetened condensed milk Teapot ${ }^{\circledR}$ & 83 \\
\hline \multirow[t]{5}{*}{ Sour } & Citric acid $0.50 \mathrm{gL}^{-1}(\mathrm{R} 1)$ & $13^{\mathrm{a}}$ & Rye bread Bolletje ${ }^{\circledR}$ & 15 & Buttermilk Pauls® & 39 \\
\hline & Citric acid $0.80 \mathrm{gL}^{-1}(\mathrm{R} 2)$ & $33^{\mathrm{a}}$ & Buttermilk Albert Heijn Puur en Biologisch $®$ & 38 & Baby pickles Printana ${ }^{\circledR}$ & 57 \\
\hline & Citric acid $1.50 \mathrm{gL}^{-1}(\mathrm{R} 3)$ & $67^{\mathrm{a}}$ & Biogarde (yogurt) Albert Heijn home brand $®$ & 50 & & \\
\hline & & & Sour pickles Albert Heijn home brand $®$ & 78 & Natural yogurt Dutch Lady® & 70 \\
\hline & & & Bottled lemon juice Albert Heijn home brand® & 97 & Bottled lemon juice Sunshine ${ }^{\circledR}$ & 94 \\
\hline \multirow[t]{4}{*}{ Bitter } & Caffeine $0.50 \mathrm{gL}^{-1}(\mathrm{R} 1)$ & $13^{\mathrm{a}}$ & & & Bottled unsweetened oolong tea Pokka ${ }^{\circledR}$ & 15 \\
\hline & Caffeine $0.80 \mathrm{gL}^{-1}(\mathrm{R} 2)$ & $33^{\mathrm{a}}$ & & & Bottled unsweetened Japanese green tea Pokka® & 23 \\
\hline & Caffeine $1.50 \mathrm{gL}^{-1}(\mathrm{R} 3)$ & $67^{\mathrm{a}}$ & Grapefruit juice Albert Heijn home brand® & 57 & Grapefruit juice Florida Natural® & 57 \\
\hline & & & Black chocolate $85 \%$ cocoa Lindt Excellence ${ }^{\circledR}$ & 70 & Black chocolate $85 \%$ cocoa Lindt Excellence $®$ & 72 \\
\hline \multirow[t]{4}{*}{ Umami } & MSG $1.20 \mathrm{gL}^{-1}(\mathrm{R} 1)$ & $13^{\mathrm{b}}$ & Non-fried natural seaweed Nori® & 28 & Roasted seaweed Nico-nico® & 25 \\
\hline & MSG $3.00 \mathrm{gL}^{-1}(\mathrm{R} 2)$ & $33^{\mathrm{b}}$ & Crab sticks Vici® & 43 & Prawn crackers Double Decker® & 47 \\
\hline & MSG $7.00 \mathrm{gL}^{-1}(\mathrm{R} 3)$ & $67^{\mathrm{b}}$ & Parmesan Cheese Grana Padano ${ }^{\circledR}$ & 69 & Parmesan Cheese Grana Padano® & 70 \\
\hline & & & Soy Sauce Kikkoman ${ }^{\circledR}$ & 86 & Soy Sauce Kikkoman ${ }^{\circledR}$ & 80 \\
\hline \multirow[t]{5}{*}{ Salty } & $\mathrm{NaCl} 2.00 \mathrm{gL}^{-1}(\mathrm{R} 1)$ & $17^{\mathrm{a}}$ & Cracotte natural (crispbread) LU® & 14 & Jacob's low salt and hi-fiber crackers $\mathrm{Kraft}^{\circledR}$ & 8 \\
\hline & $\mathrm{NaCl} 3.50 \mathrm{gL}^{-1}(\mathrm{R} 2)$ & $33^{\mathrm{a}}$ & & & Cream cracker Hup Seng® & 25 \\
\hline & $\mathrm{NaCl} 5.00 \mathrm{gL}^{-1}(\mathrm{R} 3)$ & $57^{\mathrm{a}}$ & Potato chips natural Pringles $®$ & 48 & Potato chips natural Pringles ${ }^{\circledR}$ & 41 \\
\hline & & & Old cheese $48+$ Old Amsterdam ${ }^{\circledR}$ & 74 & Old cheese $48+$ Old Amsterdam ${ }^{\circledR}$ & 64 \\
\hline & & & Soy sauce Kikkoman ${ }^{\circledR}$ & 94 & Soy sauce Kikkoman ${ }^{\circledR}$ & 91 \\
\hline & & & Melba ${ }^{\circledR}$ toast & 0 & Original crispy rye bread Wasa ${ }^{\circledR}$ & 0 \\
\hline \multirow[t]{5}{*}{ sensation } & & & Snackcups natural round (crackers) Haust ${ }^{\circledR}$ & 9 & Ritz original crackers Mondelez International ${ }^{\circledR}$ & 21 \\
\hline & & & Slagroomvla (cream custard) Friesland Campina ${ }^{\circledR}$ & 55 & Cream cheese original $60 \%$ less fat Philadelphia ${ }^{\circledR}$ & 54 \\
\hline & & & Cream cheese original Philadelphia ${ }^{\circledR}$ & 72 & Swiss white chocolate classic Lindt $₫$ & 76 \\
\hline & & & White chocolate Verkade ${ }^{\circledR}$ & 73 & & \\
\hline & & & Unsalted butter Friesland Campina ${ }^{\circledR}$ & 97 & Unsalted butter Devondale $®$ & 97 \\
\hline
\end{tabular}


146

147

148

149

150

151

152

153

154

155

156

157

158

159

160

161

162

163

164

Panel performance

Both panels were instructed to evaluate an identical set of 19 control products in terms of six taste attributes to assess their performance. Panel performance measures (discriminative power, agreement, and reproducibility) were regularly monitored during training and profiling sessions.

Oral feedback was given by the researcher to improve the panels' performance.

In general, the training procedure yielded two panels that were similar in panel performance but with a different cultural background. Both panels were able to discriminate between solutions and products, and the majority of the taste values could be reproduced. More importantly, two panels obtained similar taste profiles for a selection of 19 control foods (see Figure 1).

The detailed training procedure and quantitative data regarding panel performance are described in Teo et al. (under review).

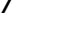




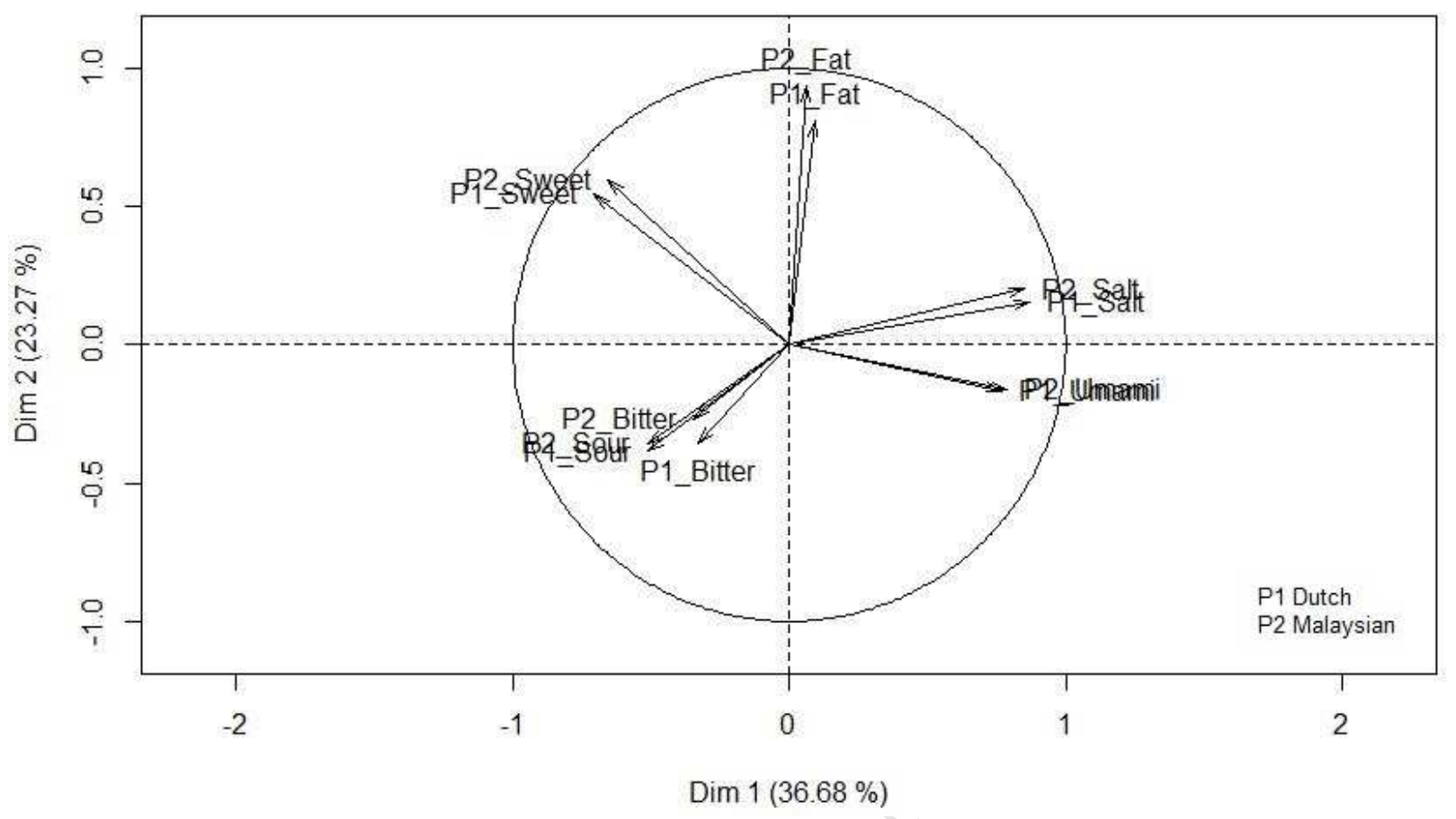

Figure 1. Taste attributes rating consistency of a total of 19 control products across two panels. 
Selection of commonly consumed foods

Dutch foods- Dutch National Food Consumption Surveys (DNFCS 2007-2010)

The commonly consumed foods were selected based on a two-day 24 hour dietary recall (24hDR) data on a representative sample of 1402 Dutch adults (704 males, 698 females), aged 19-50 years (DFCNS 2007-2010) (Van Rossum, Fransen, Verkaik-Kloosterman, Buurma-Rethans, \& Ocké, 2011). The mean age of the respondents was $33 \pm 9$ years, with the body mass index (BMI) of $25 \pm 5 \mathrm{~kg} / \mathrm{m}^{2}$. These food items were selected based on several criteria, i.e. their contribution to the consumption of energy and macronutrients, as well as the consumption frequency. Single food items like raw ingredients used for cooking/ baking (e.g. oil) and condiments (e.g. ketchup) were also included in the food selection, based on how they were reported in $24 \mathrm{hDR}$ of Dutch dataset. This resulted in a list of 469 commonly consumed foods that contributed to $83 \%$ of energy intake, $82 \%$ of protein, $79 \%$ of fat, and $88 \%$ of carbohydrate for an average individual per day consumption. In addition, we consulted the experts (i.e. dietitian) to select one of the frequent consumed brands. Of 469 Dutch foods, $71 \%$ of them were non-cooked foods, that is those foods are readily eaten after purchased from retail stores without any preparation or heating process such as cookies, breads, cakes, and fruits; whilst $29 \%$ of them were cooked foods which need to be further prepared (i.e. minimal cooking or heating) before eaten including mixed dishes, frozen foods, sausages and instant noodles/ soups.

\section{Malaysian foods- Malaysian Adults Nutrition Surveys (MANS 2014)}

The food frequency questionnaire (FFQ) data of MANS 2014 was used to select the commonly consumed Malaysian foods (Institute for Public Health, 2014). It consisted of 165 food items. 
This FFQ survey was conducted on a nationwide sample of 3000 Malaysian adults (1388 males, 1612 females), aged 18-59 years, living in Peninsular and East Malaysia. The mean age of the respondents was $38 \pm 11$ years, with a BMI of $26 \pm 8 \mathrm{~kg} / \mathrm{m}^{2}$. In this study, a systematic approach was used for food selection. First, food items with a prevalence of consumption $>20 \%$ were selected from a total of 165 items. This resulted in a preliminary list of 120 food items.

Given the simplification of food items in FFQ, it was impractical to conduct sensory testing on only 120 general food items. For example, a general food item of "leafy green vegetables" could consist of mustard leaves, water convolvulus, Chinese kale, spinach and sweet leaf bush. Therefore, we further detailed individual food items from those 120 foods based on the accessibility of foods in market, popularity of foods using a food composition database, and sensory differences due to different culinary practices. The single food items including raw ingredients for cooking (i.e. oil, chili) and condiments (i.e. fish sauce) were not considered as a single food, but prepared with other ingredients as a dish according to how they were reported in the 24hDR of MANS dataset (see sub-section Dutch foods). The importance of these selected foods in diets were then evaluated for their energy and macronutrients contribution, and the energy intake variations using a MANS 2014 24hDR data. This resulted in a list of 423 common foods that contributed to $88 \%, 85 \%, 90 \%$ and $88 \%$ of the average person's daily energy, protein, fat, and carbohydrate intakes, respectively. In addition, the expert knowledge (i.e. dietitian) was consulted for the most frequent consumed brands and commonly applied cooking methods. Of 423 Malaysian foods, $34 \%$ of them were non-cooked foods, i.e. readily eaten after purchased from retail stores without any preparation or heating process; whereas $66 \%$ of them were cooked foods, i.e. need to be further prepared including minimal cooking or heating before eaten. 
225 Sample preparation and assessment

226 Dutch food samples

227 The selected foods were purchased at retail stores and were prepared according to the description

228 of the foods in the food composition database (e.g. fried, baked, boiled etc.), and on-pack

229 instructions. Expert knowledge was used for the standardized procedures of cooking (Henderson,

230 1999), e.g. the specific amount of water and time that was needed to boil different types of

231 vegetables.

Malaysian food samples

The selected commercially available foods were purchased at the retail stores and prepared in line with the description of the foods in the database and on-pack instructions. Those purchased foods were mostly ready-to-eat products (e.g. biscuits, juices) or simple foods with minimal cooking efforts (e.g. cooked white rice, hard-boiled eggs). The common complex cooked dishes were purchased from the food service outlets around Subang Jaya area by using a convenience sampling approach. In the Malaysian setting, the approach of buying outside foods was used as more than 64\% outside-home food consumption was reported in Malaysian population (Poulain, Tibère, Laporte, \& Mognard, 2014). Prior to any purchase, a cooked dish was tasted and confirmed as a common dish on the outlet's menu. The recipe was also asked from the food providers.

\section{Sample preparation and evaluation}


The sample preparation and evaluation was similar in both countries. Each evaluation sample was prepared as approximately $15 \mathrm{ml}$ or $15 \mathrm{~g}$, and presented in a $30 \mathrm{ml}$ plastic cup using a standardized protocol. Samples were presented blind with random 3-digit codes and served under serving temperatures based on the norms. For example, cold foods were served at $4-9^{\circ} \mathrm{C}$, hot foods were served at $60-65^{\circ} \mathrm{C}$ and others were served at room temperature of $20-25^{\circ} \mathrm{C}$. If foods were heterogeneous or mixed in composition (i.e. a fried rice with shrimps and vegetables), a representative portion was provided to each panelist. Panelists were instructed to consume the entire amount and rate all six taste attributes on 100-point anchored reference scales with aid of reference solutions and products (See Table 1.). Before and after each food item was tested, panelists neutralized their mouth with a plain cracker and by rinsing with mineral water (Evian®), Évian-les-Bains, France). All samples were evaluated under white light in sensory booths and the sensory assessments were conducted by means of EyeQuestion ${ }^{\circledR}$ software (Logic8, BV, Gelderland, The Netherlands). All samples were tested in three replicates and a maximum of nine samples were tasted in a session, where each session lasted for 1.5 hours.

Nutrient contents of selected Dutch and Malaysian foods

Dutch foods

The nutrient composition of Dutch foods was obtained from the Dutch Food Composition Table (NEVO), a database that contains information on the composition of foods and dishes eaten frequently by a large part of Dutch population (Westenbrink, Jansen-van der Vliet, Castenmiller, Grit, \& Verheijen, 2016) and food product labels. Recipe calculation was used in estimating the nutrients of foods that were prepared with baking or cooking fats (e.g. fried meat) and beverages 
with added milk or sugars (e.g. coffee and tea). The nutrients that were used in the analyses included: energy $(\mathrm{kcal} / 100 \mathrm{~g})$, protein $(\mathrm{g} / 100 \mathrm{~g})$, fat $(\mathrm{g} / 100 \mathrm{~g})$, carbohydrates $(\mathrm{g} / 100 \mathrm{~g})$, mono-and disaccharides $(\mathrm{g} / 100 \mathrm{~g})$, dietary fiber $(\mathrm{g} / 100 \mathrm{~g})$ and sodium $(\mathrm{mg} / 100 \mathrm{~g})$.

\section{Malaysian foods}

Nutrient values of each food item were obtained from the Nutrient Composition of Malaysian foods (Tee, Noor, Azudin, \& Idris, 1997), Energy and Nutrient Composition of Singaporean foods (Food composition guide Singapore, 2011) and food product labels. Recipe calculations were used to estimate the nutrient content of the complex cooked dishes and mixed beverages. The nutrients of interest in this analyses were energy (kcal/100g), protein $(\mathrm{g} / 100 \mathrm{~g})$, fat $(\mathrm{g} / 100 \mathrm{~g})$, carbohydrates $(\mathrm{g} / 100 \mathrm{~g})$, mono-and disaccharides $(\mathrm{g} / 100 \mathrm{~g})$, dietary fiber $(\mathrm{g} / 100 \mathrm{~g})$ and sodium $(\mathrm{mg} / 100 \mathrm{~g})$. No data of mono-and disaccharides and dietary fiber was available in the Malaysian nutrient composition database. Therefore, the total sugar content and dietary fiber of Singapore food database was used (Food composition guide Singapore, 2011). In case dietary fiber and mono- and disaccharides were not available in the Singapore food database, the USDA National Nutrient Database for Standard Reference (United States Department of Agriculture \& Agricultural Research Service, 2008) was used.

\section{Statistical analysis}

A total of 469 Dutch foods and 423 Malaysian foods was included in the data analysis. Statistical analysis was performed using IBM SPSS Statistics (version 22.0, IBM Corp., Armonk, New York, USA) and a $p<0.05$ was considered significant. 
A separate hierarchical cluster analysis was performed on 469 Dutch and 423 Malaysian foods to identify similar groups of food items, based on the 5 basic tastes and fat sensation intensity values. Since different food items were used from the two countries, separate cluster analysis was used for the Dutch and Malaysian database. The number of clusters was decided using Ward's method (Ward, 1963). Six Dutch and five Malaysian food taste clusters were identified, which accounted for $73 \%\left(\mathrm{R}^{2}=0.73\right)$ and $70 \%\left(\mathrm{R}^{2}=0.70\right)$ of the variance, respectively. The identified Dutch and Malaysian food taste clusters were further explored in biplots for validation purpose (data not shown).

Pearson's correlations were also calculated between sweet, sour, bitter, umami, salt and fat sensation. Simple linear regression analysis was performed between taste intensity rating and nutrient content separately for Dutch and Malaysian foods. The differences of taste-nutrient associations between two countries were further compared by their $95 \%$ confidence intervals on Pearson's correlation, using Fisher's z' transformation.

In addition, the biplot representations of principle component analysis (PCA) with taste attributes as active variables and nutrient content was supplementary variables was conducted for both Dutch and Malaysian foods. The PCAs were performed to visualize the relationships between the tastes and nutrient content in two countries, using statistical package R (Rstudio Inc; version 1.0.136).

A full list of the Dutch and Malaysian foods that were profiled and clustered according to taste is shown in supplemental Table $\mathbf{S 1}$ and $\mathbf{S 2}$.

\section{Results}


Taste intensity and nutrient content of the Dutch and Malaysian foods

Table 2. shows the distribution of taste intensity of 469 selected Dutch and 423 selected

Malaysian foods. Both Dutch and Malaysian foods had mean taste intensity ratings below 13.3 point (R1) for sourness and bitterness; whereas sweetness, saltiness and fat sensation of both foods were in the first third of a 100-point scale. Malaysian foods had a mean umami taste ranged between R1and R2 (33.3point); whilst umami taste of Dutch foods was below R1.

In general, Dutch and Malaysian foods showed no significant differences in the level of sweetness. Dutch foods were significantly higher in sour (11 vs. 7point), bitter (4 vs. 3point) and fat sensation (31 vs. 24point) tastes, but lower in salt (17vs. 19point) and umami (8vs. 15point) tastes compared to Malaysian foods. Although the mean taste intensities of foods were statistically significant different between two countries, the differences were observed as smaller than 7 points, on 100-point $S_{\text {Spectrum }}{ }^{\mathrm{TM}}$ taste scales. With regard to nutrient content, Dutch foods had higher energy density (256 vs. 197kcal), fat (14 vs. 8g) and mono- and disaccharides content (13 vs. 9g) compared to Malaysian foods $(p<0.01)$.

Of 919 total profiled foods, $54 \%$ and $46 \%$ were categorised in non-cooked and cooked foods respectively. Most of the non-cooked foods were the foods from the sweet and fatty cluster, while the cooked foods were mainly from the cluster of savoury and fatty. In the subgroup of noncooked foods, Dutch foods were significantly higher in salt taste (15 vs. 8point) and fat sensation (32 vs. 15point) compared to Malaysian foods. Whilst, Dutch cooked foods were significantly higher in bitter (6 vs. 2point) but lower in sweet (8vs. 15point) and umami (14 vs. 20point) tastes compared to Malaysian cooked foods. 
Table 2. Distribution of taste intensity values and nutrient content of 469 common Dutch and 423 Malaysian foods

\begin{tabular}{|c|c|c|c|c|c|c|c|c|c|c|c|c|c|c|}
\hline & \multicolumn{7}{|c|}{ Dutch foods } & \multicolumn{7}{|c|}{ Malaysian foods } \\
\hline & Mean & SD & $0 \%$ & Q1 & Median & Q3 & $100 \%$ & Mean & SD & $0 \%$ & Q1 & Median & Q3 & $100 \%$ \\
\hline \multicolumn{15}{|l|}{ Taste intensity } \\
\hline Sweet & 22 & 20 & 1 & 6 & 11 & 39 & 76 & 20 & 17 & 1 & 6 & 13 & 34 & 72 \\
\hline Sour & $11^{* *}$ & 14 & 0 & 2 & 4 & 14 & 73 & 7 & 10 & 0 & 1 & 2 & 8 & 51 \\
\hline Bitter & $4^{* *}$ & 9 & 0 & 1 & 1 & 3 & 63 & 3 & 7 & 0 & 0 & 1 & 2 & 68 \\
\hline Umami & $8^{* *}$ & 11 & 0 & 1 & 1 & 14 & 64 & 15 & 14 & 0 & 1 & 13 & 28 & 48 \\
\hline Salt & $17^{*}$ & 17 & 0 & 3 & 11 & 32 & 67 & 19 & 14 & 0 & 3 & 22 & 31 & 62 \\
\hline Fat sensation & $31^{* *}$ & 24 & 1 & 10 & 27 & 49 & 98 & 24 & 13 & 0 & 13 & 27 & 34 & 65 \\
\hline \multicolumn{15}{|c|}{ Nutrients (in $100 \mathrm{~g}$ ) } \\
\hline Energy, kcal & $256^{* *}$ & 199 & 0 & 68 & 243 & 391 & 900 & 197 & 143 & 0 & 73 & 167 & 283 & 572 \\
\hline Protein, $\mathrm{g}$ & 7 & 7 & 0 & 1 & 5 & 10 & 38 & 7 & 7 & 0 & 2 & 5 & 10 & 39 \\
\hline Fat, $g$ & $14^{* *}$ & 19 & 0 & 0 & 5 & 21 & 100 & 8 & 9 & 0 & 1 & 6 & 13 & 55 \\
\hline Carbohydrates, $\mathrm{g}$ & 25 & 27 & 0 & 2 & 12 & 49 & 98 & 24 & 23 & 0 & 6 & 16 & 37 & 100 \\
\hline $\begin{array}{l}\text { Mono and } \\
\text { disaccharides, } g\end{array}$ & $13^{* *}$ & 18 & 0 & 1 & 4 & & 98 & 9 & 13 & 0 & 1 & 4 & 11 & 74 \\
\hline Dietary fiber, $g$ & 2 & 2 & 0 & 0 & 1 & 3 & 16 & 2 & 2 & 0 & 0 & 1 & 2 & 14 \\
\hline Sodium, mg & 316 & 479 & 0 & 10 & 133 & 492 & 5630 & 310 & 345 & 0 & 37 & 224 & 469 & 2387 \\
\hline
\end{tabular}

Significant different from Malaysian foods at ${ }^{*} p<0.05,{ }^{* *} p<0.01$ by student-t-test 
Dutch and Malaysian food taste clusters

Cluster analysis indicated six main clusters of Dutch foods and five main clusters of Malaysian foods based on taste and fat sensation intensities (Figure 2. and Figure 3.). Cluster 1 (23\% of total Dutch foods, $19 \%$ of total Malaysian foods) included more 'sweet and fatty foods' (i.e. confectionery and pastry), compared to the other clusters. Foods in this cluster had high sweet taste (44-51 point) and fat sensation (27-38 point) values. Cluster 2 (14\% of total Dutch foods, $15 \%$ of total Malaysian foods) contained foods with high 'sweet and sour' intensities (i.e. fruits and soft drinks), with a mean of 32-37 point in sweetness and 20-35 point in sourness. All 'neutral' foods without a predominant taste, were low in all 6 taste modalities (15 point) were categorized into cluster 3 ( $28 \%$ of total Dutch foods, $14 \%$ of total Malaysian foods). Cluster 4 ( $25 \%$ of total Dutch foods, $50 \%$ of total Malaysian foods) included more 'savory and fatty' foods, which were mostly the mixed dishes and cheeses. Foods in this cluster were dominant in umami (23-27 point), salt (31-42 point) and fat sensation tastes (33-47 point). The 'bitter' beverages (i.e. coffee) were grouped in cluster 5 (3\% of total Dutch foods, $2 \%$ of total Malaysian foods), with a mean of bitter intensity 43-46 point. Cluster 6, which contained 'fatty' foods was only formed in the Dutch database. A total of $7 \%$ of Dutch foods (including butter, margarine bread spread, cooking fats and oils) were grouped in this cluster. 


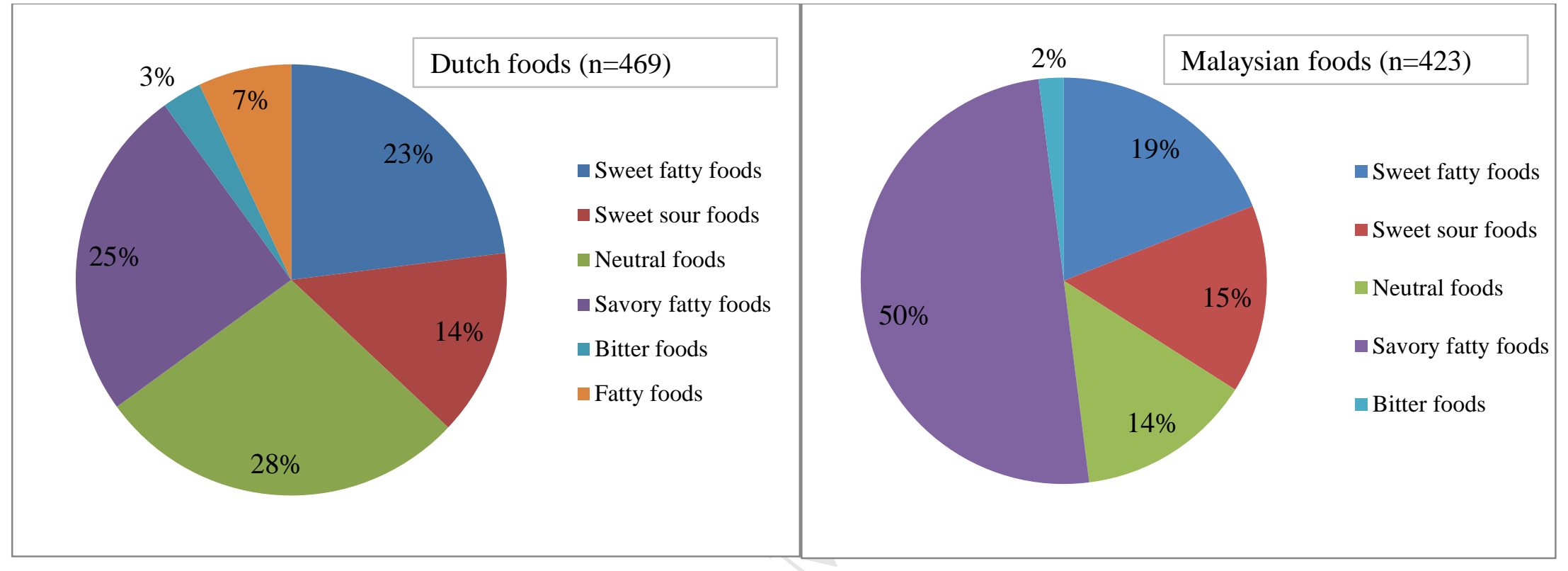

Figure 2. Proportion of each taste cluster to total i) Dutch and ii) Malaysian food items 


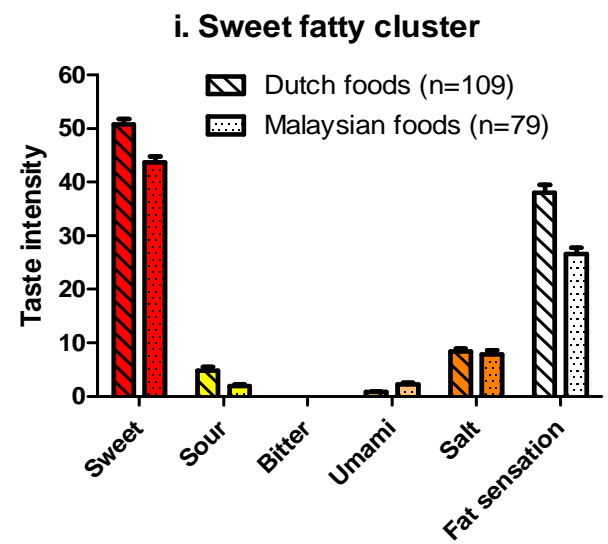

iv. Savory fatty cluster

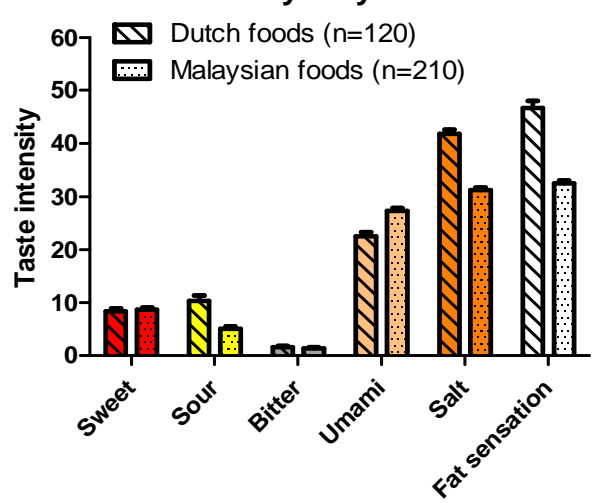

ii. Sweet sour cluster

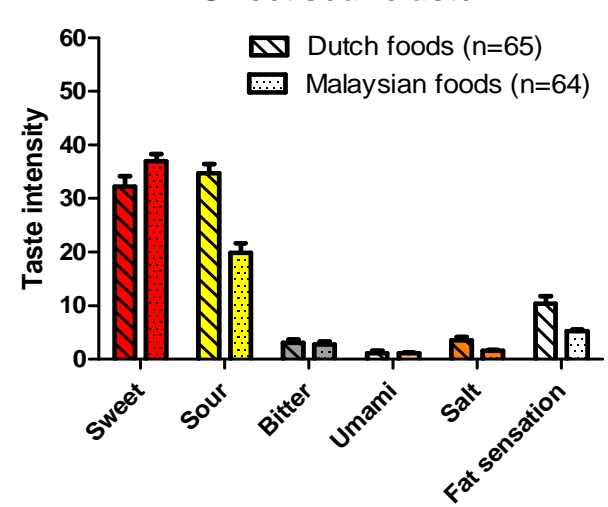

v. Bitter cluster

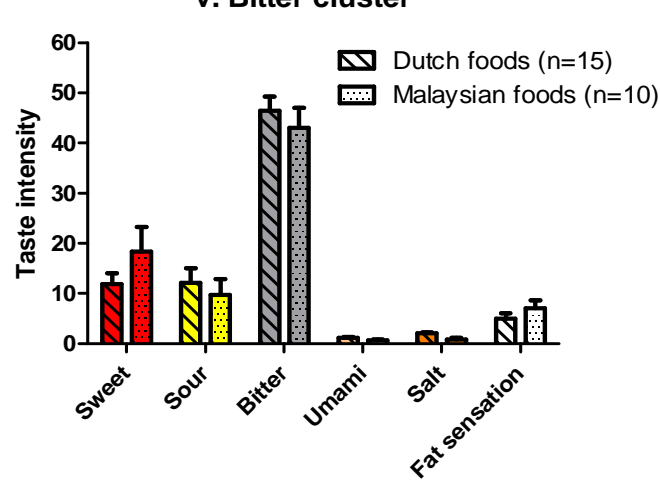

iii. Neutral cluster

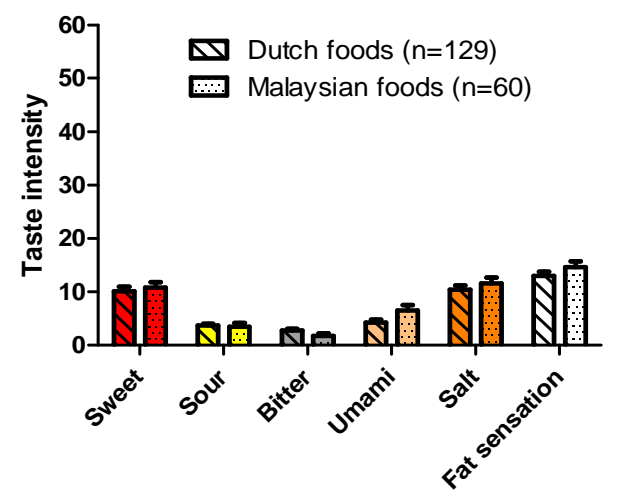

vi. Fatty cluster

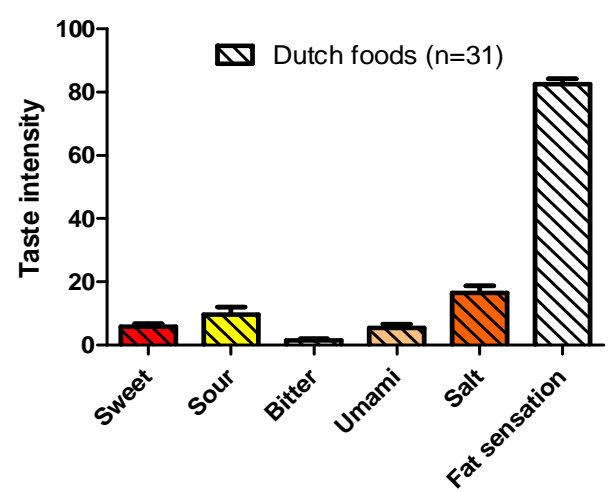

Figure 3. Mean ( \pm standard error) taste intensity of Dutch and Malaysian foods responses to i) sweet fatty cluster, ii) sweet sour cluster, iii) Neutral cluster, iv) savory fatty cluster, v) bitter cluster, vi) fatty cluster, measured using a 100 point $\operatorname{Spectrum}^{\mathrm{TM}}$ inspired rating scales by Dutch and Malaysian trained panels 
Association between taste intensity and nutrient content in Dutch and Malaysian foods

Table 3. and Figure 4. show the association between taste intensity and nutrient content in commonly consumed Dutch and Malaysian foods. Sweetness of Dutch or Malaysian foods was positively associated with their mono- and disaccharides and total carbohydrate content. Protein, fat and sodium content, to a smaller extent, were negatively associated with a Dutch or Malaysian food's sweet taste. Whilst, dietary fiber and energy (only marginally significant in Dutch foods) were not associated with sweet taste. Sweetness was best explained by its mono- and disaccharides content in Dutch $\left(\beta=0.89, p<0.001, \mathrm{R}^{2}=0.67\right)$ and Malaysian foods $(\beta=0.78$, $\left.p<0.001, \mathrm{R}^{2}=0.38\right)$.

Umami taste was positively associated most highly with its protein content in both Dutch $(\beta=0.8$, $\left.p<0.001, \mathrm{R}^{2}=0.29\right)$ and Malaysian foods $\left(\beta=1.0, p<0.001, \mathrm{R}^{2}=0.26\right)$, followed by sodium and fat contents. In contrast, carbohydrate, and mono- and disaccharides contents were inversely associated with a food's umami taste. Energy was not associated with umami taste.

In both Dutch and Malaysian foods, saltiness was positively associated with sodium, protein, fat and energy content, but negatively associated with carbohydrate and mono- and disaccharides content. No association was found between saltiness and dietary fiber. Saltiness was best explained by a food's sodium content in both the Dutch $\left(\beta=0.02, p<0.001, \mathrm{R}^{2}=0.48\right)$ and the Malaysian settings $\left(\beta=0.02, p<0.001, \mathrm{R}^{2}=0.27\right)$

A food's perceived fat sensation was reported to be most strongly associated with its fat content, in both Dutch $\left(\beta=0.93, p<0.001, \mathrm{R}^{2}=0.56\right)$ and Malaysian setting $\left(\beta=0.62, p<0.001, \mathrm{R}^{2}=0.17\right)$. To a lesser extent, fat sensation was also positively associated with its energy, protein and sodium contents. An inverse association was found between fat sensation and its carbohydrate content. 
390 Sour and bitter tastes were reported negatively associated with energy and most of the

391 macronutrient contents in both Dutch and Malaysian foods.

392 Associations of taste intensity and nutrient content were not different between the different

393 countries, except the fat sensation and its fat content (Figure 4.). Fat sensation of a Dutch food

394 was found to be stronger associated with its fat content ( $\mathrm{r}=0.76, \mathrm{CI}$ 0.86-1.0) compared to a

395 Malaysian food ( $\mathrm{r}=0.42$, CI 0.51-0.78), in a linear regression model.

396

397

398

399

400

401

402

403

404

405

406

407 
Table 3. Pearson correlation between taste and nutrients across Dutch and Malaysian food items

\begin{tabular}{|c|c|c|c|c|c|c|c|}
\hline & Energy & Protein & Fat & Carbohydrates & $\begin{array}{c}\text { Mono and } \\
\text { disaccharides }\end{array}$ & $\begin{array}{l}\text { Dietary } \\
\text { fiber }\end{array}$ & sodium \\
\hline \multicolumn{8}{|l|}{ i. Dutch } \\
\hline Sweet & $0.11^{*}$ & -0.36 & -0.14 & $0.54^{\mathrm{ab}}$ & $0.82^{\mathrm{ab}}$ & 0.03 & $-0.27^{\mathrm{a}}$ \\
\hline Sour & -0.36 & -0.20 & -0.19 & $-0.31^{\mathrm{ab}}$ & $-0.12^{a}$ & $-0.29^{\mathrm{a}}$ & $-0.03^{\mathrm{a}}$ \\
\hline Bitter & -0.20 & -0.19 & -0.12 & -0.16 & -0.07 & -0.04 & -0.13 \\
\hline Umami & -0.004 & 0.54 & $0.12^{\mathrm{a}}$ & -0.32 & -0.37 & $-0.21^{\mathrm{a}}$ & $0.58^{\mathrm{a}}$ \\
\hline Salt & 0.22 & 0.55 & $0.25^{\mathrm{a}}$ & $-0.13^{\mathrm{a}}$ & $-0.30^{\mathrm{a}}$ & -0.08 & $0.69^{\mathrm{ab}}$ \\
\hline Fat sensation & $0.58^{\mathrm{ab}}$ & $0.24^{\mathrm{a}}$ & $0.75^{\mathrm{ab}}$ & -0.18 & $-0.04^{\mathrm{a}}$ & $-0.28^{\mathrm{ab}}$ & 0.20 \\
\hline \multicolumn{8}{|l|}{ ii. Malaysian } \\
\hline Sweet & 0.04 & -0.37 & -0.17 & 0.33 & 0.62 & -0.04 & -0.41 \\
\hline Sour & -0.24 & -0.18 & -0.28 & -0.07 & 0.07 & -0.02 & -0.14 \\
\hline Bitter & -0.20 & -0.16 & -0.15 & -0.16 & -0.05 & $-0.12^{*}$ & $-0.10^{*}$ \\
\hline Umami & 0.04 & 0.51 & 0.27 & -0.32 & -0.45 & -0.05 & 0.47 \\
\hline Salt & 0.16 & 0.52 & 0.39 & -0.24 & -0.46 & 0.02 & 0.52 \\
\hline Fat sensation & 0.26 & 0.43 & 0.42 & $-0.10^{*}$ & -0.17 & -0.01 & 0.20 \\
\hline
\end{tabular}

409 All correlations (2-tailed) are significant at, ${ }^{*} p<0.05, p<0.01$, except sweet with dietary fiber, bitter with mono and disaccharides, 410 umami with energy, salt with dietary fiber for both Dutch and Malaysian foods; sour with sodium, bitter with dietary fiber, fat 411 sensation with mono and disaccharides for Dutch foods; sweet with energy, sour with carbohydrates, mono and disaccharides and 412 dietary fiber, umami with dietary fiber, fat sensation with dietary fiber for Malaysian foods

$413{ }^{a}$ Different from Malaysian foods by comparing the $95 \%$ confidence interval

$414{ }^{\mathrm{b}}$ Different from Malaysian foods by comparing the $99 \%$ confidence interval 
A) Sweetness vs. Mono- and dissachardies

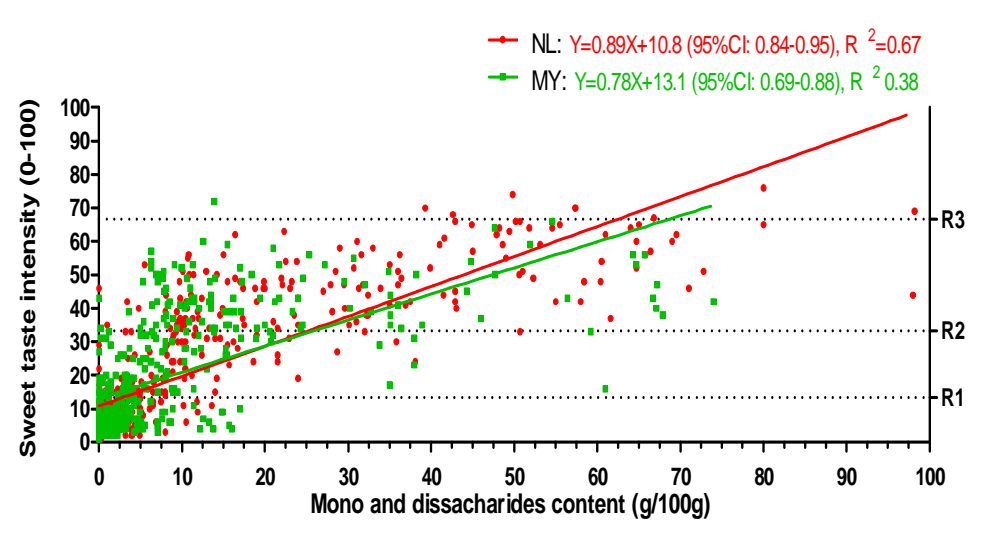

C) Saltiness vs. Sodium

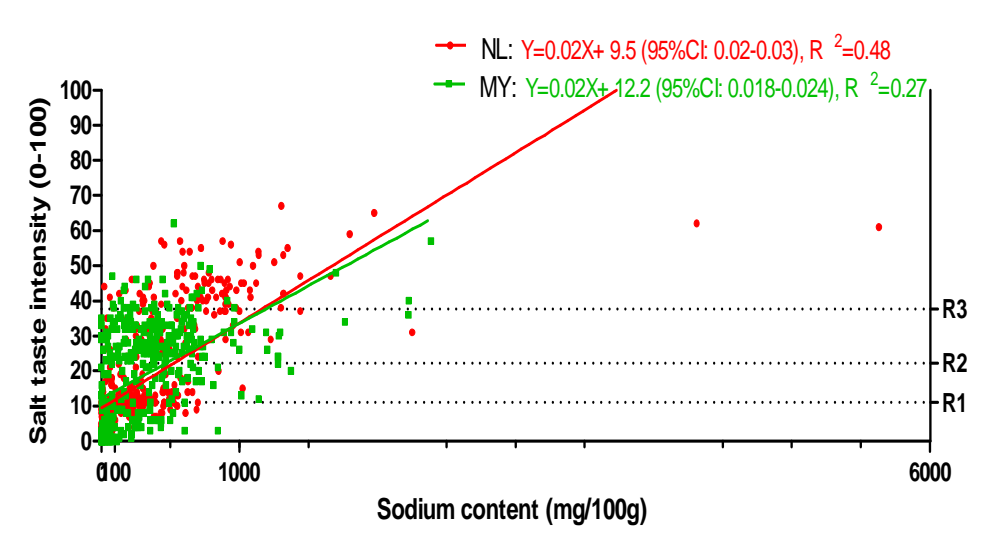

B) Umami vs. Protein

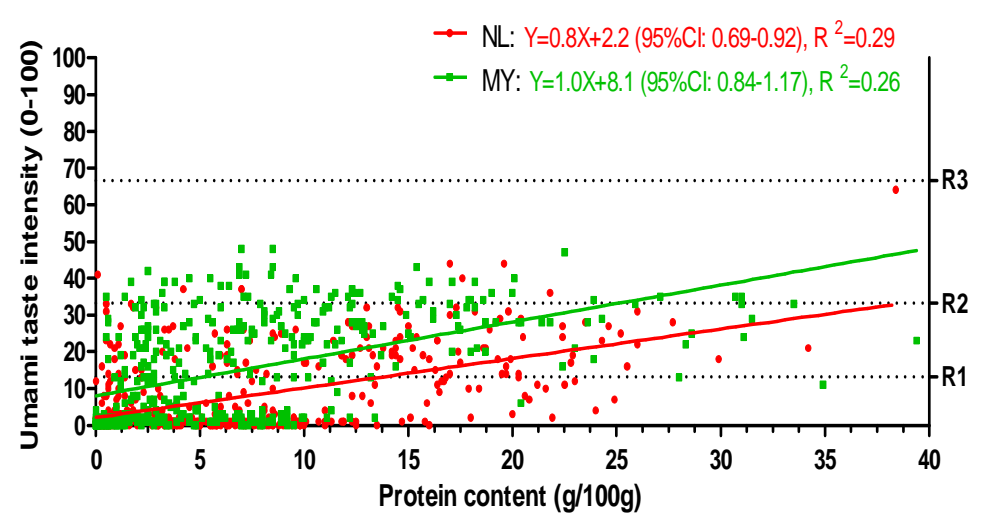

D) Fat sensation vs. Fat

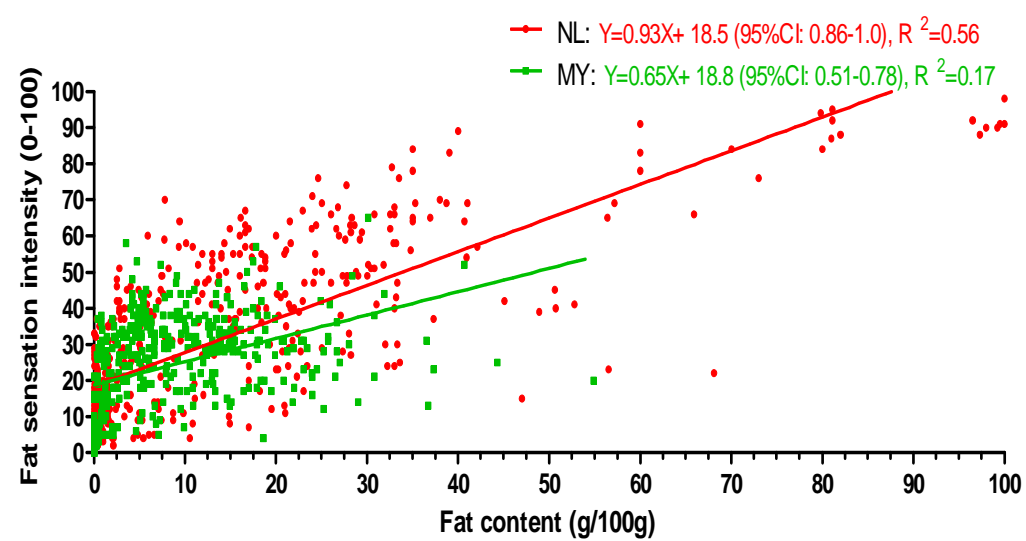

Figure 4. The associations between A) Sweet vs Mono and disaccharides, B) Umami vs protein, C) Saltiness vs sodium, D) Fat sensation vs Fat in Dutch and Malaysian foods. Red dot represents Dutch foods, whereas green dot represents Malaysian foods 
419

420

421

422

423

424

425

426

427

428

429

430

431

432

433

434

435

436

437

438

Figure 5. shows the biplot representations of the PCA with taste intensities as active variables and nutrient content as supplementary variables for both Dutch and Malaysian foods. As can be seen from the figures, similar taste and nutrient relationships were found in Dutch and Malaysian foods. The first component explained most of the variation, that is $40 \%$ in Dutch foods, and $50 \%$ in Malaysian foods. It was characterized by all tastes and related to all nutrients, except bitter, sour and dietary fiber. The second component (20\% in Dutch foods, $19 \%$ in Malaysian foods) was determined by sweet, bitter and sour tastes and related to mono- and disaccharides and carbohydrates. Bitter and sour were mainly differentiated by the $3^{\text {rd }}$ component (data not shown). The position of dietary fiber was close to the origin, indicating that it does not contribute much to the taste space.

Similarly, Pearson's correlations between tastes showed that saltiness, umami and fat sensation were positively correlated with one another, but negatively correlated to sweetness in both Dutch and Malaysian foods (all $p<0.01$ ) (data not shown). 


\section{i. Dutch foods}

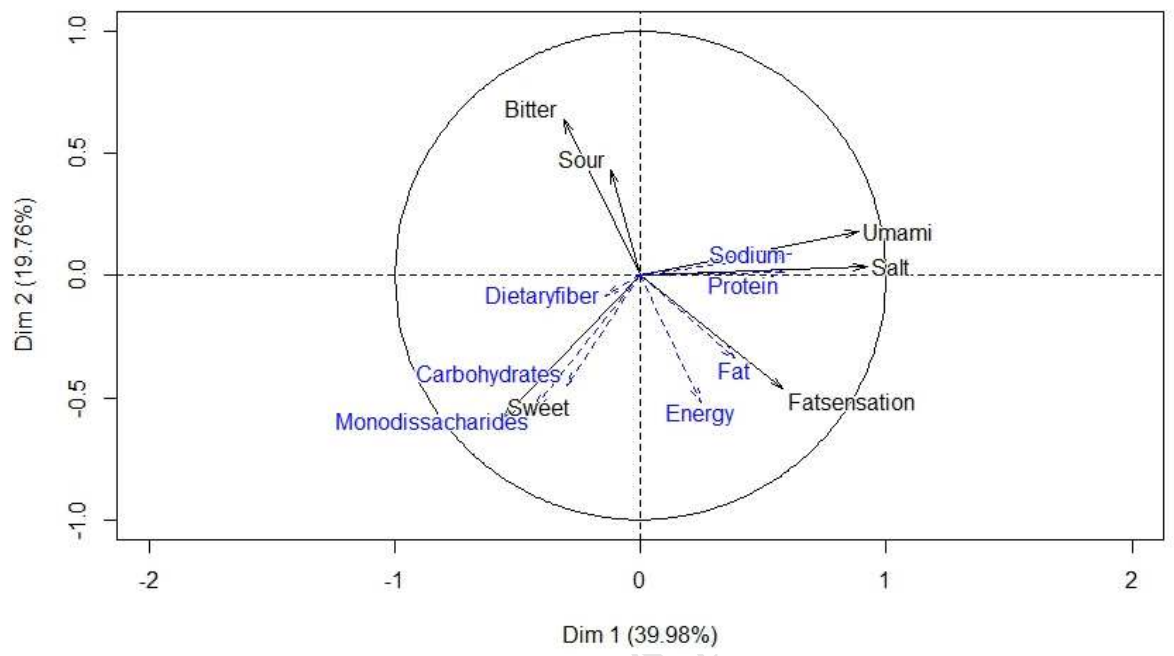

440

441

ii. Malaysian foods

442

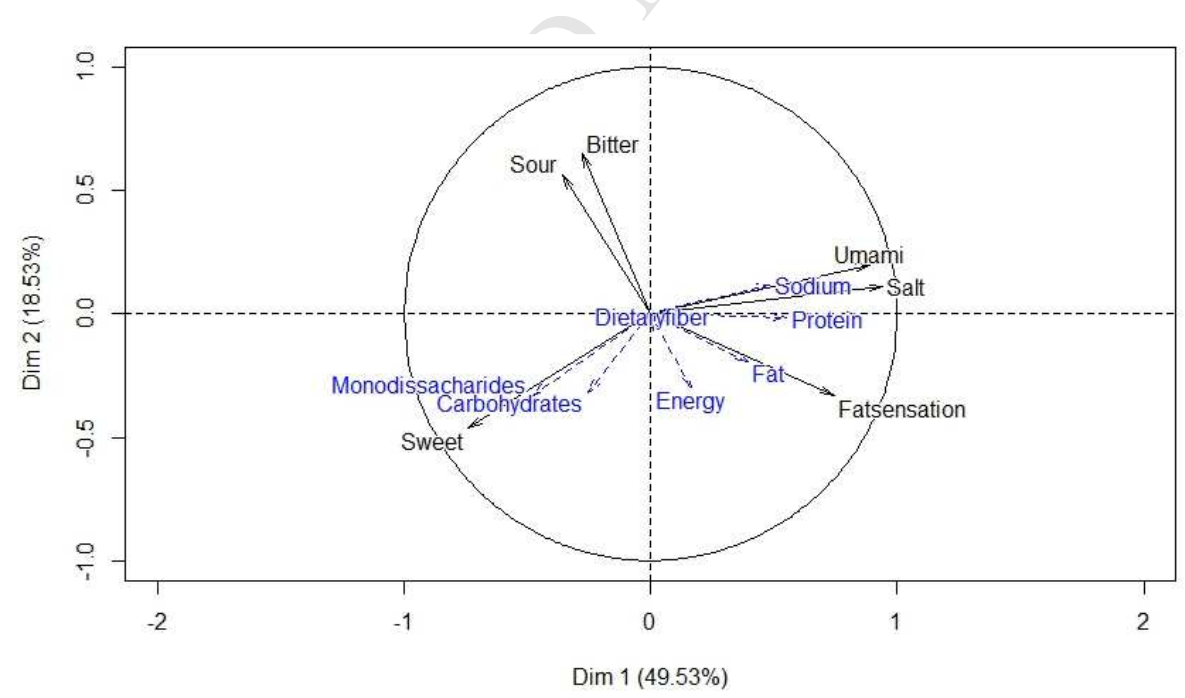

Figure 5. Biplot representations from covariance PCA of i) 469 Dutch and ii) 423 Malaysian foods means 
445

446

447

448

449

450

451

452

453

454

455

456

457

458

459

460

461

462

463

464

465

466

\section{Discussion}

This present study aimed to investigate the association between taste intensity and nutrient content in commonly consumed Dutch and Malaysian foods. As hypothesized, a positive association was found between sweetness and mono- and disaccharides, between umami and protein, between saltiness and sodium and between fat sensation and fat content. Energy content was positively associated with saltiness and fat sensation in both Dutch and Malaysian foods, but only marginally associated with sweetness of a Dutch food. The associations of taste intensity and nutrient content were not different between the different countries, except fat sensation and fat content. The basic taste-nutrient space was found as universal between commonly consumed Dutch and Malaysian foods.

Our findings are in agreement with earlier studies in the Netherlands (van Dongen, et al., 2012), Australia (Lease, et al., 2016) and the United States (van Langeveld, et al., 2017), all of which found that sweetness was positively associated with mono- and disaccharides, and salt and umami taste intensity were both positively associated with sodium and protein content.

Moreover, in current study, energy content was found to be associated with salt, umami and fat sensation, but not sweet taste. These results are in line with the previous works of Lease et al. (2016). They could be explained by the fact that energy density of foods is largely determined by their water and fat content (Drewnowski, 1998). Fat content was found positively correlated with saltiness, umami and fat sensation, but negatively correlated to sweetness.

Similar associations of taste intensity and nutrient content were found in Dutch and Malaysian foods, except the fat sensation and its fat content. Fat sensation of a Dutch food was stronger associated with its fat content compared to a Malaysian food. Also, a fat taste cluster was formed 
in Dutch foods but not in Malaysian foods. In current study, we used two different approaches in profiling fat products (i.e. butter, margarine, oils) in each country, that is according to how they were recorded in their local $24 \mathrm{hDR}$ dataset. For example, $100 \%$ oil, was tested separately as a single food in The Netherlands, whereas oil was prepared with other ingredients within a dish in Malaysia setting. The perceived range of fat sensation intensities was higher in Dutch foods (1-98 point) than in Malaysian foods (0- 65 point). And thus, by profiling fat products as a mixed dish, it possibly resulted in a weaker association of fat sensation and its fat content in Malaysian foods, as it may be suppressed by other tastes.

Another important finding was that the similar basic taste-nutrient space was found in both commonly consumed 469 Dutch and 423 Malaysian foods by comparing the taste-nutrient PCAs. In a total of 892 food items, we observed that only 3 identical commercially available products were tasted in both Dutch and Malaysian taste databases. These products were carbonated drink Coca-Cola ${ }^{\circledR}$ (regular), chocolate candy M\&M's® (with peanuts) and chocolate bar KitKat ${ }^{\circledR}$ (natural). Hence, in broad terms, the basic taste-nutrient space across two countries remained similar, even though analysis were performed on a wide variety of Dutch and Malaysian foods. A similar taste PCA observation was also reported in a recent paper of Dijon group in 2014 on 590 French foods (Martin, et al., 2014). Taken together, this indicates that the basic taste-nutrient space of commonly consumed foods around the world may be universal, without taking considerations of texture, flavors and odors.

It is remarkable to note that the average taste profiles of commonly consumed foods as observed for the Netherlands and Malaysia are in some aspects very similar to the taste profiles of foods in France (Martin, et al., 2014) and Australia (Lease, et al., 2016), which also used the 100-point Spectrum $^{\mathrm{TM}}$ scales. For example, the average perceived saltiness intensity in the Dutch (17-point) 
and Malaysian (19-point) foods are almost equal to those in French (19-point) and Australian (17-point) foods. However, the average sweetness intensity in Australian foods (28-point) is higher than those in the Dutch (22-point), Malaysian (20-point) and French (17-point) foods. These discrepancies could be explained by the tested foods in the study of Lease et al (2016) were aimed for Australian children, aged 2-16 years. In which, previous studies have suggested that younger children heightened preference for sweet than did adolescents, and adolescents likewise had a higher sweet preference than did adults (de Graaf \& Zandstra, 1999; Desor \& Beauchamp, 1987).

On the other hand, average umami taste intensity in Malaysian foods is higher (15-point) compared to the foods in the Netherlands (8-point), France (8-point) and Australia (8-point). These differences are likely to be related to food pattern variations in the different cultural contexts. Asian foods are found to contain ingredients with high amounts of umami substances (i.e., fermented and dried seafood, mushrooms, beans and grains), and to undergo preparations that enhance the release of umami substances by adding fish sauce or soy sauce (Hajeb \& Jinap, 2015). It is further supported by the findings of high free glutamic acid content in local Malaysian condiments, which are commonly used in routine cooking. For instance, fish sauce $(B u d u)$, shrimp paste (Belacan), fermented soy bean paste (Taucu) and soy sauce are rich in umami, with a free glutamic acid of 948-4207mg per 100g (Jinap, et al., 2010; Khairunnisak, Azizah, Jinap, \& Nurul Izzah, 2009). In present study, a higher amount of 'savory fatty' dishes were reported in commonly consumed Malaysian foods than Dutch foods. Therefore, we also expected a higher umami taste in Malaysian foods compared to Dutch foods.

The present study were set up in controlled sensory laboratories in both the Netherlands and Malaysia, which could be differed than the natural food eating environment. Nevertheless, the 
natural eating behaviors (including textural eating rate and bite sizes) of our trained panels were

514 not standardized or controlled, in which they were encouraged to follow their own eating habits

515 in each taste evaluation sessions. Thus, it is conceivable that our food taste profiles were

516 adequately reflected the real eating taste perception of a population compared to hedonic taste

517 liking of consumers, and thus it can be further translated into a population's taste database. 
Our findings suggest that sweetness, umami, saltiness and fat sensation can signal the presence of nutrients, in particular mono- and disaccharides, protein, sodium and fat content in commonly consumed Dutch and Malaysian foods. The associations of taste intensity and nutrient content were not different between the different countries, except the fat sensation and its fat content. Basic taste-nutrient space was found as universal between commonly consumed Dutch and Malaysian foods.

The results of this work demonstrated that the Dutch and Malaysian food taste databases, complied by two equally-trained panels, allowed a valid comparison of taste intensity and nutrient content relationships in both settings. Since the food selections were based on the nationwide food consumption surveys in both countries, the associations between taste intensity and nutrient content can be generalized to foods that are eaten on a daily basis in The Netherlands and Malaysia. Further research should combine the taste databases with consumption data to better understand the taste intake patterns in general population diet.

\section{Acknowledgements}

The authors thank the Director General of Health, Malaysia for his permission to use the data from Malaysian Adults Nutrition Surveys (MANS) 2014 and to publish this paper. The authors would like to special thank Hao Zi Teo and Dr. Ee Siong Tee for their advice on the selection of frequently consumed Malaysian foods. The authors would also like to acknowledge Marlot Smulders, Eric Benyon, Petroula Gogoulou, Sandra Scheffel, Martha van der Velde, Delphine Dupuis, Chloé Parizel, Zahabia Jivaji, Desiree Lucassen, Janneke Schultink, Renske Geers, Vera 
540

541

542

543

544

545

546

547

548

549

550

551

552

553

554

555

556

557

van Stokkom, Jolinde Sauren, Aisyah Saifulzaman, Kian Aun Chang, Benjamin Lee Chuin Hern, Linda Klarenberg, and Anke Zeelenberg for their assistance during the data collection. The author would also like to thank Taylor's University for providing the funding of this project under the Fundamental Research Grant Scheme (Research Grant No.

FRGS/1/2013/SS03/TAYLOR/03/1). This research work was supported by Wageningen University and Taylor's University through its PhD Fellowship program.

\section{Funding}

This work was supported by PhD Fellowship program of Taylor's University; and collaborative agreement between the chair of Sensory Science and Eating Behavior, Department of Human Nutrition, Wageningen University; the chair of Marketing and Consumer Behavior; Subdepartment Business, Consumer and Competence Studies, Wageningen University; Consumer Science and Health group, Wageningen Food \& Biobased Research on the one hand and Danone Nutricia Research; Heineken Research; Friesland Campina Research; and Unilever R\&D Vlaardingen on the other hand.

\section{Conflict of interest}

None of the authors reported a conflict of interest related to the study. 


\section{References}

Ahn, Y.-Y., Ahnert, S. E., Bagrow, J. P., \& Barabási, A.-L. (2011). Flavor network and the principles of food pairing. Scientific Reports, 1, 196.

Bolhuis, D. P., Lakemond, C. M. M., de Wijk, R. A., Luning, P. A., \& de Graaf, C. (2011). Both longer oral sensory exposure to and higher intensity of saltiness decrease ad libitum food intake in healthy normal-weight men. The Journal of Nutrition, 141, 2242-2248.

Cox, D. N., Hendrie, G. A., \& Carty, D. (2016). Sensitivity, hedonics and preferences for basic tastes and fat amongst adults and children of differing weight status: A comprehensive review. Food Quality and Preference, 48, 359-367.

de Graaf, C., \& Kok, F. J. (2010). Slow food, fast food and the control of food intake. Nature Reviews Endocrinology, 6, 290-293.

de Graaf, C., \& Zandstra, E. H. (1999). Sweetness intensity and pleasantness in children, adolescents, and adults. Physiology \& behavior, 67, 513-520.

Desor, J. A., \& Beauchamp, G. K. (1987). Longitudinal changes in sweet preferences in humans. Physiology \& behavior, 39, 639-641.

Drewnowski, A. (1997). Taste preferences and food intake. Annual Review of Nutrition, 17, $237-$ 253.

Drewnowski, A. (1998). Energy density, palatability, and satiety: implications for weight control. Nutrition Reviews, 56, 347-353. 
Food composition guide Singapore. (2011). Energy and nutrient composition of food. In. Singpore: Health Promotion Board.

Hajeb, P., \& Jinap, S. (2015). Umami taste components and their sources in Asian foods. Critical Reviews in Food Science and Nutrition, 55, 778-791.

Henderson, H. H. F. (1999). Het nieuwe kookboek (The new Dutch cookbook). Utrecht, The Netherlands: Kosmos.

Institute for Public Health. (2014). National Health and Morbidity Survey 2014 : Malaysia Adult Nutrition Survey (MANS). In Vol. III : Food Consumption Statistics of Malaysia (pp. 1143).

Jinap, S., Ilya-Nur, A. R., Tang, S. C., Hajeb, P., Shahrim, K., \& Khairunnisak, M. (2010). Sensory attributes of dishes containing shrimp paste with different concentrations of glutamate and 5'-nucleotides. Appetite, 55, 238-244.

Khairunnisak, M., Azizah, A. H., Jinap, S., \& Nurul Izzah, A. (2009). Monitoring of free glutamic acid in Malaysian processed foods, dishes and condiments. Food Additives \& Contaminants. Part A Chemistry, Analysis, Control, Exposure \& Risk Assessment, 26, 419-426.

Lease, H., Hendrie, G. A., Poelman, A. A. M., Delahunty, C., \& Cox, D. N. (2016). A SensoryDiet database: a tool to characterise the sensory qualities of diets. Food Quality and Preference, 49, 20-32. 
Martin, C., Tavares, J., Schwartz, C., Nicklaus, S., \& Issanchou, S. (2009). The taste of infants' diet: From formula milks to baby fruits \& vegetables. In 8th Pangborn Sensory Science Symposium. Florence, Italy.

Martin, C., Visalli, M., Lange, C., Schlich, P., \& Issanchou, S. (2014). Creation of a food taste database using an in-home "taste" profile method. Food Quality and Preference, 36, 7080.

McCrickerd, K., \& Forde, C. G. (2016). Sensory influences on food intake control: moving beyond palatability. Obesity Reviews, 17, 18-29.

Muñoz., A., \& Civille, G. (1992). The spectrum descriptive analysis method. Manual on descriptive analysis testing for sensory evaluation, 22-34.

Poulain, J.-P., Tibère, L., Laporte, C., \& Mognard, E. (2014). Malaysian food barometer: Taylor's Press.

Prescott, J. (1998). Comparisons of taste perceptions and preferences of Japanese and Australian consumers: overview and implications for cross-cultural sensory research. Food Quality and Preference, 9, 393-402.

Rozin, P. (1996). The socio-cultural context of eating and food choice. In H. L. Meiselman \& H. J. H. MacFie (Eds.), Food Choice, Acceptance and Consumption (pp. 83-104). Boston, MA: Springer US.

Rozin, P., \& Vollmecke, T. A. (1986). Food likes and dislikes. Annual Review of Nutrition, 6, 433-456. 
Tee, E., Noor, M. I., Azudin, M. N., \& Idris, K. (1997). Nutrient composition of Malaysian foods: Institute for Medical Research.

Temussi, P. A. (2009). Sweet, bitter and umami receptors: a complex relationship. Trends in Biochemical Sciences, 34, 296-302.

Teo, P.S., van Langeveld, A.W.B., Pol, K., Siebelink, E., de Graaf, C., Martin, C., Issanchou, S., Yan, S.W., Mars, M (2017). Training of a Dutch and Malaysian sensory panel to assess intensities of basic tastes and fat sensation of commonly consumed foods. Food Quality and Preference, under review.

United States Department of Agriculture, \& Agricultural Research Service. (2008). USDA national nutrient database for standard reference, release 21. In. Nutrient Data Laboratory Home Page.

van Dongen, M. V., van den Berg, M. C., Vink, N., Kok, F. J., \& de Graaf, C. (2012). Tastenutrient relationships in commonly consumed foods. British Journal of Nutrition, 108, $140-147$.

van Langeveld, A. W. B., Gibbons, S., Koelliker, Y., Civille, G. V., de Vries, J. H. M., de Graaf, C., \& Mars, M. (2017). The relationship between taste and nutrient content in commercially available foods from the United States. Food Quality and Preference, 57, $1-7$.

Van Rossum, C., Fransen, H., Verkaik-Kloosterman, J., Buurma-Rethans, E., \& Ocké, M. (2011). Dutch National Food Consumption Survey 2007-2010: diet of children and adults aged 7 to 69 years. In: RIVM rapport 350050006. 
Ward, J. H. (1963). Hierarchical grouping to optimize an objective function. Journal of the American Statistical Association, 58, 236-244.

Weijzen, P. L. G., Smeets, P. A. M., \& de Graaf, C. (2009). Sip size of orangeade: effects on intake and sensory-specific satiation. British Journal of Nutrition, 102, 1091-1097.

Westenbrink, S., Jansen-van der Vliet, M., Castenmiller, J., Grit, C., \& Verheijen, P. (2016). NEVO-online 2016: background information. In.

World Health Organization. (2013). Global action plan for the prevention and control of noncommunicable diseases 2013-2020. In.

Yarmolinsky, D. A., Zuker, C. S., \& Ryba, N. J. P. (2009). Common sense about taste: from mammals to insects. Cell, $139,234-244$.

Zandstra, E. H., Lion, R., \& Newson, R. S. (2016). Salt reduction: Moving from consumer awareness to action. Food Quality and Preference, 48, 376-381. 


\section{Supplemental files}

Table S1. Taste database of 469 Dutch foods. For each food evaluated: Cluster (result of taste classification), number of evaluations $(\mathrm{n})$, mean $(\mathrm{m})$ and standard error (SE) for the five basic tastes and fat sensation

\begin{tabular}{|c|c|c|c|c|c|c|c|c|c|c|c|c|c|c|}
\hline \multirow[t]{2}{*}{ Food } & \multirow[t]{2}{*}{ Cluster } & \multirow[t]{2}{*}{$\mathrm{n}$} & \multicolumn{2}{|c|}{ Sweet } & \multicolumn{2}{|c|}{ Sour } & \multicolumn{2}{|c|}{ Bitter } & \multicolumn{2}{|c|}{ Umami } & \multicolumn{2}{|c|}{ Salt } & \multicolumn{2}{|c|}{ Fat } \\
\hline & & & $\mathrm{m}$ & SE & $\mathrm{m}$ & SE & $\mathrm{m}$ & $\mathrm{SE}$ & $\mathrm{m}$ & SE & $\mathrm{m}$ & $\mathrm{SE}$ & $\mathrm{m}$ & $\mathrm{SE}$ \\
\hline Almond paste filled tarts average & Sweet Fatty & 12 & 56 & 3 & 1 & 1 & 2 & 1 & 1 & 1 & 9 & 3 & 37 & 3 \\
\hline Apple pie Dutch with shortbread with margarine & Sweet Fatty & 10 & 54 & 3 & 14 & 3 & 1 & 0 & 2 & 1 & 11 & 3 & 47 & 4 \\
\hline Apple sauce tinned & Sweet Sour & 12 & 46 & 4 & 21 & 2 & 0 & 0 & 2 & 1 & 2 & 1 & 13 & 3 \\
\hline Apple turnover & Sweet Fatty & 8 & 62 & 5 & 6 & 2 & 1 & 0 & 1 & 0 & 12 & 4 & 33 & 6 \\
\hline Apple with skin average & Sweet Sour & 12 & 22 & 3 & 40 & 4 & 1 & 0 & 1 & 1 & 1 & 0 & 3 & 1 \\
\hline Apple without skin average & Sweet Sour & 12 & 20 & 3 & 38 & 3 & 2 & 1 & 0 & 0 & 1 & 0 & 4 & 1 \\
\hline Bacon lean smoked fried in non-stick coating pan & Savory fatty & 7 & 6 & 3 & 6 & 2 & 0 & 0 & 15 & 5 & 67 & 3 & 61 & 7 \\
\hline Bacon rasher fried in non-stick coating pan & Fatty & 9 & 4 & 2 & 3 & 2 & 4 & 4 & 9 & 3 & 21 & 4 & 61 & 6 \\
\hline Bacon rashers streaky & Savory fatty & 7 & 4 & 2 & 6 & 4 & 0 & 0 & 21 & 8 & 53 & 4 & 76 & 4 \\
\hline Baguette brown & Neutral & 9 & 6 & 2 & 2 & 1 & 1 & 1 & 0 & 0 & 17 & 2 & 10 & 2 \\
\hline Baguette white & Neutral & 12 & 8 & 1 & 3 & 1 & 1 & 0 & 0 & 0 & 18 & 3 & 12 & 2 \\
\hline Banana & Neutral & 12 & 29 & 2 & 2 & 1 & 1 & 1 & 1 & 0 & 1 & 1 & 24 & 5 \\
\hline Bean sprouts boiled & Neutral & 7 & 8 & 3 & 6 & 3 & 11 & 3 & 3 & 1 & 2 & 1 & 6 & 4 \\
\hline Beans baked in tomato sauce tinned & Neutral & 9 & 18 & 2 & 6 & 2 & 1 & 1 & 16 & 4 & 28 & 5 & 17 & 2 \\
\hline Beans brown tinned & Neutral & 9 & 8 & 2 & 1 & 0 & 2 & 1 & 9 & 2 & 19 & 3 & 13 & 3 \\
\hline Beans French boiled & Neutral & 10 & 9 & 1 & 3 & 2 & 2 & 1 & 4 & 2 & 4 & 1 & 9 & 3 \\
\hline Beans French tinned & Neutral & 7 & 7 & 3 & 3 & 2 & 3 & 2 & 6 & 3 & 14 & 3 & 11 & 4 \\
\hline Beef olives raw & Savory fatty & 10 & 6 & 2 & 8 & 2 & 1 & 0 & 19 & 6 & 47 & 5 & 55 & 6 \\
\hline Beef rump steak (pan-fried) & Neutral & 10 & 5 & 1 & 7 & 2 & 1 & 0 & 18 & 5 & 17 & 4 & 24 & 2 \\
\hline Beef smoke-dried & Savory fatty & 12 & 2 & 1 & 8 & 2 & 0 & 0 & 19 & 4 & 59 & 4 & 38 & 6 \\
\hline Beef steak tartare (pan-fried) & Neutral & 10 & 4 & 1 & 5 & 2 & 1 & 0 & 10 & 3 & 15 & 2 & 31 & 5 \\
\hline
\end{tabular}




\begin{tabular}{|c|c|c|c|c|c|c|c|c|c|c|c|c|c|c|}
\hline \multirow[t]{2}{*}{ Food } & \multirow[t]{2}{*}{ Cluster } & \multirow[t]{2}{*}{$\mathrm{n}$} & \multicolumn{2}{|c|}{ Sweet } & \multicolumn{2}{|c|}{ Sour } & \multicolumn{2}{|c|}{ Bitter } & \multicolumn{2}{|c|}{ Umami } & \multicolumn{2}{|c|}{ Salt } & \multicolumn{2}{|c|}{ Fat } \\
\hline & & & $\mathrm{m}$ & SE & $\mathrm{m}$ & SE & $\mathrm{m}$ & SE & $\mathrm{m}$ & SE & $\mathrm{m}$ & SE & $\mathrm{m}$ & $\mathrm{SE}$ \\
\hline Beef steak tartare spiced filet americ & Savory fatty & 9 & 8 & 2 & 5 & 2 & 0 & 0 & 19 & 7 & 41 & 2 & 51 & 5 \\
\hline Beer $>7$ vol $\%$ alcohol & Bitter & 13 & 7 & 2 & 20 & 6 & 53 & 5 & 2 & 1 & 2 & 1 & 1 & 1 \\
\hline Beer pilsner & Bitter & 13 & 6 & 1 & 17 & 6 & 55 & 6 & 1 & 1 & 1 & 1 & 1 & 1 \\
\hline Biscuit brown/wholemeal & Neutral & 12 & 24 & 2 & 1 & 1 & 1 & 1 & 0 & 0 & 10 & 3 & 8 & 1 \\
\hline Biscuit chocolate & Sweet Fatty & 8 & 35 & 3 & 1 & 1 & 8 & 3 & 0 & 0 & 13 & 4 & 23 & 3 \\
\hline Biscuit chocolate coated Chocoprins & Sweet Fatty & 7 & 59 & 3 & 1 & 0 & 4 & 2 & 1 & 0 & 13 & 5 & 41 & 3 \\
\hline Biscuit Dutch Amaretti Bitterkoekjes & Sweet Fatty & 9 & 50 & 5 & 1 & 0 & 12 & 5 & 1 & 1 & 10 & 4 & 27 & 5 \\
\hline Biscuit Dutch shortbread spritsstukken & Sweet Fatty & 8 & 38 & 2 & 1 & 1 & 1 & 1 & 0 & 0 & 15 & 4 & 27 & 6 \\
\hline Biscuit filled Prince & Sweet Fatty & 7 & 47 & 3 & 1 & 1 & 0 & 0 & 0 & 0 & 13 & 5 & 24 & 4 \\
\hline Biscuit fortified with currants LigaEvergreen & Neutral & 8 & 36 & 3 & 3 & 2 & 1 & 0 & 1 & 1 & 13 & 3 & 11 & 2 \\
\hline Biscuit fortified Liga Fruitkick & Sweet Sour & 9 & 33 & 2 & 18 & 3 & 0 & 0 & 0 & 0 & 10 & 4 & 16 & 2 \\
\hline Biscuit fortified Liga Milkbreak & Sweet Fatty & 8 & 36 & 2 & 2 & 2 & 1 & 1 & 1 & 0 & 14 & 4 & 20 & 3 \\
\hline Biscuit fruit & Neutral & 12 & 30 & 2 & 5 & 1 & 1 & 0 & 1 & 0 & 7 & 2 & 12 & 2 \\
\hline Biscuit salted average & Neutral & 12 & 6 & 2 & 1 & 1 & 0 & 0 & 4 & 2 & 45 & 2 & 17 & 3 \\
\hline Biscuit savory Sultana & Savory fatty & 7 & 10 & 3 & 4 & 2 & 1 & 0 & 24 & 9 & 42 & 4 & 15 & 3 \\
\hline Biscuit shortbread Bastogne & Sweet Fatty & 8 & 51 & 4 & 0 & 0 & 3 & 2 & 2 & 1 & 11 & 5 & 23 & 4 \\
\hline Biscuit spiced Speculaas & Sweet Fatty & 11 & 39 & 3 & 1 & 1 & 1 & 1 & 1 & 0 & 11 & 3 & 13 & 3 \\
\hline Biscuit spiced Speculaas with almond paste & Sweet Fatty & 6 & 60 & 4 & 1 & 1 & 3 & 2 & 0 & 0 & 15 & 6 & 47 & 6 \\
\hline Biscuit sponge fingers & Sweet Fatty & 9 & 51 & 4 & 0 & 0 & 0 & 0 & 0 & 0 & 7 & 3 & 11 & 3 \\
\hline Biscuit sweet & Neutral & 12 & 24 & 1 & 1 & 0 & 0 & 0 & 0 & 0 & 8 & 2 & 8 & 1 \\
\hline Biscuits \& snacks cheesy averaged & Savory fatty & 8 & 6 & 2 & 2 & 1 & 0 & 0 & 8 & 4 & 41 & 4 & 24 & 4 \\
\hline Biscuits averaged & Neutral & 11 & 27 & 3 & 1 & 1 & 1 & 0 & 1 & 0 & 11 & 3 & 12 & 2 \\
\hline Biscuits Dutch krakeling & Sweet Fatty & 8 & 53 & 3 & 0 & 0 & 0 & 0 & 0 & 0 & 11 & 4 & 24 & 5 \\
\hline Boiled sweets & Sweet Sour & 12 & 46 & 3 & 19 & 4 & 2 & 1 & 0 & 0 & 2 & 1 & 7 & 3 \\
\hline Bread Blue Band Goede Start white bread & Neutral & 11 & 5 & 1 & 2 & 1 & 1 & 1 & 0 & 0 & 11 & 2 & 9 & 2 \\
\hline Bread brown wheat & Neutral & 11 & 4 & 1 & 2 & 1 & 2 & 1 & 0 & 0 & 12 & 2 & 8 & 1 \\
\hline Bread ciabatta no filling (warm) & Neutral & 8 & 6 & 1 & 3 & 1 & 1 & 1 & 1 & 1 & 18 & 2 & 8 & 1 \\
\hline Bread corn with sunflower seeds & Neutral & 11 & 7 & 2 & 1 & 1 & 1 & 1 & 1 & 1 & 11 & 3 & 11 & 3 \\
\hline Bread multigrain average with seeds & Neutral & 11 & 4 & 1 & 2 & 1 & 2 & 1 & 1 & 0 & 13 & 2 & 9 & 2 \\
\hline
\end{tabular}




\begin{tabular}{|c|c|c|c|c|c|c|c|c|c|c|c|c|c|c|}
\hline \multirow[t]{2}{*}{ Food } & \multirow[t]{2}{*}{ Cluster } & \multirow[t]{2}{*}{$\mathrm{n}$} & \multicolumn{2}{|c|}{ Sweet } & \multicolumn{2}{|c|}{ Sour } & \multicolumn{2}{|c|}{ Bitter } & \multicolumn{2}{|c|}{ Umami } & \multicolumn{2}{|c|}{ Salt } & \multicolumn{2}{|c|}{ Fat } \\
\hline & & & $\mathrm{m}$ & $\mathrm{SE}$ & $\mathrm{m}$ & SE & $\mathrm{m}$ & SE & $\mathrm{m}$ & SE & $\mathrm{m}$ & SE & $\mathrm{m}$ & $\mathrm{SE}$ \\
\hline Bread pita white (warm) & Neutral & 10 & 7 & 2 & 2 & 1 & 1 & 0 & 3 & 2 & 13 & 3 & 14 & 3 \\
\hline Bread stuffed Bapao meat & Savory fatty & 9 & 18 & 2 & 6 & 2 & 0 & 0 & 25 & 9 & 35 & 5 & 36 & 4 \\
\hline Bread Tijger white & Neutral & 10 & 7 & 2 & 2 & 1 & 1 & 1 & 0 & 0 & 13 & 3 & 12 & 4 \\
\hline Bread wheat malt Tarvo & Neutral & 10 & 5 & 1 & 3 & 1 & 2 & 1 & 0 & 0 & 12 & 3 & 8 & 2 \\
\hline Bread white milk based & Neutral & 11 & 7 & 2 & 2 & 1 & 0 & 0 & 0 & 0 & 11 & 2 & 12 & 2 \\
\hline Bread white Turkish (warm) & Neutral & 9 & 5 & 1 & 2 & 1 & 1 & 1 & 1 & 0 & 14 & 2 & 11 & 2 \\
\hline Bread white water based & Neutral & 11 & 5 & 1 & 2 & 1 & 2 & 1 & 0 & 0 & 11 & 2 & 9 & 2 \\
\hline Bread white with sugar Suikerbrood & Sweet Fatty & 11 & 51 & 4 & 3 & 2 & 1 & 1 & 0 & 0 & 12 & 3 & 37 & 6 \\
\hline Bread wholemeal average & Neutral & 11 & 4 & 1 & 3 & 1 & 2 & 1 & 1 & 0 & 11 & 2 & 7 & 1 \\
\hline Bread wholemeal with seeds & Neutral & 10 & 5 & 2 & 5 & 2 & 4 & 2 & 1 & 1 & 14 & 3 & 9 & 3 \\
\hline Bread wholemeal with sunflower seeds & Neutral & 11 & 4 & 1 & 2 & 1 & 4 & 2 & 1 & 1 & 14 & 2 & 9 & 2 \\
\hline Breadsticks & Neutral & 8 & 5 & 1 & 1 & 0 & 1 & 0 & 0 & 0 & 20 & 2 & 5 & 1 \\
\hline $\begin{array}{l}\text { Breakfast cereal All-Bran Fruit and Fibre } \\
\text { Breakfast cereal Brinta prepared with semi- }\end{array}$ & Neutral & 11 & 19 & 2 & 2 & 1 & 1 & 1 & 1 & 0 & 10 & 2 & 5 & 1 \\
\hline skimmed milk & Neutral & 7 & 6 & 2 & 1 & 1 & 2 & 1 & 1 & 1 & 6 & 2 & 20 & 5 \\
\hline Breakfast cereal Cornflakes Kellogg's & Neutral & 12 & 14 & 2 & 2 & 1 & 1 & 1 & 2 & 1 & 9 & 2 & 5 & 1 \\
\hline Breakfast drink Goede Morgen original & Sweet Sour & 9 & 30 & 4 & 24 & 2 & 1 & 1 & 1 & 1 & 3 & 2 & 30 & 3 \\
\hline Breakfast drink HeroFruitontbijt p 100ml & Sweet Sour & 8 & 39 & 4 & 32 & 3 & 1 & 0 & 0 & 0 & 2 & 2 & 11 & 3 \\
\hline Breakfast prod Coco Pops Kellogg's & Sweet Fatty & 8 & 41 & 4 & 1 & 0 & 5 & 2 & 0 & 0 & 12 & 4 & 13 & 4 \\
\hline Broccoli boiled & Neutral & 10 & 6 & 1 & 5 & 2 & 4 & 1 & 6 & 2 & 4 & 1 & 8 & 3 \\
\hline Brussel sprouts boiled & Neutral & 9 & 8 & 2 & 2 & 1 & 19 & 4 & 9 & 4 & 5 & 2 & 7 & 2 \\
\hline Bun currant/raisin & Neutral & 12 & 26 & 3 & 7 & 2 & 2 & 1 & 1 & 0 & 11 & 2 & 18 & 3 \\
\hline Bun wholemeal with muesli & Neutral & 11 & 23 & 3 & 6 & 2 & 1 & 0 & 1 & 1 & 12 & 3 & 14 & 2 \\
\hline Butter salted & Fatty & 8 & 3 & 2 & 1 & 1 & 0 & 0 & 2 & 2 & 32 & 3 & 92 & 2 \\
\hline Butter unsalted & Fatty & 7 & 3 & 2 & 1 & 1 & 0 & 0 & 1 & 1 & 4 & 2 & 95 & 1 \\
\hline Buttermilk & Sweet Sour & 12 & 6 & 1 & 37 & 1 & 1 & 1 & 2 & 1 & 5 & 3 & 24 & 3 \\
\hline Cabbage oxheart boiled & Neutral & 7 & 3 & 1 & 3 & 2 & 6 & 2 & 1 & 0 & 1 & 0 & 6 & 4 \\
\hline Cabbage red with apple pieces frozen boiled & Neutral & 9 & 24 & 3 & 10 & 2 & 4 & 2 & 10 & 3 & 15 & 4 & 12 & 3 \\
\hline Cabbage sauerkraut cooked & Sweet Sour & 7 & 6 & 4 & 70 & 2 & 4 & 2 & 2 & 1 & 17 & 7 & 4 & 2 \\
\hline
\end{tabular}




\begin{tabular}{|c|c|c|c|c|c|c|c|c|c|c|c|c|c|c|}
\hline \multirow[t]{2}{*}{ Food } & \multirow[t]{2}{*}{ Cluster } & \multirow[t]{2}{*}{$\mathrm{n}$} & \multicolumn{2}{|c|}{ Sweet } & \multicolumn{2}{|c|}{ Sour } & \multicolumn{2}{|c|}{ Bitter } & \multicolumn{2}{|c|}{ Umami } & \multicolumn{2}{|c|}{ Salt } & \multicolumn{2}{|c|}{ Fat } \\
\hline & & & $\mathrm{m}$ & SE & $\mathrm{m}$ & SE & $\mathrm{m}$ & SE & $\mathrm{m}$ & SE & $\mathrm{m}$ & SE & $\mathrm{m}$ & SE \\
\hline Cake butter Dutch Boterkoek & Sweet Fatty & 8 & 52 & 3 & 2 & 1 & 0 & 0 & 0 & 0 & 18 & 5 & 58 & 7 \\
\hline Cake chocolate made with butter & Sweet Fatty & 8 & 44 & 3 & 1 & 0 & 9 & 4 & 0 & 0 & 11 & 4 & 40 & 3 \\
\hline Cake chocolate made without butter & Sweet Fatty & 9 & 39 & 3 & 1 & 0 & 3 & 2 & 1 & 0 & 7 & 3 & 29 & 5 \\
\hline Cake Dutch spiced Ontbijtkoek & Sweet Fatty & 11 & 42 & 4 & 2 & 1 & 5 & 1 & 1 & 1 & 8 & 3 & 22 & 4 \\
\hline Cake Dutch spiced Ontbijtkoek with raisin & Sweet Fatty & 11 & 45 & 4 & 6 & 2 & 5 & 2 & 1 & 0 & 10 & 3 & 31 & 4 \\
\hline Cake Dutch spiced Ontbijtkoek wholemeal & Sweet Fatty & 7 & 41 & 6 & 1 & 1 & 2 & 1 & 1 & 1 & 9 & 4 & 17 & 5 \\
\hline Cake Dutchspiced Ontbijtkoek with rockcandy & Sweet Fatty & 8 & 52 & 6 & 1 & 1 & 3 & 1 & 3 & 2 & 11 & 4 & 21 & 4 \\
\hline Cake raisins- & Sweet Fatty & 8 & 46 & 2 & 1 & 1 & 0 & 0 & 0 & 0 & 11 & 4 & 44 & 5 \\
\hline Cake sponge Dutch Eierkoek & Sweet Fatty & 10 & 38 & 3 & 1 & 0 & 1 & 0 & 1 & 1 & 7 & 3 & 18 & 4 \\
\hline Cake wrapped in marzipan and chocolate & Sweet Fatty & 9 & 70 & 3 & 2 & 1 & 6 & 3 & 1 & 1 & 5 & 2 & 56 & 5 \\
\hline Candybar KitKat & Sweet Fatty & 8 & 59 & 4 & 1 & 1 & 3 & 1 & 0 & 0 & 12 & 4 & 47 & 4 \\
\hline Candybar Lion & Sweet Fatty & 7 & 59 & 4 & 1 & 1 & 2 & 1 & 0 & 0 & 13 & 5 & 42 & 3 \\
\hline Candybar Mars & Sweet Fatty & 12 & 64 & 4 & 3 & 1 & 4 & 1 & 1 & 0 & 10 & 4 & 57 & 5 \\
\hline Candybar Milky Way & Sweet Fatty & 11 & 67 & 3 & 3 & 1 & 4 & 1 & 0 & 0 & 10 & 3 & 65 & 4 \\
\hline Candybar Snickers & Sweet Fatty & 9 & 62 & 3 & 1 & 0 & 2 & 1 & 2 & 1 & 15 & 4 & 60 & 4 \\
\hline Candybar Twix & Sweet Fatty & 9 & 64 & 4 & 0 & 0 & 2 & 1 & 0 & 0 & 10 & 4 & 47 & 4 \\
\hline Carrots boiled average & Neutral & 10 & 15 & 2 & 2 & 1 & 1 & 1 & 3 & 2 & 2 & 1 & 10 & 3 \\
\hline Carrots raw average & Neutral & 10 & 15 & 2 & 4 & 2 & 2 & 1 & 2 & 1 & 2 & 1 & 4 & 2 \\
\hline Carrots tinned & Neutral & 7 & 15 & 1 & 2 & 1 & 2 & 1 & 3 & 1 & 10 & 3 & 11 & 3 \\
\hline Cashew nuts unsalted & Neutral & 7 & 10 & 2 & 1 & 1 & 1 & 0 & 11 & 4 & 14 & 4 & 39 & 8 \\
\hline Cassave crackers & Savory fatty & 9 & 15 & 3 & 1 & 1 & 1 & 0 & 19 & 3 & 31 & 4 & 29 & 5 \\
\hline Cauliflower boiled & Neutral & 10 & 6 & 1 & 4 & 2 & 3 & 1 & 4 & 2 & 3 & 1 & 11 & 4 \\
\hline Celeriac boiled & Neutral & 7 & 12 & 2 & 3 & 2 & 3 & 1 & 3 & 1 & 3 & 2 & 11 & 5 \\
\hline Cheese 20+ & Savory fatty & 8 & 5 & 2 & 14 & 5 & 1 & 1 & 21 & 7 & 39 & 6 & 55 & 5 \\
\hline Cheese 30+ & Savory fatty & 12 & 7 & 2 & 16 & 4 & 2 & 1 & 18 & 6 & 40 & 4 & 46 & 3 \\
\hline Cheese Brie 60+ & Savory fatty & 7 & 4 & 1 & 11 & 4 & 13 & 6 & 14 & 7 & 38 & 4 & 68 & 3 \\
\hline Cheese cream soft Boursin & Savory fatty & 8 & 8 & 3 & 32 & 5 & 2 & 2 & 12 & 5 & 40 & 7 & 69 & 1 \\
\hline Cheese cream soft Mon Chou & Fatty & 8 & 7 & 2 & 15 & 3 & 1 & 1 & 4 & 2 & 21 & 4 & 79 & 2 \\
\hline
\end{tabular}




\begin{tabular}{|c|c|c|c|c|c|c|c|c|c|c|c|c|c|c|}
\hline \multirow[t]{2}{*}{ Food } & \multirow[t]{2}{*}{ Cluster } & \multirow[t]{2}{*}{$\mathrm{n}$} & \multicolumn{2}{|c|}{ Sweet } & \multicolumn{2}{|c|}{ Sour } & \multicolumn{2}{|c|}{ Bitter } & \multicolumn{2}{|c|}{ Umami } & \multicolumn{2}{|c|}{ Salt } & \multicolumn{2}{|c|}{ Fat } \\
\hline & & & $\mathrm{m}$ & SE & $\mathrm{m}$ & SE & $\mathrm{m}$ & SE & $\mathrm{m}$ & SE & $\mathrm{m}$ & SE & $\mathrm{m}$ & $\mathrm{SE}$ \\
\hline Cheese cream soft Paturain & Savory fatty & 11 & 6 & 2 & 27 & 6 & 1 & 1 & 17 & 5 & 50 & 6 & 65 & 3 \\
\hline Cheese Edam 40+ & Savory fatty & 12 & 4 & 1 & 21 & 5 & 3 & 1 & 16 & 6 & 45 & 5 & 50 & 4 \\
\hline Cheese goat fresh & Savory fatty & 8 & 5 & 2 & 45 & 7 & 1 & 1 & 11 & 6 & 32 & 6 & 61 & 6 \\
\hline Cheese goat hard & Savory fatty & 8 & 9 & 3 & 22 & 6 & 2 & 1 & 24 & 10 & 37 & 7 & 62 & 5 \\
\hline Cheese Gouda 48+ average & Savory fatty & 12 & 6 & 2 & 18 & 5 & 1 & 0 & 17 & 6 & 41 & 4 & 51 & 4 \\
\hline Cheese Leerdammer/Maasdammer 45+ & Savory fatty & 12 & 6 & 1 & 10 & 3 & 2 & 1 & 28 & 7 & 29 & 4 & 50 & 5 \\
\hline Cheese Mozzarella & Neutral & 7 & 2 & 1 & 7 & 2 & 1 & 1 & 3 & 2 & 9 & 3 & 40 & 9 \\
\hline Cheese sheep fresh & Savory fatty & 7 & 4 & 2 & 10 & 5 & 1 & 1 & 44 & 10 & 38 & 5 & 53 & 6 \\
\hline Cheese spread 20+ & Savory fatty & 8 & 4 & 2 & 14 & 4 & 5 & 3 & 30 & 7 & 41 & 7 & 70 & 2 \\
\hline Cheese spread $48+$ & Savory fatty & 7 & 6 & 2 & 22 & 5 & 5 & 3 & 18 & 7 & 55 & 6 & 67 & 4 \\
\hline Chewing gum without sugar & Neutral & 12 & 29 & 3 & 2 & 1 & 2 & 1 & 0 & 0 & 1 & 1 & 4 & 2 \\
\hline Chicken cordon bleu (pan-fried) & Savory fatty & 7 & 5 & 3 & 7 & 4 & 1 & 1 & 28 & 8 & 46 & 5 & 60 & 6 \\
\hline Chicken fillet (pan-fried) & Neutral & 9 & 6 & 2 & 7 & 3 & 1 & 0 & 13 & 5 & 18 & 3 & 29 & 4 \\
\hline Chicken nuggets prepared in oven & Savoury fatty & 7 & 7 & 3 & 3 & 2 & 1 & 1 & 21 & 6 & 35 & 3 & 49 & 5 \\
\hline Chicken schnitzel (pan-fried) & Savory fatty & 7 & 6 & 2 & 2 & 1 & 1 & 1 & 13 & 3 & 35 & 3 & 42 & 6 \\
\hline Chicory boiled & Neutral & 9 & 5 & 1. & 1 & 0 & 11 & 2 & 1 & 0 & 2 & 1 & 7 & 2 \\
\hline Chines noodle ball (deep-fried) & Savory fatty & 7 & 3 & 3 & 3 & 2 & 1 & 1 & 37 & 9 & 45 & 4 & 54 & 6 \\
\hline Chips pre-fried (deep-fried) & Neutral & 9 & 9 & 3 & 3 & 2 & 0 & 0 & 7 & 2 & 15 & 2 & 42 & 6 \\
\hline Chocolate bar milk with nuts & Sweet Fatty & 10 & 65 & 3 & 2 & 1 & 3 & 1 & 5 & 3 & 11 & 3 & 64 & 3 \\
\hline Chocolate chip cookie & Sweet Fatty & 7 & 47 & 3 & 0 & 0 & 4 & 2 & 0 & 0 & 13 & 6 & 29 & 4 \\
\hline Chocolate confetti milk & Sweet Fatty & 8 & 60 & 4 & 1 & 1 & 3 & 1 & 0 & 0 & 6 & 3 & 34 & 7 \\
\hline Chocolate confetti mix white and plain & Sweet Fatty & 8 & 56 & 7 & 1 & 1 & 4 & 2 & 0 & 0 & 6 & 4 & 37 & 6 \\
\hline Chocolate confetti plain & Sweet Fatty & 8 & 54 & 6 & 1 & 1 & 6 & 2 & 0 & 0 & 6 & 3 & 35 & 5 \\
\hline Chocolate eclair & Sweet Fatty & 13 & 56 & 3 & 3 & 2 & 5 & 2 & 1 & 0 & 9 & 2 & 62 & 3 \\
\hline Chocolate flakes milk & Sweet Fatty & 8 & 60 & 5 & 1 & 1 & 6 & 3 & 0 & 0 & 3 & 2 & 34 & 6 \\
\hline Chocolate flakes plain & Sweet Fatty & 8 & 52 & 6 & 0 & 0 & 10 & 4 & 0 & 0 & 6 & 4 & 37 & 8 \\
\hline Chocolate milk & Sweet Fatty & 12 & 55 & 5 & 1 & 1 & 5 & 2 & 0 & 0 & 7 & 3 & 66 & 1 \\
\hline Chocolate plain & Sweet Fatty & 10 & 44 & 5 & 6 & 4 & 39 & 7 & 1 & 1 & 4 & 2 & 58 & 3 \\
\hline
\end{tabular}




\begin{tabular}{|c|c|c|c|c|c|c|c|c|c|c|c|c|c|c|}
\hline \multirow[t]{2}{*}{ Food } & \multirow[t]{2}{*}{ Cluster } & \multirow[t]{2}{*}{$\mathrm{n}$} & \multicolumn{2}{|c|}{ Sweet } & \multicolumn{2}{|l|}{ Sour } & \multicolumn{2}{|c|}{ Bitter } & \multicolumn{2}{|c|}{ Umami } & \multicolumn{2}{|c|}{ Salt } & \multicolumn{2}{|c|}{ Fat } \\
\hline & & & $\mathrm{m}$ & SE & $\mathrm{m}$ & SE & $\mathrm{m}$ & SE & $\mathrm{m}$ & SE & $\mathrm{m}$ & SE & $\mathrm{m}$ & $\mathrm{SE}$ \\
\hline Chocolate plain with nuts & Sweet Fatty & 8 & 38 & 4 & 1 & 1 & 31 & 6 & 2 & 2 & 8 & 3 & 57 & 4 \\
\hline Chocolate pudding with sauce & Sweet Fatty & 8 & 42 & 4 & 1 & 1 & 9 & 3 & 0 & 0 & 5 & 3 & 48 & 3 \\
\hline Chocolates filled/Belguim chocolate & Sweet Fatty & 11 & 64 & 3 & 1 & 1 & 7 & 2 & 0 & 0 & 6 & 3 & 66 & 2 \\
\hline Cocktail snacks based on corn or wheat & Savory fatty & 10 & 12 & 3 & 8 & 4 & 1 & 0 & 37 & 8 & 55 & 2 & 49 & 4 \\
\hline Cocktail snacks Nibbits & Savory fatty & 7 & 7 & 2 & 3 & 2 & 0 & 0 & 26 & 6 & 42 & 4 & 39 & 7 \\
\hline Cod boiled & Neutral & 8 & 2 & 1 & 3 & 1 & 2 & 1 & 12 & 4 & 13 & 2 & 20 & 4 \\
\hline Coffee cappuccino instant prepared & Bitter & 11 & 8 & 2 & 9 & 3 & 44 & 4 & 1 & 1 & 2 & 1 & 8 & 4 \\
\hline Coffee creamer full fat, with coffee & Bitter & 11 & 6 & 2 & 8 & 3 & 54 & 4 & 1 & 1 & 2 & 1 & 7 & 3 \\
\hline Coffee creamer half fat, with coffee & Bitter & 9 & 4 & 2 & 6 & 2 & 60 & 3 & 1 & 0 & 3 & 2 & 7 & 3 \\
\hline Coffee creamer powder, with coffee & Bitter & 11 & 3 & 1 & 5 & 2 & 59 & 4 & 0 & 0 & 2 & 2 & 7 & 3 \\
\hline Coffee prepared & Bitter & 11 & 2 & 1 & 9 & 3 & 63 & 2 & 1 & 0 & 3 & 2 & 4 & 2 \\
\hline Coffee with sugar and milk, vending machine & Bitter & 10 & 26 & 3 & 10 & 4 & 36 & 7 & 1 & 0 & 3 & 2 & 18 & 6 \\
\hline Colored confetti fruit-flavored & Sweet Fatty & 8 & 69 & 2 & 3 & 2 & 0 & 0 & 0 & 0 & 3 & 3 & 12 & 4 \\
\hline Cooking fat liquid $97 \%$ fat $<17 \mathrm{~g}$ salt unsalted & Fatty & 11 & 8 & 3 & 5 & 3 & 1 & 0 & 10 & 5 & 32 & 5 & 88 & 4 \\
\hline Cooking fat liquid $97 \%$ fat $<17 \mathrm{~g}$ salt & Fatty & 11 & 8 & 3 & 8 & 4 & 1 & 0 & 23 & 6 & 56 & 5 & 90 & 2 \\
\hline Cooking fat solid $97 \%$ fat $>17 \mathrm{~g}$ salt & Fatty & 11 & 5 & 2 & 3 & 1 & 1 & 0 & 16 & 6 & 19 & 4 & 92 & 3 \\
\hline Corned beef & Savory fatty & 7 & 4 & 2 & 8 & 3 & 1 & 0 & 23 & 8 & 43 & 4 & 44 & 9 \\
\hline Courgettes boiled & Neutral & 9 & 7 & 1 & 1 & 0 & 2 & 1 & 4 & 2 & 2 & 1 & 9 & 3 \\
\hline Crackers cream & Neutral & 9 & 5 & 2 & 1 & 0 & 1 & 0 & 1 & 0 & 8 & 1 & 7 & 1 \\
\hline Cream slice Dutch Tompouce & Sweet Fatty & 8 & 54 & 4 & 2 & 1 & 0 & 0 & 1 & 1 & 4 & 2 & 40 & 3 \\
\hline Cream whipped with added sugar & Sweet Fatty & 12 & 49 & 3 & 2 & 1 & 0 & 0 & 1 & 0 & 2 & 1 & 51 & 4 \\
\hline Creme fraiche & Fatty & 9 & 4 & 1 & 33 & 2 & 1 & 0 & 2 & 1 & 8 & 3 & 64 & 3 \\
\hline Crispbakes Dutch & Neutral & 12 & 12 & 2 & 2 & 1 & 1 & 0 & 1 & 0 & 9 & 2 & 4 & 1 \\
\hline Crispbakes Dutch wholemeal & Neutral & 12 & 11 & 1 & 2 & 1 & 1 & 0 & 1 & 0 & 10 & 2 & 4 & 1 \\
\hline Crispbread sesame & Neutral & 8 & 5 & 2 & 1 & 0 & 1 & 0 & 0 & 0 & 15 & 2 & 4 & 1 \\
\hline Crispbread wholemeal & Neutral & 11 & 5 & 1 & 4 & 1 & 4 & 1 & 1 & 1 & 11 & 2 & 2 & 1 \\
\hline Crisps maize Bugles & Savory fatty & 7 & 13 & 4 & 3 & 2 & 0 & 0 & 19 & 4 & 46 & 2 & 30 & 4 \\
\hline Crisps potato average & Savory fatty & 11 & 11 & 3 & 5 & 2 & 1 & 0 & 17 & 5 & 43 & 3 & 30 & 6 \\
\hline
\end{tabular}




\begin{tabular}{|c|c|c|c|c|c|c|c|c|c|c|c|c|c|c|}
\hline \multirow[t]{2}{*}{ Food } & \multirow[t]{2}{*}{ Cluster } & \multirow[t]{2}{*}{$\mathrm{n}$} & \multicolumn{2}{|c|}{ Sweet } & \multicolumn{2}{|c|}{ Sour } & \multicolumn{2}{|c|}{ Bitter } & \multicolumn{2}{|c|}{ Umami } & \multicolumn{2}{|c|}{ Salt } & \multicolumn{2}{|c|}{ Fat } \\
\hline & & & $\mathrm{m}$ & SE & $\mathrm{m}$ & SE & $\mathrm{m}$ & SE & $\mathrm{m}$ & SE & $\mathrm{m}$ & SE & $\mathrm{m}$ & $\mathrm{SE}$ \\
\hline Crisps potato flavored & Savory fatty & 8 & 11 & 3 & 7 & 3 & 1 & 0 & 26 & 6 & 47 & 6 & 40 & 6 \\
\hline Crisps potato Lays Sensations flavored & Savory fatty & 9 & 12 & 2 & 4 & 2 & 0 & 0 & 14 & 3 & 54 & 3 & 38 & 8 \\
\hline Crisps potato light flavored & Savory fatty & 7 & 12 & 4 & 7 & 3 & 0 & 0 & 17 & 4 & 47 & 5 & 44 & 9 \\
\hline Crisps potato light unflavored & Savory fatty & 9 & 8 & 2 & 2 & 1 & 0 & 0 & 6 & 2 & 57 & 1 & 40 & 7 \\
\hline Crisps potato unflavored & Savory fatty & 12 & 4 & 1 & 4 & 2 & 1 & 1 & 8 & 2 & 48 & 2 & 25 & 5 \\
\hline Crisps tortilla unflavored & Neutral & 9 & 5 & 2 & 1 & 1 & 1 & 0 & 4 & 2 & 29 & 4 & 21 & 6 \\
\hline Croissant average & Neutral & 8 & 13 & 3 & 2 & 1 & 1 & 1 & 1 & 0 & 19 & 2 & 35 & 6 \\
\hline Croissant with ham and cheese & Savory fatty & 8 & 10 & 3 & 4 & 2 & 1 & 1 & 16 & 7 & 38 & 6 & 43 & 7 \\
\hline Croquette meat ragout frozen (deep-fried) & Savory fatty & 9 & 9 & 3 & 6 & 2 & 1 & 0 & 25 & 7 & 44 & 5 & 63 & 5 \\
\hline Cucumber with skin raw & Neutral & 11 & 6 & 1 & 4 & 1 & 4 & 1 & 1 & 1 & 1 & 0 & 3 & 1 \\
\hline Cucumber without skin raw & Neutral & 11 & 7 & 1 & 2 & 1 & 2 & 1 & 1 & 0 & 1 & 0 & 2 & 1 \\
\hline Cupcake iced & Sweet Fatty & 10 & 70 & 2 & 2 & 1 & 1 & 0 & 0 & 0 & 8 & 3 & 38 & 5 \\
\hline Custard chocolate full fat & Sweet Fatty & 9 & 34 & 1 & 1 & 1 & 6 & 2 & 1 & 1 & 4 & 2 & 40 & 2 \\
\hline Custard several flavors full fat & Sweet Fatty & 12 & 36 & 3 & 3 & 1 & 8 & 2 & 1 & 0 & 4 & 2 & 42 & 3 \\
\hline Custard soft \& airy Campina & Sweet Fatty & 8 & 42 & 3 & 0 & 0 & 0 & 0 & 1 & 1 & 4 & 2 & 49 & 3 \\
\hline Custard vanilla full fat & Sweet Fatty & 12 & 33 & 1. & 3 & 1 & 1 & 0 & 1 & 0 & 2 & 1 & 39 & 3 \\
\hline Dairy dr Milk\&Fruit strawberry-cherry & Sweet Sour & 8 & 31 & 3 & 26 & 3 & 2 & 2 & 1 & 1 & 5 & 2 & 20 & 4 \\
\hline Dairy drink Campina fruitmilk & Sweet Fatty & 8 & 35 & 1 & 1 & 1 & 0 & 0 & 2 & 2 & 4 & 2 & 18 & 2 \\
\hline Dairy spread plain/herbs & Fatty & 12 & 9 & 3 & 20 & 5 & 1 & 0 & 19 & 6 & 30 & 4 & 71 & 1 \\
\hline Dates fresh & Sweet Fatty & 8 & 46 & 4 & 3 & 3 & 0 & 0 & 1 & 1 & 2 & 1 & 19 & 2 \\
\hline Doughnuts plain & Sweet Fatty & 8 & 44 & 4 & 1 & 1 & 1 & 0 & 1 & 1 & 12 & 4 & 49 & 4 \\
\hline Duck whole fried in non-stick coating pan & Savory fatty & 7 & 4 & 2 & 7 & 2 & 2 & 1 & 27 & 9 & 16 & 3 & 37 & 8 \\
\hline Eclair with whipped cream filling & Sweet Fatty & 8 & 44 & 2 & 1 & 1 & 0 & 0 & 1 & 1 & 8 & 3 & 47 & 5 \\
\hline Eggs chicken boiled average & Neutral & 12 & 5 & 1 & 2 & 1 & 1 & 0 & 8 & 3 & 10 & 1 & 26 & 5 \\
\hline Endive boiled & Neutral & 9 & 3 & 1 & 1 & 0 & 8 & 2 & 2 & 2 & 1 & 1 & 6 & 2 \\
\hline Endive raw & Neutral & 9 & 4 & 1 & 1 & 0 & 10 & 2 & 1 & 0 & 1 & 1 & 2 & 1 \\
\hline Energy drink Golden Power/Bullit & Sweet Sour & 8 & 42 & 7 & 33 & 5 & 5 & 2 & 0 & 0 & 2 & 1 & 1 & 1 \\
\hline Energy drink Red Bull/Euroshopper/Rodeo & Sweet Sour & 9 & 55 & 5 & 39 & 6 & 10 & 4 & 0 & 0 & 3 & 2 & 4 & 1 \\
\hline
\end{tabular}




\begin{tabular}{|c|c|c|c|c|c|c|c|c|c|c|c|c|c|c|}
\hline \multirow[t]{2}{*}{ Food } & \multirow[t]{2}{*}{ Cluster } & \multirow[t]{2}{*}{$\mathrm{n}$} & \multicolumn{2}{|c|}{ Sweet } & \multicolumn{2}{|l|}{ Sour } & \multicolumn{2}{|c|}{ Bitter } & \multicolumn{2}{|c|}{ Umami } & \multicolumn{2}{|c|}{ Salt } & \multicolumn{2}{|c|}{ Fat } \\
\hline & & & $\mathrm{m}$ & $\mathrm{SE}$ & $\mathrm{m}$ & SE & $\mathrm{m}$ & SE & $\mathrm{m}$ & SE & $\mathrm{m}$ & SE & $\mathrm{m}$ & $\mathrm{SE}$ \\
\hline Fish fingers fried & Savory fatty & 8 & 6 & 2 & 4 & 2 & 1 & 0 & 23 & 5 & 41 & 4 & 51 & 5 \\
\hline Flan apple and crumble topping & Sweet Fatty & 11 & 49 & 3 & 15 & 5 & 1 & 1 & 0 & 0 & 11 & 3 & 42 & 4 \\
\hline Flan filled with rice pudding & Sweet Fatty & 7 & 35 & 4 & 1 & 1 & 0 & 0 & 2 & 1 & 13 & 5 & 44 & 2 \\
\hline Flan with fruit filling & Sweet Fatty & 7 & 46 & 7 & 32 & 5 & 1 & 1 & 0 & 0 & 11 & 5 & 35 & 4 \\
\hline Fromage frais half fat with fruit & Sweet Fatty & 9 & 48 & 4 & 22 & 2 & 1 & 0 & 1 & 1 & 3 & 2 & 45 & 3 \\
\hline Fromage frais low fat & Sweet Sour & 7 & 2 & 1 & 51 & 2 & 1 & 0 & 1 & 1 & 0 & 0 & 35 & 3 \\
\hline Fromage frais low fat with fruit & Sweet Sour & 7 & 29 & 2 & 29 & 3 & 1 & 0 & 0 & 0 & 3 & 2 & 37 & 1 \\
\hline Fruit cocktail in syrup tinned & Sweet Sour & 9 & 37 & 4 & 10 & 2 & 0 & 0 & 1 & 0 & 2 & 2 & 9 & 3 \\
\hline Fruit drink concentrate can Albert Heijn & Neutral & 8 & 37 & 2 & 5 & 2 & 1 & 1 & 0 & 0 & 2 & 1 & 1 & 1 \\
\hline Fruit drink concentrate fruitmix & Sweet Sour & 8 & 65 & 10 & 18 & 5 & 0 & 0 & 0 & 0 & 0 & 0 & 5 & 2 \\
\hline Fruit drink concentrate Karvan Cevitam & Sweet Sour & 7 & 42 & 2 & 8 & 4 & 1 & 0 & 0 & 0 & 2 & 2 & 2 & 1 \\
\hline Fruit drink concentrate undiluted & Sweet Fatty & 12 & 70 & 4 & 15 & 5 & 1 & 0 & 0 & 0 & 2 & 2 & 5 & 2 \\
\hline Fruit juice concentrated & Sweet Sour & 8 & 62 & 11 & 46 & 8 & 0 & 0 & 0 & 0 & 0 & 0 & 6 & 3 \\
\hline Fruit juice dk minimal 2 fruits & Sweet Sour & 9 & 51 & 3 & 34 & 3 & 3 & 2 & 0 & 0 & 3 & 2 & 7 & 3 \\
\hline Fruit juice dk minimal 2 fruits with vitamin $C$ & Sweet Sour & 9 & 43 & 4 & 26 & 2 & 1 & 0 & 0 & 0 & 2 & 2 & 4 & 1 \\
\hline Fruit juice drink Roosvicee Multivitamin & Sweet Sour & 9 & 39 & 4 & 35 & 3 & 1 & 0 & 0 & 0 & 2 & 2 & 1 & 1 \\
\hline Gateau fatless sponge with fruit $\&$ cream & Sweet Fatty & 12 & 46 & 3 & 13 & 3 & 1 & 1 & 0 & 0 & 7 & 2 & 45 & 4 \\
\hline Gateau with whipped cream & Sweet Fatty & 10 & 48 & 3 & 3 & 1 & 0 & 0 & 1 & 1 & 7 & 3 & 51 & 5 \\
\hline Gherkins sweet pickled & Sweet Sour & 12 & 12 & 3 & 69 & 1 & 1 & 0 & 2 & 1 & 9 & 4 & 7 & 2 \\
\hline Grapes with skin average & Sweet Sour & 12 & 30 & 3 & 25 & 3 & 2 & 1 & 0 & 0 & 1 & 0 & 5 & 2 \\
\hline Ham lean boiled & Savory fatty & 12 & 5 & 1 & 5 & 2 & 0 & 0 & 31 & 6 & 46 & 3 & 41 & 5 \\
\hline Ham lean grilled & Savory fatty & 7 & 4 & 2 & 9 & 3 & 1 & 0 & 26 & 8 & 43 & 5 & 40 & 7 \\
\hline Ham shoulder medium fat boiled & Savory fatty & 12 & 8 & 2 & 6 & 3 & 1 & 1 & 23 & 5 & 45 & 3 & 39 & 5 \\
\hline Ham smoked raw & Savory fatty & 8 & 3 & 2 & 4 & 1 & 1 & 1 & 27 & 6 & 65 & 5 & 57 & 5 \\
\hline Hamburger (pan-fried) & Savory fatty & 9 & 9 & 2 & 5 & 2 & 1 & 0 & 31 & 7 & 46 & 5 & 54 & 4 \\
\hline Herring pickled (sweet)sour & Savory fatty & 11 & 4 & 1 & 73 & 3 & 3 & 1 & 18 & 5 & 36 & 6 & 39 & 3 \\
\hline Herring salted & Savory fatty & 8 & 3 & 1 & 11 & 4 & 2 & 1 & 40 & 7 & 50 & 4 & 58 & 4 \\
\hline Honey & Sweet Fatty & 8 & 76 & 3 & 1 & 1 & 3 & 2 & 0 & 0 & 4 & 2 & 29 & 8 \\
\hline
\end{tabular}




\begin{tabular}{|c|c|c|c|c|c|c|c|c|c|c|c|c|c|c|}
\hline \multirow[t]{2}{*}{ Food } & \multirow[t]{2}{*}{ Cluster } & \multirow[t]{2}{*}{$\mathrm{n}$} & \multicolumn{2}{|c|}{ Sweet } & \multicolumn{2}{|l|}{ Sour } & \multicolumn{2}{|c|}{ Bitter } & \multicolumn{2}{|c|}{ Umami } & \multicolumn{2}{|c|}{ Salt } & \multicolumn{2}{|c|}{ Fat } \\
\hline & & & $\mathrm{m}$ & SE & $\mathrm{m}$ & $\mathrm{SE}$ & $\mathrm{m}$ & SE & $\mathrm{m}$ & SE & $\mathrm{m}$ & SE & $\mathrm{m}$ & SE \\
\hline Hot chocolate from vending machine & Sweet Fatty & 11 & 48 & 3 & 2 & 1 & 8 & 3 & 0 & 0 & 5 & 3 & 14 & 3 \\
\hline Ice cream dairy cornet & Sweet Fatty & 12 & 47 & 3 & 4 & 3 & 4 & 2 & 1 & 1 & 7 & 2 & 50 & 4 \\
\hline Ice cream dairy cream based & Sweet Fatty & 8 & 48 & 4 & 2 & 1 & 0 & 0 & 0 & 0 & 5 & 3 & 52 & 2 \\
\hline Ice cream dairy with chocolate coating & Sweet Fatty & 7 & 40 & 2 & 1 & 0 & 3 & 2 & 1 & 1 & 4 & 2 & 55 & 6 \\
\hline Ice cream stracciatella- & Sweet Fatty & 7 & 47 & 4 & 1 & 0 & 4 & 2 & 1 & 1 & 7 & 3 & 47 & 3 \\
\hline Jam & Sweet Fatty & 8 & 74 & 3 & 19 & 3 & 1 & 0 & 0 & 0 & 3 & 2 & 27 & 7 \\
\hline Jam reduced sugar & Sweet Fatty & 8 & 58 & 5 & 19 & 4 & 1 & 1 & 0 & 0 & 4 & 2 & 26 & 7 \\
\hline Japanese rice cracker mix with peanuts & Neutral & 7 & 16 & 2 & 1 & 1 & 1 & 1 & 16 & 6 & 26 & 5 & 18 & 2 \\
\hline Japanese rice cracker mix without peanuts & Neutral & 8 & 9 & 2 & 2 & 1 & 1 & 1 & 10 & 3 & 28 & 5 & 9 & 1 \\
\hline Juice apple, Appelsientje, Goudappel & Sweet Sour & 11 & 35 & 6 & 44 & 6 & 2 & 1 & 0 & 0 & 1 & 1 & 1 & 1 \\
\hline Juice drink & Sweet Sour & 12 & 50 & 4 & 33 & 2 & 7 & 3 & 0 & 0 & 2 & 2 & 4 & 2 \\
\hline Juice drink Dubbelfrisss & Sweet Sour & 11 & 37 & 4 & 23 & 4 & 1 & 1 & 0 & 0 & 2 & 2 & 4 & 2 \\
\hline Juice drink Spa\&Fruit still & Sweet Sour & 8 & 36 & 5 & 19 & 3 & 0 & 0 & 0 & 0 & 3 & 2 & 2 & 1 \\
\hline Juice drink Vruchtenfris/Tintelfruit & Sweet Sour & 7 & 37 & 4 & 35 & 5 & 1 & 1 & 0 & 0 & 2 & 1 & 1 & 1 \\
\hline Juice drink Wicky & Sweet Sour & 8 & 43 & 6 & 32 & 4 & 1 & 0 & 0 & 0 & 4 & 3 & 2 & 1 \\
\hline Juice drink with sugar \& sweetener & Sweet Sour & 7 & 53 & 4 & 24 & 4 & 3 & 2 & 0 & 0 & 2 & 1 & 4 & 1 \\
\hline Juice mixed fruit, AH BASIC Multivitaminedrank & Sweet Sour & 11 & 40 & 5 & 30 & 6 & 3 & 1 & 0 & 0 & 1 & 1 & 2 & 1 \\
\hline Juice orange freshly squeezed & Sweet Sour & 12 & 31 & 4 & 61 & 3 & 11 & 5 & 0 & 0 & 2 & 1 & 6 & 2 \\
\hline Juice orange with pulp & Sweet Sour & 8 & 21 & 4 & 50 & 4 & 5 & 1 & 0 & 0 & 2 & 1 & 4 & 2 \\
\hline Juice orange, Appelsientje, Sinaasappel & Sweet Sour & 11 & 32 & 3 & 42 & 6 & 2 & 1 & 0 & 0 & 1 & 1 & 2 & 1 \\
\hline Kale curly boiled & Neutral & 7 & 3 & 1 & 1 & 0 & 7 & 2 & 2 & 2 & 2 & 1 & 4 & 3 \\
\hline Ketchup curry & Savory fatty & 9 & 31 & 3 & 22 & 6 & 1 & 0 & 22 & 6 & 33 & 6 & 32 & 5 \\
\hline Ketchup tomato & Sweet Sour & 9 & 28 & 3 & 42 & 6 & 1 & 1 & 22 & 6 & 29 & 6 & 27 & 5 \\
\hline Kiwi fruit & Sweet Sour & 12 & 19 & 3 & 51 & 4 & 4 & 1 & 0 & 0 & 1 & 0 & 7 & 2 \\
\hline Kromesky meat filled (pan-fried) & Savory fatty & 9 & 7 & 2 & 4 & 1 & 1 & 0 & 19 & 5 & 48 & 5 & 60 & 6 \\
\hline Leek boiled & Neutral & 8 & 6 & 2 & 3 & 1 & 5 & 1 & 3 & 1 & 2 & 1 & 9 & 3 \\
\hline Lemonade squash Dubbelfrisss light & Sweet Sour & 8 & 33 & 3 & 31 & 3 & 1 & 0 & 0 & 0 & 1 & 1 & 1 & 1 \\
\hline Lettuce head raw & Neutral & 8 & 5 & 2 & 3 & 1 & 9 & 2 & 1 & 1 & 1 & 0 & 2 & 1 \\
\hline
\end{tabular}




\begin{tabular}{|c|c|c|c|c|c|c|c|c|c|c|c|c|c|c|}
\hline \multirow[t]{2}{*}{ Food } & \multirow[t]{2}{*}{ Cluster } & \multirow[t]{2}{*}{$\mathrm{n}$} & \multicolumn{2}{|c|}{ Sweet } & \multicolumn{2}{|c|}{ Sour } & \multicolumn{2}{|c|}{ Bitter } & \multicolumn{2}{|c|}{ Umami } & \multicolumn{2}{|c|}{ Salt } & \multicolumn{2}{|c|}{ Fat } \\
\hline & & & $\mathrm{m}$ & $\mathrm{SE}$ & $\mathrm{m}$ & SE & $\mathrm{m}$ & SE & $\mathrm{m}$ & SE & $\mathrm{m}$ & SE & $\mathrm{m}$ & $\mathrm{SE}$ \\
\hline Lettuce iceberg raw & Neutral & 8 & 9 & 2 & 2 & 1 & 3 & 1 & 1 & 1 & 1 & 0 & 4 & 2 \\
\hline Lipton Ice Tea Lemon & Sweet Sour & 12 & 39 & 3 & 29 & 3 & 4 & 2 & 2 & 1 & 3 & 2 & 5 & 3 \\
\hline Liquorice allsorts & Sweet Fatty & 9 & 65 & 3 & 1 & 1 & 1 & 1 & 0 & 0 & 10 & 4 & 24 & 3 \\
\hline Liquorice Dutch type salted & Sweet Fatty & 8 & 40 & 3 & 6 & 4 & 1 & 1 & 6 & 6 & 42 & 6 & 28 & 5 \\
\hline Liquorice Dutch type sweet & Sweet Fatty & 12 & 33 & 3 & 2 & 1 & 4 & 2 & 1 & 1 & 19 & 4 & 22 & 4 \\
\hline Liver pate & Savory fatty & 7 & 8 & 3 & 8 & 4 & 1 & 1 & 20 & 8 & 46 & 5 & 65 & 4 \\
\hline Liver pate sausage & Savory fatty & 9 & 5 & 2 & 6 & 2 & 4 & 3 & 19 & 7 & 40 & 5 & 63 & 6 \\
\hline Liver pate/Berliner liver sausage & Savory fatty & 11 & 7 & 2 & 11 & 3 & 2 & 1 & 27 & 5 & 31 & 5 & 59 & 3 \\
\hline Liver sausage & Savory fatty & 8 & 7 & 2 & 3 & 2 & 2 & 1 & 32 & 6 & 41 & 3 & 63 & 4 \\
\hline Low fat margarine $40 \%$ fat $<17$ g salt & Fatty & 8 & 3 & 1 & 1 & 1 & 0 & 0 & 2 & 2 & 12 & 2 & 89 & 3 \\
\hline Low fat margarine prod $35 \%$ fat $<10 \mathrm{~g}$ salt & Fatty & 9 & 2 & 1 & 1 & 1 & 1 & 0 & 1 & 1 & 2 & 1 & 84 & 6 \\
\hline Low fat margarine prod Blue Band Idee & Fatty & 8 & 3 & 1 & 2 & 1 & 0 & 0 & 1 & 1 & 13 & 2 & 83 & 4 \\
\hline Low fat margarine product tub Becel Ligh & Fatty & 8 & 1 & 1 & 1 & 1 & 0 & 0 & 1 & 1 & 3 & 1 & 78 & 7 \\
\hline Luncheon meat tinned & Savory fatty & 12 & 8 & 3 & 8 & 2 & 1 & 0 & 24 & 5 & 37 & 3 & 49 & 5 \\
\hline M\&M's chocolate with peanuts & Sweet Fatty & 12 & 57 & 3 & 2 & 1 & 3 & 1 & 2 & 1 & 7 & 2 & 28 & 4 \\
\hline Macaroons & Sweet Fatty & 8 & 58 & 4 & 1 & 0 & 1 & 1 & 1 & 0 & 9 & 4 & 28 & 4 \\
\hline Mackerel fillet smoked & Savory fatty & 8 & 3 & 1 & 8 & 4 & 1 & 0 & 44 & 8 & 42 & 5 & 52 & 8 \\
\hline Mandarins & Sweet Sour & 12 & 26 & 2 & 31 & 4 & 3 & 1 & 1 & 0 & 1 & 0 & 4 & 2 \\
\hline Margarine $80 \%$ fat $>24 \mathrm{~g}$ saturates & Fatty & 8 & 2 & 1 & 1 & 1 & 1 & 0 & 0 & 0 & 14 & 3 & 94 & 3 \\
\hline Margarine $80 \%$ fat $17-24 \mathrm{~g}$ saturates & Fatty & 12 & 4 & 1 & 4 & 2 & 0 & 0 & 2 & 1 & 10 & 2 & 84 & 3 \\
\hline Margarine liquid $80 \%$ fat $<17 \mathrm{~g}$ sat unsalted & Fatty & 0 & 3 & 2 & 1 & 1 & 1 & 1 & 1 & 1 & 9 & 3 & 87 & 3 \\
\hline Margarine liquid $80 \%$ fat $<17 \mathrm{~g}$ saturates & Fatty & 11 & 3 & 2 & 2 & 1 & 1 & 1 & 2 & 1 & 13 & 2 & 88 & 4 \\
\hline Margarine product $60 \%$ fat $<17$ g sat & Fatty & 12 & 2 & 1 & 5 & 3 & 1 & 1 & 2 & 1 & 4 & 1 & 78 & 6 \\
\hline Margarine product $70 \%$ fat $>17 \mathrm{~g}$ sat & Fatty & 11 & 2 & 1 & 2 & 1 & 1 & 0 & 2 & 1 & 14 & 2 & 84 & 5 \\
\hline Margarine product AlbertHeijn Bewust & Fatty & 11 & 5 & 2 & 5 & 2 & 1 & 0 & 2 & 1 & 7 & 2 & 91 & 3 \\
\hline Margarine product tub Becel Dieet & Fatty & 8 & 1 & 1 & 1 & 1 & 1 & 0 & 1 & 1 & 3 & 1 & 83 & 5 \\
\hline Marmite & Savory fatty & 12 & 11 & 4 & 23 & 7 & 23 & 7 & 64 & 9 & 62 & 7 & 19 & 5 \\
\hline Marsh mellows & Sweet Fatty & 8 & 65 & 1 & 2 & 2 & 0 & 0 & 0 & 0 & 2 & 2 & 33 & 7 \\
\hline
\end{tabular}




\begin{tabular}{|c|c|c|c|c|c|c|c|c|c|c|c|c|c|c|}
\hline \multirow[t]{2}{*}{ Food } & \multirow[t]{2}{*}{ Cluster } & \multirow[t]{2}{*}{$\mathrm{n}$} & \multicolumn{2}{|c|}{ Sweet } & \multicolumn{2}{|c|}{ Sour } & \multicolumn{2}{|c|}{ Bitter } & \multicolumn{2}{|c|}{ Umami } & \multicolumn{2}{|c|}{ Salt } & \multicolumn{2}{|c|}{ Fat } \\
\hline & & & $\mathrm{m}$ & $\mathrm{SE}$ & $\mathrm{m}$ & SE & $\mathrm{m}$ & SE & $\mathrm{m}$ & SE & $\mathrm{m}$ & SE & $\mathrm{m}$ & $\mathrm{SE}$ \\
\hline Mayonnaise & Fatty & 9 & 10 & 2 & 33 & 4 & 1 & 0 & 8 & 4 & 25 & 6 & 76 & 4 \\
\hline Mayonnaise product approx $35 \%$ oil & Fatty & 12 & 12 & 3 & 41 & 5 & 1 & 0 & 14 & 5 & 30 & 6 & 76 & 3 \\
\hline Mayonnaise yoghurt based $25 \%$ oil & Fatty & 8 & 15 & 4 & 32 & 4 & 1 & 0 & 7 & 5 & 24 & 6 & 69 & 5 \\
\hline Meringue cake Bokkenpootje & Sweet Fatty & 8 & 57 & 4 & 1 & 0 & 5 & 2 & 0 & 0 & 8 & 3 & 40 & 6 \\
\hline Milk chocolate-flavored Chocomel light & Sweet Fatty & 9 & 40 & 3 & 1 & 1 & 8 & 3 & 1 & 1 & 6 & 3 & 35 & 2 \\
\hline Milk chocolate-flavored full fat & Sweet Fatty & 9 & 37 & 4 & 2 & 2 & 7 & 3 & 0 & 0 & 6 & 3 & 39 & 2 \\
\hline Milk chocolate-flavored semi-skimmed & Sweet Fatty & 9 & 42 & 3 & 4 & 2 & 7 & 2 & 1 & 1 & 5 & 2 & 35 & 3 \\
\hline Milk semi-skimmed & Neutral & 12 & 12 & 1 & 4 & 1 & 1 & 0 & 1 & 0 & 3 & 1 & 20 & 3 \\
\hline Milk skimmed & Neutral & 12 & 14 & 2 & 5 & 1 & 1 & 0 & 1 & 0 & 2 & 1 & 18 & 3 \\
\hline Milk whole & Neutral & 12 & 12 & 1 & 4 & 1 & 1 & 0 & 1 & 0 & 3 & 1 & 20 & 3 \\
\hline Minced beef (pan-fried) & Savory fatty & 9 & 4 & 2 & 3 & 1 & 1 & 0 & 11 & 4 & 22 & 3 & 49 & 7 \\
\hline Minced beef/pork (pan-fried) & Savory fatty & 9 & 4 & 2 & 2 & 1 & 1 & 0 & 12 & 4 & 24 & 3 & 45 & 6 \\
\hline Minced meat beef/pork raw with egg/bread crumbs & Savory fatty & 10 & 9 & 3 & 7 & 2 & 1 & 0 & 24 & 5 & 43 & 4 & 57 & 4 \\
\hline Minced meat loaf fried & Savory fatty & 9 & 4 & 1 & 6 & 2 & 1 & 0 & 21 & 5 & 38 & 3 & 50 & 6 \\
\hline Minced meat with ham and cheese (pan-fried) & Savory fatty & 7 & 4 & 2 & 6 & 2 & 1 & 1 & 29 & 9 & 41 & 4 & 55 & 6 \\
\hline Mineral water average & Neutral & 12 & 2 & 1 & 17 & 4 & 19 & 6 & 0 & 0 & 2 & 1 & 3 & 2 \\
\hline Mineral water Spa (non-sparkling) & Neutral & 11 & 1 & 0 & 1 & 0 & 4 & 1 & 1 & 1 & 1 & 0 & 4 & 3 \\
\hline Mixed nuts and raisins & Neutral & 11 & 24 & 5 & 8 & 2 & 4 & 1 & 4 & 2 & 5 & 1 & 24 & 3 \\
\hline Mousse chocolate & Sweet Fatty & 8 & 46 & 6 & 1 & 1 & 14 & 5 & 1 & 1 & 3 & 1 & 49 & 3 \\
\hline Muesli crunchy plain/with fruit & Neutral & 8 & 35 & 5 & 8 & 2 & 1 & 0 & 1 & 0 & 10 & 3 & 10 & 2 \\
\hline Muesli crunchy with chocolate & Sweet Fatty & 7 & 45 & 3 & 0 & 0 & 3 & 2 & 0 & 0 & 12 & 5 & 17 & 3 \\
\hline Muesli crunchy with nuts & Neutral & 8 & 34 & 4 & 1 & 1 & 1 & 1 & 0 & 0 & 14 & 4 & 11 & 3 \\
\hline Muesli with fruit & Neutral & 8 & 11 & 2 & 4 & 2 & 2 & 1 & 1 & 0 & 4 & 2 & 5 & 2 \\
\hline Mushrooms boiled & Neutral & 8 & 7 & 2 & 3 & 1 & 2 & 1 & 18 & 3 & 5 & 2 & 18 & 6 \\
\hline Mustard & Savory fatty & 7 & 6 & 3 & 47 & 10 & 10 & 6 & 5 & 3 & 37 & 9 & 31 & 4 \\
\hline Nuts mixed salted & Savory fatty & 8 & 12 & 4 & 1 & 0 & 4 & 1 & 11 & 4 & 32 & 4 & 41 & 9 \\
\hline Oil olive & Fatty & 8 & 1 & 1 & 0 & 0 & 17 & 10 & 1 & 1 & 3 & 2 & 98 & 2 \\
\hline Oil soya & Fatty & 7 & 3 & 1 & 3 & 3 & 3 & 2 & 6 & 5 & 5 & 2 & 90 & 1 \\
\hline Oil sunflower seed & Fatty & 11 & 2 & 1 & 1 & 0 & 1 & 1 & 1 & 1 & 4 & 1 & 91 & 5 \\
\hline
\end{tabular}




\begin{tabular}{|c|c|c|c|c|c|c|c|c|c|c|c|c|c|c|}
\hline \multirow[t]{2}{*}{ Food } & \multirow[t]{2}{*}{ Cluster } & \multirow[t]{2}{*}{$\mathrm{n}$} & \multicolumn{2}{|c|}{ Sweet } & \multicolumn{2}{|l|}{ Sour } & \multicolumn{2}{|c|}{ Bitter } & \multicolumn{2}{|c|}{ Umami } & \multicolumn{2}{|c|}{ Salt } & \multicolumn{2}{|c|}{ Fat } \\
\hline & & & $\mathrm{m}$ & SE & $\mathrm{m}$ & SE & $\mathrm{m}$ & SE & $\mathrm{m}$ & SE & $\mathrm{m}$ & SE & $\mathrm{m}$ & SE \\
\hline Oil wok average & Fatty & 8 & 4 & 2 & 1 & 0 & 1 & 1 & 12 & 4 & 9 & 3 & 91 & 2 \\
\hline Olives tinned/glass & Neutral & 9 & 4 & 1 & 6 & 2 & 4 & 2 & 18 & 5 & 31 & 5 & 19 & 6 \\
\hline Onions boiled & Neutral & 8 & 7 & 2 & 4 & 1 & 3 & 0 & 5 & 1 & 2 & 1 & 12 & 5 \\
\hline Onions raw & Bitter & 9 & 9 & 2 & 8 & 3 & 31 & 9 & 3 & 1 & 3 & 1 & 3 & 2 \\
\hline Orange & Sweet Sour & 12 & 19 & 3 & 47 & 5 & 8 & 3 & 0 & 0 & 1 & 1 & 3 & 1 \\
\hline Pancake & Neutral & 10 & 15 & 2 & 2 & 1 & 1 & 0 & 2 & 2 & 8 & 2 & 35 & 5 \\
\hline Pasta plain average boiled & Neutral & 10 & 3 & 1 & 2 & 1 & 1 & 1 & 1 & 0 & 3 & 1 & 16 & 5 \\
\hline Pasta wholemeal boiled & Neutral & 10 & 4 & 2 & 2 & 1 & 2 & 1 & 1 & 0 & 6 & 2 & 13 & 2 \\
\hline Pastry puff cheese filled (deep-fried) & Savory fatty & 10 & 6 & 2 & 10 & 3 & 1 & 0 & 23 & 7 & 54 & 5 & 62 & 4 \\
\hline Pate & Savory fatty & 8 & 15 & 4 & 6 & 2 & 2 & 2 & 26 & 7 & 46 & 5 & 66 & 4 \\
\hline Pea garden super fine tinned & Neutral & 9 & 15 & 2 & 2 & 1 & 1 & 0 & 6 & 1 & 11 & 3 & 9 & 3 \\
\hline Peaches in syrup tinned & Sweet Sour & 9 & 31 & 4 & 14 & 2 & 2 & 1 & 1 & 0 & 2 & 2 & 9 & 4 \\
\hline Peanut butter & Fatty & 8 & 27 & 6 & 2 & 1 & 2 & 1 & 2 & 1 & 24 & 3 & 69 & 5 \\
\hline Peanut butter with nut pieces & Savory fatty & 7 & 24 & 3 & 4 & 2 & 2 & 1 & 8 & 3 & 33 & 7 & 65 & 8 \\
\hline Peanut sauce jar prepared & Savory fatty & 9 & 32 & 4 & 9 & 3 & 2 & 1 & 14 & 5 & 41 & 6 & 60 & 4 \\
\hline Peanuts coated & Savory fatty & 8 & 11 & 3 & 3 & 2 & 2 & 1 & 24 & 7 & 43 & 5 & 43 & 7 \\
\hline Peanuts salted & Savory fatty & 8 & 8 & 3 & 1 & 0 & 2 & 1 & 7 & 2 & 40 & 4 & 45 & 8 \\
\hline Peanuts sugar coated & Sweet Fatty & 11 & 42 & 4 & 1 & 1 & 4 & 2 & 2 & 1 & 11 & 3 & 41 & 6 \\
\hline Pear with skin & Neutral & 7 & 30 & 2 & 6 & 2 & 1 & 1 & 1 & 1 & 1 & 0 & 10 & 4 \\
\hline Pear without skin & Neutral & 7 & 30 & 3 & 8 & 2 & 1 & 0 & 1 & 1 & 1 & 1 & 9 & 4 \\
\hline Peas and carrots tinned & Neutral & 9 & 13 & 2 & 2 & 1 & 1 & 0 & 8 & 2 & 16 & 3 & 9 & 3 \\
\hline Peas frozen boiled & Neutral & 9 & 15 & 2 & 2 & 1 & 1 & 0 & 5 & 2 & 4 & 2 & 8 & 2 \\
\hline Peppermint & Neutral & 7 & 44 & 5 & 0 & 0 & 1 & 0 & 0 & 0 & 5 & 3 & 2 & 1 \\
\hline Pesto & Savory fatty & 8 & 5 & 2 & 12 & 4 & 2 & 1 & 23 & 7 & 57 & 3 & 54 & 8 \\
\hline Pine nuts & Neutral & 11 & 9 & 2 & 2 & 1 & 6 & 2 & 4 & 2 & 8 & 2 & 40 & 6 \\
\hline Pineapple & Sweet Sour & 11 & 34 & 4 & 34 & 4 & 1 & 0 & 0 & 0 & 2 & 1 & 5 & 3 \\
\hline Pineapple in syrup tinned & Sweet Sour & 9 & 38 & 4 & 20 & 3 & 0 & 0 & 0 & 0 & 3 & 2 & 6 & 2 \\
\hline Pizza margherita (warm) & Savory fatty & 9 & 16 & 2 & 4 & 2 & 1 & 1 & 15 & 5 & 35 & 5 & 35 & 3 \\
\hline Popcorn sweet puffed & Sweet Fatty & 9 & 43 & 3 & 2 & 1 & 1 & 1 & 1 & 1 & 8 & 4 & 21 & 4 \\
\hline
\end{tabular}




\begin{tabular}{|c|c|c|c|c|c|c|c|c|c|c|c|c|c|c|}
\hline \multirow[t]{2}{*}{ Food } & \multirow[t]{2}{*}{ Cluster } & \multirow[t]{2}{*}{$\mathrm{n}$} & \multicolumn{2}{|c|}{ Sweet } & \multicolumn{2}{|l|}{ Sour } & \multicolumn{2}{|c|}{ Bitter } & \multicolumn{2}{|c|}{ Umami } & \multicolumn{2}{|c|}{ Salt } & \multicolumn{2}{|c|}{ Fat } \\
\hline & & & $\mathrm{m}$ & SE & $\mathrm{m}$ & SE & $\mathrm{m}$ & SE & $\mathrm{m}$ & SE & $\mathrm{m}$ & SE & $\mathrm{m}$ & SE \\
\hline Pork chop (pan-fried) & Neutral & 7 & 4 & 2 & 10 & 4 & 1 & 1 & 18 & 5 & 16 & 2 & 25 & 5 \\
\hline Pork fillet (pan-fried) & Neutral & 9 & 5 & 2 & 9 & 3 & 1 & 0 & 14 & 6 & 16 & 3 & 30 & 4 \\
\hline Pork rib chop (pan-fried) & Neutral & 8 & 4 & 2 & 4 & 2 & 0 & 0 & 14 & 4 & 16 & 4 & 21 & 3 \\
\hline Pork schnitzel breaded raw & Savory fatty & 7 & 5 & 2 & 1 & 0 & 1 & 1 & 10 & 2 & 37 & 4 & 46 & 6 \\
\hline Pork schnitzel not breaded (pan-fried) & Neutral & 10 & 5 & 2 & 7 & 2 & 1 & 0 & 16 & 6 & 18 & 3 & 25 & 3 \\
\hline Pork shoarma seasoning (pan-fried) & Savory fatty & 9 & 11 & 3 & 3 & 1 & 0 & 0 & 32 & 7 & 50 & 4 & 59 & 4 \\
\hline Pork shoulder chop (pan-fried) & Savory fatty & 9 & 4 & 2 & 2 & 1 & 0 & 0 & 12 & 5 & 24 & 4 & 47 & 6 \\
\hline Pork sparerib (oven) & Savory fatty & 8 & 15 & 2 & 2 & 1 & 0 & 0 & 29 & 9 & 38 & 5 & 53 & 5 \\
\hline Pork tenderloin (pan-fried) & Neutral & 9 & 4 & 2 & 9 & 3 & 1 & 0 & 14 & 6 & 17 & 3 & 34 & 5 \\
\hline Potato crisps oven baked & Savory fatty & 7 & 15 & 4 & 8 & 3 & 1 & 0 & 18 & 5 & 44 & 3 & 31 & 9 \\
\hline Potato waffles/balls frozen (deep-fried) & Savory fatty & 10 & 7 & 2 & 3 & 1 & 1 & 1 & 13 & 3 & 40 & 3 & 45 & 4 \\
\hline Potatoes boiled with skin average & Neutral & 7 & 6 & 2 & 2 & 1 & 1 & 1 & 8 & 3 & 6 & 2 & 9 & 3 \\
\hline $\begin{array}{l}\text { Potatoes mashed prepared with semi-skimmed } \\
\text { milk and margarine }\end{array}$ & Savory fatty & 10 & 7 & 2 & 3 & 1 & 1 & 0 & 15 & 3 & 44 & 3 & 36 & 5 \\
\hline Potatoes sliced frozen (pan-fried) & Savory fatty & 7 & 6 & 2 & 1 & 1 & 1 & 0 & 13 & 5 & 26 & 4 & 45 & 7 \\
\hline Potatoes without skins boiled average & Neutral & 12 & 5 & 1 & 2 & 1 & 1 & 0 & 7 & 1 & 8 & 1 & 13 & 2 \\
\hline Prawn crackers & Savory fatty & 7 & 12 & 2 & 1 & 1 & 0 & 0 & 26 & 4 & 29 & 5 & 33 & 4 \\
\hline Pretzel sticks & Neutral & 11 & 4 & 2 & 1 & 1 & 1 & 1 & 1 & 0 & 47 & 5 & 9 & 1 \\
\hline Pudding airy average & Sweet Fatty & 10 & 63 & 3 & 9 & 2 & 2 & 1 & 5 & 4 & 8 & 3 & 55 & 3 \\
\hline Pudding semolina with red currant sauce & Sweet Fatty & 8 & 46 & 4 & 10 & 3 & 2 & 1 & 3 & 2 & 6 & 3 & 46 & 2 \\
\hline Pudding vanilla & Sweet Fatty & 8 & 48 & 4 & 2 & 1 & 0 & 0 & 0 & 0 & 4 & 2 & 51 & 3 \\
\hline Puff pastry baked & Neutral & 10 & 3 & 1 & 2 & 1 & 2 & 1 & 1 & 0 & 32 & 3 & 15 & 4 \\
\hline Raisins dried & Sweet Fatty & 9 & 51 & 5 & 11 & 3 & 0 & 0 & 1 & 0 & 2 & 1 & 13 & 2 \\
\hline Raisins soaked in water & Sweet Fatty & 9 & 48 & 4 & 15 & 3 & 0 & 0 & 1 & 1 & 3 & 2 & 17 & 3 \\
\hline Rice brown boiled & Neutral & 10 & 3 & 1 & 2 & 1 & 1 & 1 & 2 & 1 & 3 & 1 & 9 & 2 \\
\hline Rice cakes puffed & Neutral & 8 & 3 & 1 & 0 & 0 & 1 & 1 & 1 & 1 & 7 & 1 & 4 & 1 \\
\hline Rice white boiled & Neutral & 10 & 3 & 0 & 2 & 1 & 2 & 1 & 4 & 2 & 2 & 1 & 5 & 1 \\
\hline Roll brown hard & Neutral & 12 & 6 & 1 & 4 & 1 & 1 & 1 & 1 & 0 & 14 & 2 & 9 & 2 \\
\hline Roll brown soft & Neutral & 12 & 7 & 1 & 4 & 1 & 2 & 1 & 1 & 0 & 13 & 2 & 12 & 2 \\
\hline
\end{tabular}




\begin{tabular}{|c|c|c|c|c|c|c|c|c|c|c|c|c|c|c|}
\hline \multirow[t]{2}{*}{ Food } & \multirow[t]{2}{*}{ Cluster } & \multirow[t]{2}{*}{$\mathrm{n}$} & \multicolumn{2}{|c|}{ Sweet } & \multicolumn{2}{|c|}{ Sour } & \multicolumn{2}{|c|}{ Bitter } & \multicolumn{2}{|c|}{ Umami } & \multicolumn{2}{|c|}{ Salt } & \multicolumn{2}{|c|}{ Fat } \\
\hline & & & $\mathrm{m}$ & SE & $\mathrm{m}$ & SE & $\mathrm{m}$ & SE & $\mathrm{m}$ & SE & $\mathrm{m}$ & SE & $\mathrm{m}$ & SE \\
\hline Roll white hard & Neutral & 12 & 7 & 1 & 3 & 1 & 1 & 0 & 1 & 0 & 14 & 2 & 10 & 2 \\
\hline Roll white soft & Neutral & 12 & 8 & 1 & 4 & 1 & 2 & 1 & 1 & 0 & 13 & 2 & 13 & 3 \\
\hline Roll wholemeal soft & Neutral & 8 & 7 & 1 & 3 & 1 & 2 & 1 & 1 & 1 & 16 & 2 & 10 & 2 \\
\hline Rosti prepared without fat (warm) & Savory fatty & 9 & 9 & 2 & 3 & 2 & 1 & 1 & 15 & 4 & 35 & 1 & 29 & 3 \\
\hline Salad cream $25 \%$ oil & Fatty & 7 & 11 & 3 & 33 & 7 & 2 & 1 & 8 & 4 & 32 & 9 & 68 & 5 \\
\hline Salad dressing honey/mustard & Savory fatty & 7 & 15 & 4 & 41 & 7 & 2 & 2 & 14 & 8 & 40 & 9 & 66 & 2 \\
\hline Salad dressing vinaigrette & Savory fatty & 7 & 10 & 3 & 56 & 8 & 2 & 2 & 11 & 6 & 41 & 10 & 66 & 9 \\
\hline Salami & Savory fatty & 12 & 3 & 1 & 19 & 5 & 1 & 0 & 21 & 6 & 51 & 4 & 56 & 5 \\
\hline Salami sausage saveloy & Savory fatty & 12 & 3 & 1 & 14 & 3 & 1 & 0 & 20 & 5 & 47 & 3 & 58 & 4 \\
\hline Salmon farmed prepared in microwave oven & Neutral & 8 & 3 & 1 & 9 & 3 & 1 & 1 & 25 & 6 & 18 & 2 & 27 & 5 \\
\hline Salmon smoked & Savory fatty & 8 & 3 & 1 & 10 & 4 & 1 & 0 & 36 & 6 & 53 & 3 & 57 & 6 \\
\hline Salmon tinned & Savory fatty & 11 & 4 & 1 & 8 & 2 & 2 & 1 & 28 & 6 & 26 & 3 & 32 & 5 \\
\hline Sandwich meat chicken & Savory fatty & 12 & 4 & 1 & 6 & 2 & 1 & 1 & 17 & 3 & 37 & 3 & 26 & 3 \\
\hline Sandwich spread original & Sweet Sour & 8 & 19 & 3 & 45 & 5 & 1 & 0 & 13 & 5 & 24 & 7 & 36 & 6 \\
\hline Sauce for chips $25 \%$ oil & Fatty & 9 & 12 & 2 & 37 & 5 & 1 & 0 & 8 & 4 & 28 & 6 & 74 & 3 \\
\hline Sauce tomato ready-made jar & Savory fatty & 8 & 20 & 3 & 24 & 6 & 1 & 1 & 33 & 8 & 39 & 6 & 31 & 5 \\
\hline Sausage beef Braadworst (pan-fried) & Savory fatty & 9 & 5 & 2 & 4 & 1 & 1 & 0 & 19 & 7 & 48 & 4 & 58 & 7 \\
\hline Sausage cooked & Savory fatty & 12 & 3 & 1 & 5 & 2 & 0 & 0 & 23 & 4 & 37 & 3 & 47 & 5 \\
\hline Sausage Dutch Frikandel frozen (deep-fried) & Savory fatty & 9 & 9 & 2 & 5 & 2 & 1 & 0 & 21 & 6 & 45 & 6 & 55 & 6 \\
\hline Sausage frankfurter tinned & Savory fatty & 7 & 6 & 3 & 12 & 4 & 1 & 1 & 28 & 7 & 48 & 5 & 55 & 5 \\
\hline Sausage grill & Savory fatty & 8 & 6 & 3 & 8 & 3 & 0 & 0 & 21 & 5 & 39 & 3 & 63 & 5 \\
\hline Sausage luncheon meat & Savory fatty & 12 & 4 & 1 & 8 & 2 & 1 & 0 & 19 & 4 & 37 & 3 & 49 & 5 \\
\hline Sausage pork Braadworst (pan-fried) & Savory fatty & 7 & 6 & 2 & 6 & 3 & 0 & 0 & 24 & 6 & 54 & 5 & 67 & 3 \\
\hline Sausage raw beef & Savory fatty & 7 & 5 & 2 & 13 & 6 & 3 & 2 & 21 & 8 & 42 & 7 & 64 & 3 \\
\hline Sausage smoked beef cooked & Savory fatty & 13 & 4 & 1 & 23 & 4 & 1 & 0 & 27 & 7 & 56 & 4 & 62 & 2 \\
\hline Sausage smoked lean cooked & Savory fatty & 13 & 3 & 1 & 21 & 4 & 1 & 0 & 23 & 5 & 51 & 4 & 54 & 3 \\
\hline Sausage with smoked bacon-bits & Savory fatty & 7 & 7 & 3 & 9 & 3 & 0 & 0 & 32 & 9 & 44 & 4 & 62 & 5 \\
\hline Shrimps Dutch peeled boiled & Savory fatty & 10 & 8 & 2 & 4 & 2 & 1 & 0 & 31 & 3 & 33 & 3 & 31 & 5 \\
\hline
\end{tabular}




\begin{tabular}{|c|c|c|c|c|c|c|c|c|c|c|c|c|c|c|}
\hline \multirow[t]{2}{*}{ Food } & \multirow[t]{2}{*}{ Cluster } & \multirow[t]{2}{*}{$\mathrm{n}$} & \multicolumn{2}{|c|}{ Sweet } & \multicolumn{2}{|c|}{ Sour } & \multicolumn{2}{|c|}{ Bitter } & \multicolumn{2}{|c|}{ Umami } & \multicolumn{2}{|c|}{ Salt } & \multicolumn{2}{|c|}{ Fat } \\
\hline & & & $\mathrm{m}$ & SE & $\mathrm{m}$ & SE & $\mathrm{m}$ & SE & $\mathrm{m}$ & SE & $\mathrm{m}$ & SE & $\mathrm{m}$ & $\mathrm{SE}$ \\
\hline Silver-skin onions sweet pickled glass & Sweet Sour & 8 & 10 & 3 & 53 & 5 & 2 & 1 & 2 & 1 & 12 & 5 & 10 & 4 \\
\hline Smoked sausage- cooked average & Savory fatty & 8 & 6 & 2 & 20 & 3 & 1 & 1 & 18 & 7 & 42 & 6 & 59 & 6 \\
\hline Smoothie fruit & Sweet Sour & 7 & 37 & 4 & 39 & 4 & 3 & 2 & 0 & 0 & 4 & 2 & 15 & 6 \\
\hline Snack sausage roll puff pastry & Savory fatty & 10 & 7 & 2 & 4 & 2 & 1 & 0 & 17 & 6 & 45 & 4 & 55 & 6 \\
\hline Snack sausage roll with bread dough pastry & Savory fatty & 10 & 9 & 3 & 6 & 2 & 1 & 0 & 19 & 7 & 38 & 4 & 31 & 4 \\
\hline Soft drink tonic & Bitter & 8 & 24 & 3 & 22 & 5 & 38 & 8 & 0 & 0 & 2 & 2 & 1 & 0 \\
\hline Soft drink without caffeine & Sweet Sour & 12 & 51 & 3 & 33 & 4 & 6 & 2 & 0 & 0 & 2 & 2 & 3 & 2 \\
\hline Soft drink, Coca-Cola, Light & Sweet Sour & 11 & 46 & 4 & 20 & 6 & 3 & 1 & 0 & 0 & 1 & 1 & 1 & 1 \\
\hline Soft drink, Coca-Cola, Regular & Sweet Sour & 11 & 41 & 5 & 23 & 7 & 5 & 2 & 0 & 0 & 1 & 1 & 1 & 1 \\
\hline Soup clear with meat and vegetables & Savory fatty & 8 & 12 & 3 & 3 & 2 & 1 & 0 & 37 & 9 & 37 & 4 & 24 & 4 \\
\hline Soup clear with meat vegetables and noodles & Savory fatty & 9 & 7 & 2 & 7 & 3 & 1 & 1 & 21 & 5 & 42 & 2 & 22 & 3 \\
\hline Soup cup-a-soup prepared & Savory fatty & 9 & 10 & 3 & 6 & 2 & 3 & 2 & 21 & 6 & 39 & 2 & 25 & 2 \\
\hline Soup legume based ready-made prepared & Savory fatty & 9 & 7 & 2 & 10 & 2 & 2 & 1 & 20 & 5 & 44 & 3 & 37 & 2 \\
\hline Soup main course with legumes and meat & Savory fatty & 13 & 6 & 2 & 8 & 2 & 2 & 1 & 22 & 6 & 40 & 3 & 40 & 3 \\
\hline Soup thickened with meat and vegetables & Savory fatty & 8 & 19 & 3 & 22 & 6 & 1 & 0 & 32 & 9 & 32 & 6 & 20 & 2 \\
\hline Soup vegetable based dried packet prepared & Savory fatty & 12 & 8 & 2 & 3 & 1 & 1 & 0 & 31 & 7 & 45 & 3 & 23 & 4 \\
\hline Soup vegetable based tinned prepared & Savory fatty & 9 & 19 & 2 & 16 & 4 & 1 & 1 & 27 & 7 & 32 & 4 & 26 & 2 \\
\hline Soya sauce sweet & Savory fatty & 10 & 42 & 8 & 9 & 4 & 4 & 3 & 27 & 10 & 61 & 5 & 17 & 6 \\
\hline Spaghetti bolognese & Savory fatty & 8 & 9 & 1 & 11 & 3 & 0 & 0 & 25 & 7 & 29 & 5 & 37 & 4 \\
\hline Spinach creamed frozen boiled & Neutral & 9 & 6 & 2 & 3 & 2 & 2 & 1 & 10 & 4 & 30 & 2 & 16 & 4 \\
\hline Spinach frozen boiled & Neutral & 7 & 7 & 2 & 4 & 2 & 8 & 3 & 3 & 1 & 4 & 2 & 7 & 5 \\
\hline Sports drink AA High Energy & Sweet Sour & 8 & 56 & 4 & 19 & 4 & 1 & 1 & 0 & 0 & 5 & 3 & 3 & 1 \\
\hline Spread chocolade plain & Sweet Fatty & 8 & 66 & 4 & 1 & 1 & 8 & 3 & 0 & 0 & 9 & 4 & 69 & 4 \\
\hline Spread chocolate Duo Penotti hazelnut & Sweet Fatty & 8 & 66 & 4 & 1 & 0 & 2 & 1 & 2 & 1 & 9 & 4 & 70 & 3 \\
\hline Spread chocolate hazelnut & Sweet Fatty & 8 & 63 & 5 & 1 & 0 & 3 & 1 & 3 & 2 & 9 & 4 & 69 & 2 \\
\hline Spread chocolate milk & Sweet Fatty & 8 & 62 & 5 & 1 & 1 & 6 & 2 & 2 & 1 & 10 & 4 & 65 & 3 \\
\hline Spring roll frozen (deep-fried) & Savory fatty & 10 & 11 & 2 & 6 & 2 & 1 & 1 & 26 & 5 & 36 & 4 & 51 & 6 \\
\hline Stock from cube prepared & Savory fatty & 12 & 7 & 2 & 3 & 1 & 1 & 0 & 41 & 8 & 57 & 4 & 21 & 5 \\
\hline
\end{tabular}




\begin{tabular}{|c|c|c|c|c|c|c|c|c|c|c|c|c|c|c|}
\hline \multirow[t]{2}{*}{ Food } & \multirow[t]{2}{*}{ Cluster } & \multirow[t]{2}{*}{$\mathrm{n}$} & \multicolumn{2}{|c|}{ Sweet } & \multicolumn{2}{|c|}{ Sour } & \multicolumn{2}{|c|}{ Bitter } & \multicolumn{2}{|c|}{ Umami } & \multicolumn{2}{|c|}{ Salt } & \multicolumn{2}{|c|}{ Fat } \\
\hline & & & $\mathrm{m}$ & SE & $\mathrm{m}$ & SE & $\mathrm{m}$ & SE & $\mathrm{m}$ & SE & $\mathrm{m}$ & SE & $\mathrm{m}$ & SE \\
\hline Strawberries & Sweet Sour & 12 & 18 & 3 & 34 & 3 & 1 & 0 & 0 & 0 & 1 & 0 & 8 & 3 \\
\hline Sugar granulated, with coffee & Bitter & 11 & 25 & 2 & 5 & 2 & 43 & 6 & 1 & 0 & 1 & 1 & 3 & 2 \\
\hline Sugar granulated, with tea & Neutral & 11 & 20 & 2 & 4 & 1 & 16 & 4 & 0 & 0 & 1 & 1 & 2 & 1 \\
\hline Sunflower seeds & Neutral & 12 & 6 & 2 & 2 & 1 & 3 & 1 & 2 & 1 & 3 & 1 & 23 & 6 \\
\hline Sweet pepper green boiled & Neutral & 9 & 7 & 1 & 5 & 2 & 19 & 3 & 4 & 1 & 3 & 1 & 15 & 7 \\
\hline Sweet pepper red boiled & Neutral & 10 & 14 & 2 & 11 & 3 & 3 & 1 & 4 & 1 & 2 & 1 & 9 & 3 \\
\hline Sweet pepper yellow boiled & Neutral & 9 & 16 & 1 & 8 & 3 & 2 & 1 & 3 & 1 & 3 & 1 & 12 & 4 \\
\hline $\begin{array}{l}\text { Sweetener aspartame/acesulfame } \mathrm{p} \text { tablet, with } \\
\text { coffee }\end{array}$ & Bitter & 7 & 10 & 2 & 2 & & 51 & 7 & 1 & 0 & 2 & 2 & 3 & 2 \\
\hline Sweetener $\mathrm{p}$ tablet Natrena, with coffee & Bitter & 7 & 17 & 2 & 2 & 2 & 46 & 7 & 0 & 0 & 1 & 1 & 4 & 2 \\
\hline Syrup apple & Sweet Fatty & 8 & 64 & 8 & 29 & 5 & 3 & 1 & 1 & 1 & 6 & 4 & 28 & 7 \\
\hline Tapenade olive & Savory fatty & 9 & 9 & 4 & 26 & 4 & 1 & 1 & 32 & 7 & 43 & 5 & 52 & 5 \\
\hline Tarts filled with jam & Sweet Fatty & 8 & 61 & 2 & 10 & 4 & 2 & 1 & 1 & 0 & 11 & 4 & 41 & 4 \\
\hline Tea prepared & Neutral & 11 & 4 & 1 & 5 & 1 & 20 & 4 & 1 & 0 & 1 & 0 & 2 & 2 \\
\hline Tilapia (pan-fried) & Neutral & 7 & 6 & 2 & 5 & 2 & 1 & 0 & 15 & 5 & 12 & 4 & 21 & 5 \\
\hline Toast & Neutral & 8 & 3 & 1 & 1 & 0 & 1 & 0 & 0 & 0 & 9 & 2 & 4 & 1 \\
\hline Toffee with chocolate & Sweet Fatty & 8 & 68 & 1 & 1 & 0 & 3 & 1 & 0 & 0 & 10 & 4 & 64 & 4 \\
\hline Toffees & Sweet Fatty & 8 & 66 & 5 & 1 & 0 & 1 & 1 & 0 & 0 & 11 & 4 & 47 & 5 \\
\hline Tomato average raw & Neutral & 10 & 10 & 1 & 19 & 2 & 3 & 1 & 12 & 2 & 3 & 1 & 10 & 4 \\
\hline Tomato juice & Savory fatty & 9 & 10 & 3 & 23 & 6 & 1 & 1 & 33 & 8 & 32 & 5 & 14 & 4 \\
\hline Tortellini boiled & Neutral & 9 & 8 & 2 & 4 & 1 & 1 & 0 & 15 & 6 & 25 & 4 & 24 & 3 \\
\hline Tuna in oil tinned & Savory fatty & 8 & 3 & 1 & 19 & 6 & 2 & 1 & 31 & 8 & 37 & 4 & 36 & 9 \\
\hline Tuna in water tinned & Neutral & 12 & 4 & 1 & 16 & 2 & 2 & 1 & 22 & 4 & 25 & 3 & 19 & 4 \\
\hline Tuna (pan-fried) & Neutral & 7 & 4 & 2 & 11 & 3 & 1 & 1 & 10 & 3 & 12 & 3 & 13 & 3 \\
\hline Waffle Luikse & Sweet Fatty & 8 & 47 & 5 & 1 & 1 & 0 & 0 & 0 & 0 & 8 & 3 & 24 & 5 \\
\hline Waffle soft-/sugar-/flash- & Sweet Fatty & 8 & 49 & 2 & 1 & 1 & 0 & 0 & 0 & 0 & 9 & 4 & 28 & 4 \\
\hline Waffle syrup average & Sweet Fatty & 12 & 56 & 4 & 1 & 0 & 1 & 0 & 1 & 0 & 8 & 3 & 30 & 4 \\
\hline Walnuts unsalted & Neutral & 7 & 5 & 2 & 1 & 0 & 12 & 2 & 6 & 3 & 2 & 1 & 22 & 4 \\
\hline Water average & Neutral & 11 & 1 & 0 & 1 & 0 & 2 & 1 & 1 & 0 & 1 & 0 & 5 & 3 \\
\hline
\end{tabular}




\begin{tabular}{|c|c|c|c|c|c|c|c|c|c|c|c|c|c|c|}
\hline \multirow{2}{*}{ Food } & \multirow[t]{2}{*}{ Cluster } & \multirow[t]{2}{*}{$\mathrm{n}$} & \multicolumn{2}{|c|}{ Sweet } & \multicolumn{2}{|l|}{ Sour } & \multicolumn{2}{|c|}{ Bitter } & \multicolumn{2}{|c|}{ Umami } & \multicolumn{2}{|c|}{ Salt } & \multicolumn{2}{|c|}{ Fat } \\
\hline & & & $\mathrm{m}$ & SE & $\mathrm{m}$ & SE & $\mathrm{m}$ & SE & $\mathrm{m}$ & $\mathrm{SE}$ & $\mathrm{m}$ & SE & $\mathrm{m}$ & SE \\
\hline Whey drink light Rivella & Sweet Sour & 8 & 35 & 4 & 26 & 6 & 7 & 3 & 1 & 1 & 3 & 2 & 1 & 1 \\
\hline Whey drink Taksi with sugar & Sweet Sour & 7 & 50 & 3 & 29 & 3 & 1 & 1 & 0 & 0 & 5 & 3 & 3 & 1 \\
\hline Whisky & Bitter & 11 & 22 & 7 & 13 & 7 & 25 & 7 & 1 & 0 & 2 & 2 & 4 & 4 \\
\hline White fish fillet in batter deep-fried & Savory fatty & 8 & 5 & 1 & 4 & 2 & 1 & 0 & 27 & 5 & 32 & 5 & 48 & 6 \\
\hline Wine gum with liquorice & Sweet Fatty & 7 & 48 & 6 & 7 & 3 & 1 & 0 & 0 & 0 & 26 & 4 & 21 & 7 \\
\hline Wine gums & Sweet Fatty & 7 & 49 & 4 & 21 & 5 & 0 & 0 & 0 & 0 & 4 & 3 & 22 & 6 \\
\hline Wine red & Bitter & 11 & 8 & 1 & 46 & 4 & 38 & 7 & 2 & 2 & 1 & 1 & 2 & 1 \\
\hline Wine rose & Sweet Sour & 13 & 13 & 2 & 43 & 6 & 24 & 6 & 1 & 0 & 1 & 1 & 1 & 0 \\
\hline Wine white dry & Sweet Sour & 13 & 12 & 3 & 45 & 5 & 21 & 6 & 1 & 1 & 1 & 1 & 1 & 0 \\
\hline Wine white sweet & Sweet Sour & 13 & 16 & 3 & 38 & 5 & 18 & 6 & 1 & 0 & 2 & 1 & 1 & 0 \\
\hline Wrap/Tortilla & Neutral & 7 & 11 & 1 & 1 & 1 & 1 & 1 & 2 & 1 & 11 & 3 & 14 & 3 \\
\hline Yakult Original & Sweet Sour & 12 & 50 & 4 & 38 & 4 & 3 & 1 & 3 & 1 & 3 & 1 & 13 & 3 \\
\hline Yoghurt cream- with fruit & Sweet Fatty & 8 & 40 & 5 & 27 & 2 & 1 & 1 & 1 & 1 & 2 & 1 & 44 & 4 \\
\hline Yoghurt drink & Sweet Sour & 9 & 32 & 3 & 27 & 2 & 1 & 1 & 1 & 1 & 4 & 2 & 29 & 2 \\
\hline Yoghurt drink Vifit fruit & Sweet Sour & 8 & 34 & 3 & 27 & 4 & 0 & 0 & 1 & 1 & 4 & 2 & 26 & 3 \\
\hline Yoghurt drink with sweeteners Optimel & Sweet Sour & 12 & 42 & 4 & 27 & 3 & 2 & 1 & 1 & 0 & 2 & 1 & 24 & 2 \\
\hline Yoghurt full fat & Sweet Sour & 12 & 2 & 1 & 71 & 2 & 2 & 1 & 1 & 0 & 3 & 2 & 28 & 4 \\
\hline Yoghurt full fat stracciatella & Sweet Fatty & 8 & 31 & 6 & 25 & 2 & 5 & 2 & 1 & 1 & 5 & 2 & 43 & 2 \\
\hline Yoghurt full fat with fruit & Sweet Fatty & 9 & 40 & 3 & 28 & 3 & 1 & 0 & 1 & 1 & 4 & 2 & 42 & 3 \\
\hline Yoghurt full fat with fruit/muesli Activia & Sweet Fatty & 11 & 34 & 4 & 20 & 4 & 2 & 1 & 1 & 0 & 4 & 2 & 37 & 2 \\
\hline Yoghurt half fat & Sweet Sour & 12 & 6 & 1 & 49 & 3 & 2 & 1 & 1 & 0 & 1 & 1 & 27 & 3 \\
\hline $\begin{array}{l}\text { Yoghurt low fat with fruit/van with sweeteners } \\
\text { Optimel }\end{array}$ & Sweet Sour & 8 & 33 & 3 & 32 & 3 & 1 & 1 & 1 & 1 & 5 & 3 & 33 & 3 \\
\hline Yoghurt low fat & Sweet Sour & 12 & 2 & 1 & 67 & 3 & 2 & 1 & 1 & 0 & 3 & 1 & 25 & 3 \\
\hline Yoghurt low fat with fruit & Sweet Fatty & 12 & 42 & 4 & 24 & 2 & 1 & 1 & 1 & 0 & 2 & 1 & 33 & 3 \\
\hline Yoghurt vanilla half fat & Sweet Sour & 9 & 26 & 2 & 27 & 3 & 0 & 0 & 1 & 1 & 4 & 2 & 35 & 3 \\
\hline
\end{tabular}


Table S2. Taste database of 423 Malaysian foods. For each food evaluated: Cluster (result of taste classification), number of evaluations (n), mean (m) and standard error (SE) for the five basic tastes and fat sensation

\begin{tabular}{|c|c|c|c|c|c|c|c|c|c|c|c|c|c|c|}
\hline \multirow[t]{2}{*}{ Food } & \multirow[t]{2}{*}{ Cluster } & \multirow[t]{2}{*}{$\mathrm{n}$} & \multicolumn{2}{|c|}{ Sweet } & \multicolumn{2}{|c|}{ Sour } & \multicolumn{2}{|c|}{ Bitter } & \multicolumn{2}{|c|}{ Umami } & \multicolumn{2}{|c|}{ Salt } & \multicolumn{2}{|c|}{ Fat } \\
\hline & & & $\mathrm{m}$ & SE & $\mathrm{m}$ & SE & $\mathrm{m}$ & $\mathrm{SE}$ & $\mathrm{m}$ & SE & $\mathrm{m}$ & SE & $\mathrm{m}$ & SE \\
\hline $\begin{array}{l}\text { Acar (Pickled cucumbers, carrots and pineapple } \\
\text { dish) }\end{array}$ & Sweet Sour & 14 & 16 & 1 & 22 & 2 & 1 & 0 & 2 & 1 & 3 & 1 & 7 & 1 \\
\hline Agar, mixed fruits & Sweet Sour & 14 & 33 & 2 & 23 & 2 & 0 & 0 & 1 & 0 & 1 & 0 & 10 & 2 \\
\hline Agar, pandan with coconut milk & Sweet fatty & 14 & 35 & 2 & 0 & 0 & 0 & 0 & 1 & 0 & 4 & 1 & 11 & 2 \\
\hline Agar, rose syrup & Sweet Sour & 14 & 35 & 2 & 0 & 0 & 0 & 0 & 1 & 1 & 1 & 0 & 8 & 2 \\
\hline Ais kacang, (ice-blended) with rose syrup & Sweet fatty & 12 & 48 & 2 & 1 & 0 & 1 & 0 & 1 & 1 & 2 & 1 & 15 & 3 \\
\hline Alcohol drink $<1 \%$, shandy & Sweet Sour & 12 & 30 & 2 & 25 & 2 & 9 & 2 & 0 & 0 & 0 & 0 & 3 & 1 \\
\hline Alcohol drink $4 \%$, cider, apple & Sweet Sour & 12 & 31 & 2 & 38 & 3 & 13 & 1 & 0 & 0 & 0 & 0 & 3 & 1 \\
\hline Anchovy, fried with sambal & Savory fatty & 12 & 10 & 1 & 6 & 2 & 3 & 1 & 28 & 4 & 57 & 2 & 34 & 2 \\
\hline Apple, green, Granny Smith & Sweet Sour & 20 & 16 & 1 & 51 & 2 & 2 & 0 & 1 & 0 & 1 & 0 & 2 & 0 \\
\hline Apple, red, Gala & Sweet Sour & 20 & 32 & 2 & 22 & 2 & 1 & 0 & 1 & 0 & 0 & 0 & 3 & 1 \\
\hline Banana, fresh, Berangan & Sweet Sour & 20 & 42 & 2 & 7 & 1 & 1 & 0 & 2 & 1 & 1 & 0 & 7 & 1 \\
\hline Bean, baked, canned & Savory fatty & 14 & 19 & 2 & 13 & 2 & 0 & 0 & 20 & 2 & 25 & 2 & 19 & 2 \\
\hline Bean, French, stir fried & Savory fatty & 12 & 9 & 1 & 1 & 0 & 1 & 0 & 18 & 3 & 27 & 2 & 29 & 2 \\
\hline Bean, long, stir fried & Neutral & 12 & 9 & 1 & 1 & 0 & 3 & 1 & 15 & 2 & 21 & 2 & 24 & 3 \\
\hline Bean, sprouts, stir fried & Savory fatty & 12 & 6 & 1 & 0 & 0 & 2 & 1 & 21 & 3 & 24 & 1 & 32 & 3 \\
\hline Beef, Rendang-style & Savory fatty & 13 & 7 & 1 & 3 & 1 & 2 & 1 & 39 & 4 & 44 & 2 & 46 & 2 \\
\hline Beef, cooked in curry & Savory fatty & 13 & 6 & 1 & 2 & 1 & 2 & 1 & 37 & 4 & 32 & 2 & 45 & 3 \\
\hline Beef, cooked with coconut milk & Savory fatty & 12 & 7 & 1 & 12 & 2 & 1 & 1 & 38 & 4 & 36 & 3 & 39 & 3 \\
\hline Beef, cooked with soy sauce & Savory fatty & 13 & 10 & 2 & 2 & 1 & 1 & 0 & 33 & 4 & 34 & 2 & 43 & 3 \\
\hline Beef, fried & Savory fatty & 12 & 4 & 1 & 2 & 1 & 1 & 0 & 24 & 3 & 24 & 2 & 31 & 3 \\
\hline Beef, Paprik-style & Savory fatty & 13 & 20 & 2 & 8 & 2 & 0 & 0 & 36 & 4 & 33 & 2 & 37 & 3 \\
\hline Beef, spiced, grilled & Savory fatty & 14 & 4 & 1 & 3 & 1 & 2 & 1 & 35 & 4 & 27 & 2 & 26 & 3 \\
\hline Beef, stir fried, with turmeric & Savory fatty & 13 & 8 & 2 & 0 & 0 & 1 & 0 & 32 & 4 & 28 & 2 & 33 & 3 \\
\hline Beer 5\% alcohol, Carlsberg & Bitter & 12 & 5 & 1 & 23 & 3 & 53 & 3 & 1 & 1 & 0 & 0 & 3 & 1 \\
\hline
\end{tabular}




\begin{tabular}{|c|c|c|c|c|c|c|c|c|c|c|c|c|c|c|}
\hline \multirow[t]{2}{*}{ Food } & \multirow[t]{2}{*}{ Cluster } & \multirow[t]{2}{*}{$\mathrm{n}$} & \multicolumn{2}{|c|}{ Sweet } & \multicolumn{2}{|c|}{ Sour } & \multicolumn{2}{|c|}{ Bitter } & \multicolumn{2}{|c|}{ Umami } & \multicolumn{2}{|c|}{ Salt } & \multicolumn{2}{|c|}{ Fat } \\
\hline & & & $\mathrm{m}$ & SE & $\mathrm{m}$ & SE & $\mathrm{m}$ & SE & $\mathrm{m}$ & SE & $\mathrm{m}$ & SE & $\mathrm{m}$ & SE \\
\hline Beer 5\% alcohol, Heineken & Bitter & 12 & 5 & 1 & 19 & 3 & 53 & 2 & 0 & 0 & 1 & 0 & 3 & 1 \\
\hline Beer $5 \%$ alcohol, Tiger & Bitter & 12 & 5 & 1 & 20 & 3 & 48 & 3 & 1 & 1 & 0 & 0 & 2 & 1 \\
\hline Bell pepper, stir fried & Neutral & 15 & 5 & 1 & 4 & 1 & 2 & 1 & 12 & 2 & 16 & 1 & 22 & 2 \\
\hline Bitter gourd, cooked with egg and turmeric & Savory fatty & 12 & 4 & 1 & 3 & 1 & 30 & 2 & 23 & 4 & 26 & 2 & 30 & 3 \\
\hline Bread, white, Gardenia & Neutral & 20 & 8 & 1 & 4 & 1 & 1 & 0 & 2 & 1 & 6 & 1 & 7 & 1 \\
\hline Bread, white, Massimo & Neutral & 20 & 9 & 1 & 2 & 1 & 1 & 0 & 3 & 1 & 6 & 1 & 8 & 1 \\
\hline Bread, whole meal, Gardenia & Neutral & 20 & 6 & 1 & 6 & 1 & 3 & 1 & 2 & 1 & 6 & 1 & 5 & 1 \\
\hline Bread, whole meal, Massimo & Neutral & 20 & 5 & 1 & 3 & 1 & 2 & 0 & 2 & 1 & 6 & 1 & 5 & 1 \\
\hline Brinjal, stir fried with sambal & Savory fatty & 12 & 10 & 2 & 1 & 0 & 3 & 1 & 22 & 3 & 26 & 2 & 44 & 3 \\
\hline Broccoli, stir fried & Savory fatty & 12 & 2 & 1 & 0 & 0 & 3 & 1 & 20 & 2 & 33 & 3 & 24 & 2 \\
\hline Bun, kaya & Sweet fatty & 20 & 50 & 2 & 3 & 1 & 1 & 0 & 2 & 1 & 8 & 1 & 21 & 2 \\
\hline Bun, lotus filling, steamed & Sweet fatty & 12 & 49 & 2 & 2 & 1 & 0 & 0 & 2 & 1 & 4 & 1 & 19 & 2 \\
\hline Bun, plain & Neutral & 20 & 19 & 1 & 2 & 1 & 1 & 0 & 1 & 1 & 5 & 1 & 14 & 1 \\
\hline Bun, pork, BBQ, baked & Savory fatty & 12 & 28 & 2 & 1 & 0 & 0 & 0 & 22 & 4 & 30 & 2 & 28 & 2 \\
\hline Bun, pork, BBQ, steamed Char Siew pau & Savory fatty & 12 & 27 & 2 & 2 & 1 & 0 & 0 & 17 & 3 & 27 & 2 & 27 & 1 \\
\hline Bun, pork, steamed Bapau & Savory fatty & 12 & 14 & 2 & 1 & 0 & 0 & 0 & 25 & 4 & 29 & 2 & 31 & 3 \\
\hline Bun, red bean fillings & Sweet fatty & 20 & 39 & 2 & 3 & 1 & 2 & 0 & 2 & 1 & 9 & 1 & 18 & 1 \\
\hline Bun, spicy anchovy filling, Gardenia & Savory fatty & 13 & 11 & 2 & 4 & 1 & 2 & 1 & 19 & 3 & 25 & 2 & 22 & 2 \\
\hline Burger, beef, cheese, McD & Savory fatty & 14 & 6 & 1 & 15 & 2 & 0 & 0 & 27 & 3 & 29 & 2 & 34 & 2 \\
\hline Burger, beef, Ramly & Savory fatty & 13 & 15 & 2 & 13 & 2 & 1 & 0 & 37 & 3 & 31 & 2 & 45 & 3 \\
\hline Burger, chicken, Colonel, KFC & Savory fatty & 12 & 9 & 2 & 9 & 1 & 0 & 0 & 22 & 4 & 33 & 2 & 37 & 3 \\
\hline Burger, chicken, McD & Savory fatty & 12 & 9 & 2 & 11 & 1 & 0 & 0 & 23 & 4 & 33 & 2 & 38 & 3 \\
\hline Burger, chicken, Ramly & Savory fatty & 13 & 17 & 1 & 14 & 2 & 0 & 0 & 32 & 3 & 29 & 2 & 44 & 3 \\
\hline Burger, chicken, Zinger, KFC & Savory fatty & 12 & 8 & 2 & 7 & 1 & 0 & 0 & 26 & 4 & 38 & 2 & 41 & 3 \\
\hline Burger, egg banjo, Ramly & Savory fatty & 13 & 16 & 1 & 11 & 2 & 0 & 0 & 25 & 3 & 24 & 1 & 39 & 3 \\
\hline Burger, fish fillet, $\mathrm{McD}$ & Savory fatty & 12 & 7 & 2 & 20 & 2 & 0 & 0 & 23 & 3 & 30 & 2 & 34 & 3 \\
\hline
\end{tabular}




\begin{tabular}{|c|c|c|c|c|c|c|c|c|c|c|c|c|c|c|}
\hline \multirow[t]{2}{*}{ Food } & \multirow[t]{2}{*}{ Cluster } & \multirow[t]{2}{*}{$\mathrm{n}$} & \multicolumn{2}{|c|}{ Sweet } & \multicolumn{2}{|c|}{ Sour } & \multicolumn{2}{|c|}{ Bitter } & \multicolumn{2}{|c|}{ Umami } & \multicolumn{2}{|c|}{ Salt } & \multicolumn{2}{|c|}{ Fat } \\
\hline & & & $\mathrm{m}$ & SE & $\mathrm{m}$ & SE & $\mathrm{m}$ & $\mathrm{SE}$ & $\mathrm{m}$ & SE & $\mathrm{m}$ & SE & $\mathrm{m}$ & SE \\
\hline Burger, Roti John & Savory fatty & 12 & 9 & 1 & 4 & 1 & 0 & 0 & 24 & 3 & 29 & 2 & 33 & 2 \\
\hline Cabbage, Siew Pak Choy, stir fried & Savory fatty & 12 & 2 & 0 & 0 & 0 & 10 & 1 & 14 & 2 & 23 & 2 & 28 & 3 \\
\hline Cabbage, stir fried & Savory fatty & 12 & 7 & 1 & 0 & 0 & 2 & 1 & 21 & 3 & 25 & 2 & 38 & 3 \\
\hline Cabbage, turmeric, mamak style, stir fried & Neutral & 12 & 4 & 1 & 4 & 1 & 1 & 0 & 6 & 1 & 24 & 2 & 18 & 3 \\
\hline Cake, banana & Sweet fatty & 12 & 42 & 2 & 3 & 1 & & 0 & 1 & 1 & 3 & 1 & 25 & 3 \\
\hline Cake, brown sugar, steamed & Neutral & 12 & 29 & 2 & 1 & 1 & 0 & 0 & 2 & 1 & 8 & 1 & 15 & 1 \\
\hline Cake, butter & Sweet fatty & 12 & 40 & 2 & 2 & 1 & 0 & 0 & 1 & 0 & 4 & 1 & 31 & 3 \\
\hline Cake, chocolate & Sweet fatty & 14 & 43 & 3 & 1 & 0 & 2 & 1 & 4 & 1 & 6 & 1 & 31 & 3 \\
\hline Cake, fruit & Sweet fatty & 14 & 51 & 3 & 12 & 2 & 1 & 0 & 4 & 1 & 6 & 1 & 31 & 2 \\
\hline Cake, layered, original, Apollo & Sweet fatty & 12 & 55 & 2 & 6 & 2 & 0 & 0 & 1 & 5 & 2 & 1 & 28 & 2 \\
\hline Cake, sponge, Chinese style & Sweet fatty & 12 & 35 & 2 & 1 & 0 & 0 & 0 & 0 & 0 & 4 & 1 & 13 & 2 \\
\hline Cake, sponge, Massimo & Sweet fatty & 13 & 39 & 2 & 1 & 0 & 0 & 0 & 1 & 1 & 4 & 1 & 23 & 2 \\
\hline Calamari ring, fried & Savory fatty & 12 & 3 & 1 & 5 & 2 & 1 & 0 & 20 & 3 & 42 & 2 & 38 & 4 \\
\hline Candy, black current-flavored & Sweet Sour & 13 & 43 & 2 & 17 & 2 & 0 & 0 & 1 & 1 & 0 & 0 & 9 & 2 \\
\hline Candy, caramel & Sweet fatty & 13 & 54 & 2 & 2 & 1 & 2 & 1 & 0 & 0 & 4 & 1 & 36 & 3 \\
\hline Candy, chocolate, milk, M\&Ms & Sweet fatty & 13 & 56 & 2 & 0 & 0 & 3 & 1 & 0 & 0 & 5 & 1 & 38 & 3 \\
\hline Candy, chocolate, peanut, M\&Ms & Sweet fatty & 20 & 59 & 3 & 0 & 0 & 4 & 2 & 2 & 1 & 6 & 2 & 41 & 4 \\
\hline Candy, ice lemon tea-flavored & Sweet Sour & 13 & 38 & 3 & 14 & 2 & 2 & 1 & 1 & 0 & 2 & 1 & 5 & 1 \\
\hline Candy, Kopiko & Sweet Sour & 13 & 40 & 2 & 2 & 1 & 12 & 2 & 1 & 1 & 0 & 0 & 7 & 1 \\
\hline Candy, mint, chocolate-filled & Sweet fatty & 13 & 45 & 3 & 1 & 1 & 2 & 1 & 0 & 0 & 0 & 0 & 18 & 3 \\
\hline Candy, mint, Mentos & Sweet Sour & 13 & 42 & 2 & 1 & 1 & 4 & 2 & 1 & 0 & 0 & 0 & 6 & 1 \\
\hline Cauliflower, stir fried & Savory fatty & 13 & 6 & 1 & 1 & 0 & 2 & 1 & 16 & 3 & 28 & 2 & 27 & 3 \\
\hline Cereal beverage, 3 in 1, Nestum & Neutral & 13 & 25 & 1 & 2 & 1 & 0 & 0 & 0 & 0 & 3 & 1 & 10 & 2 \\
\hline Cereal beverage, 3 in 1, with oats, Nestum & Neutral & 13 & 17 & 1 & 1 & 0 & 0 & 0 & 1 & 1 & 2 & 0 & 12 & 2 \\
\hline Chicken, spiced, grilled & Savory fatty & 12 & 5 & 1 & 2 & 1 & 1 & 0 & 28 & 4 & 28 & 2 & 36 & 3 \\
\hline
\end{tabular}




\begin{tabular}{|c|c|c|c|c|c|c|c|c|c|c|c|c|c|c|}
\hline \multirow[t]{2}{*}{ Food } & \multirow[t]{2}{*}{ Cluster } & \multirow[t]{2}{*}{$\mathrm{n}$} & \multicolumn{2}{|c|}{ Sweet } & \multicolumn{2}{|c|}{ Sour } & \multicolumn{2}{|c|}{ Bitter } & \multicolumn{2}{|c|}{ Umami } & \multicolumn{2}{|c|}{ Salt } & \multicolumn{2}{|c|}{ Fat } \\
\hline & & & $\mathrm{m}$ & SE & $\mathrm{m}$ & SE & $\mathrm{m}$ & SE & $\mathrm{m}$ & SE & $\mathrm{m}$ & SE & $\mathrm{m}$ & SE \\
\hline Chicken ball, fried & Savory fatty & 12 & 5 & 1 & 1 & 0 & 0 & 0 & 22 & 3 & 29 & 2 & 27 & 2 \\
\hline Chicken, cooked with soy sauce & Savory fatty & 13 & 18 & 2 & 13 & 2 & 0 & 0 & 28 & 4 & 32 & 2 & 34 & 2 \\
\hline Chicken, curry & Savory fatty & 12 & 4 & 1 & 2 & 1 & 1 & 0 & 33 & 4 & 32 & 2 & 47 & 2 \\
\hline Chicken, fried, original, KFC & Savory fatty & 13 & 3 & 1 & 0 & 0 & 0 & 0 & 21 & 4 & 30 & 2 & 46 & 3 \\
\hline Chicken, fried, spiced, mamak style & Savory fatty & 13 & 5 & 1 & 2 & 1 & 0 & 0 & 16 & 3 & 28 & 3 & 37 & 3 \\
\hline Chicken, fried, spicy, KFC & Savory fatty & 13 & 4 & 1 & 0 & 0 & 0 & 0 & 28 & 4 & 33 & 2 & 50 & 3 \\
\hline Chicken, Kurma & Savory fatty & 13 & 9 & 2 & 1 & 1 & 1 & 0 & 36 & 4 & 34 & 2 & 41 & 3 \\
\hline Chicken, masak merah (Malay-style) & Savory fatty & 13 & 14 & 2 & 1 & 0 & 0 & 0 & 28 & 4 & 35 & 2 & 33 & 2 \\
\hline Chicken, meatball, boiled & Savory fatty & 12 & 5 & 1 & 1 & 0 & 0 & 0 & 24 & 4 & 27 & 2 & 21 & 2 \\
\hline Chicken, Paprik-style & Savory fatty & 13 & 19 & 2 & 12 & 2 & 0 & 0 & 27 & 4 & 28 & 2 & 30 & 2 \\
\hline Chicken, Rendang & Savory fatty & 12 & 11 & 1 & 4 & 1 & 2 & 1 & 39 & 4 & 38 & 2 & 43 & 2 \\
\hline Chicken, stir fried, with turmeric & Savory fatty & 13 & 7 & 1 & 3 & 1 & 2 & 1 & 26 & 4 & 34 & 2 & 30 & 2 \\
\hline Chicken, sweet and sour & Savory fatty & 12 & 27 & 2 & 26 & 1 & 0 & 0 & 31 & 3 & 28 & 2 & 38 & 2 \\
\hline Chickpeas, boiled & Neutral & 14 & 7 & 1 & 2 & 1 & 0 & 0 & 6 & 1 & 21 & 2 & 9 & 2 \\
\hline Chinese cabbage, Pak-choy, stir fried & Savory fatty & 12 & 2 & 1 & 3 & 1 & 6 & 1 & 8 & 2 & 38 & 2 & 36 & 3 \\
\hline Chinese kale, Kailan, stir fried & Savory fatty & 12 & 2 & 1 & 1 & 0 & 4 & 1 & 13 & 2 & 26 & 2 & 34 & 3 \\
\hline Chinese kale, Kailan, stir fried with salted fish & Savory fatty & 12 & 2 & 1 & 1 & 1 & 2 & 1 & 18 & 3 & 40 & 2 & 37 & 3 \\
\hline Chips, banana, original & Neutral & 14 & 9 & 2 & 1 & 0 & 1 & 0 & 7 & 2 & 23 & 2 & 21 & 2 \\
\hline Chips, potato, original, Mister Potato & Savory fatty & 15 & 7 & 1 & 1 & 0 & 1 & 0 & 8 & 2 & 36 & 2 & 23 & 1 \\
\hline Chips, tapioca, original & Neutral & 14 & 5 & 2 & 1 & 0 & 4 & 1 & 5 & 1 & 30 & 2 & 19 & 2 \\
\hline Chips, tapioca, spicy & Sweet fatty & 14 & 33 & 2 & 2 & 1 & 0 & 0 & 5 & 1 & 18 & 2 & 22 & 2 \\
\hline Chocolate, bar, Kit Kat & Sweet fatty & 15 & 64 & 2 & 0 & 0 & 3 & 1 & 0 & 0 & 5 & 1 & 49 & 3 \\
\hline Chocolate, bar, malted, Cloud9 & Sweet fatty & 13 & 53 & 2 & 1 & 0 & 2 & 1 & 0 & 0 & 12 & 2 & 53 & 2 \\
\hline Chocolate, milk, bar & Sweet fatty & 13 & 66 & 2 & 0 & 0 & 8 & 2 & 1 & 1 & 4 & 1 & 65 & 2 \\
\hline Cockle, stir fried, with sambal & Savory fatty & 14 & 9 & 1 & 4 & 1 & 5 & 1 & 40 & 3 & 32 & 2 & 29 & 2 \\
\hline Coffee, 3 in 1, Nescafe & Bitter & 20 & 25 & 1 & 1 & 0 & 34 & 2 & 1 & 1 & 0 & 0 & 11 & 2 \\
\hline
\end{tabular}




\begin{tabular}{|c|c|c|c|c|c|c|c|c|c|c|c|c|c|c|}
\hline \multirow[t]{2}{*}{ Food } & \multirow[t]{2}{*}{ Cluster } & \multirow[t]{2}{*}{$\mathrm{n}$} & \multicolumn{2}{|c|}{ Sweet } & \multicolumn{2}{|c|}{ Sour } & \multicolumn{2}{|c|}{ Bitter } & \multicolumn{2}{|c|}{ Umami } & \multicolumn{2}{|c|}{ Salt } & \multicolumn{2}{|c|}{ Fat } \\
\hline & & & $\mathrm{m}$ & SE & $\mathrm{m}$ & SE & $\mathrm{m}$ & SE & $\mathrm{m}$ & SE & $\mathrm{m}$ & SE & $\mathrm{m}$ & SE \\
\hline Coffee, canned, Nescafe & Bitter & 13 & 32 & 2 & 4 & 1 & 42 & 3 & 0 & 0 & 3 & 1 & 9 & 2 \\
\hline Coffee, with condensed milk & Bitter & 20 & 41 & 2 & 2 & 1 & 31 & 2 & 1 & 0 & 1 & 0 & 14 & 2 \\
\hline Coffee, with sugar & Sweet Sour & 20 & 59 & 2 & 2 & 1 & 26 & 3 & 1 & 1 & 0 & 0 & 6 & 1 \\
\hline Coleslaw, KFC & Neutral & 13 & 15 & 2 & 8 & 1 & 4 & 1 & 8 & 3 & 11 & 1 & 22 & 2 \\
\hline Cookies, chocolate chips, Chipsmore & Sweet fatty & 14 & 48 & 2 & 1 & 1 & 6 & 1 & 1 & 0 & 8 & 2 & 28 & 2 \\
\hline Cordial, blackcurrant, Ribena & Sweet Sour & 15 & 47 & 2 & 31 & 2 & 1 & 0 & 0 & 0 & 1 & 1 & 4 & 2 \\
\hline Cordial, orange, Sunquick & Sweet Sour & 15 & 22 & 2 & 44 & 2 & 4 & 1 & 0 & 0 & 3 & 1 & 4 & 1 \\
\hline Corn snack, BBQ-flavored, Twisties & Savory fatty & 13 & 5 & 1 & 5 & 2 & 1 & 0 & 25 & 2 & 36 & 2 & 12 & 2 \\
\hline Corn snack, cheese-flavored, Chezeels & Savory fatty & 14 & 5 & 2 & 4 & 1 & 0 & 0 & 43 & 2 & 38 & 1 & 20 & 2 \\
\hline Corn snack, chicken-flavored, Twisties & Savory fatty & 13 & 6 & 1 & 1 & 1 & 0 & 0 & 26 & 3 & 29 & 3 & 14 & 2 \\
\hline Corn, baby, stir fried with mixed vegetables & Savory fatty & 12 & 10 & 1 & 2 & 1 & 1 & 0 & 21 & 3 & 23 & 1 & 27 & 2 \\
\hline Crab ball, breaded, fried & Savory fatty & 12 & 7 & 1 & 2 & 1 & 0 & 0 & 41 & 3 & 26 & 3 & 28 & 2 \\
\hline Crab stick & Savory fatty & 12 & 7 & 1 & 1 & 0 & 0 & 0 & 48 & 3 & 17 & 3 & 16 & 2 \\
\hline Crab, cooked in chili & Savory fatty & 14 & 13 & 2 & 4 & 1 & 1 & 0 & 35 & 3 & 25 & 2 & 30 & 3 \\
\hline Crab, cooked in coconut milk & Savory fatty & 14 & 6 & 1 & 3 & 1 & 1 & 0 & 43 & 3 & 33 & 2 & 34 & 3 \\
\hline Cracker peanuts snack & Savory fatty & 13 & 10 & 2 & 0 & 0 & 1 & 0 & 20 & 3 & 20 & 1 & 25 & 3 \\
\hline Cracker, prawn & Savory fatty & 13 & 5 & 1 & 1 & 1 & 2 & 1 & 29 & 2 & 24 & 2 & 21 & 2 \\
\hline Cracker, prawn, Rota & Savory fatty & 14 & 4 & 1 & 0 & 0 & 0 & 0 & 48 & 1 & 28 & 2 & 18 & 2 \\
\hline Crackers, chocolate-sandwiched, Munchy's & Sweet fatty & 12 & 34 & 3 & 1 & 1 & 1 & 1 & 2 & 1 & 18 & 2 & 30 & 2 \\
\hline Crackers, cream, coated with sugars, Munchy's & Neutral & 13 & 22 & 2 & 0 & 0 & 0 & 0 & 2 & 1 & 11 & 1 & 18 & 2 \\
\hline Crackers, cream, Hup Seng & Neutral & 20 & 3 & 1 & 1 & 0 & 0 & 0 & 1 & 1 & 17 & 1 & 14 & 1 \\
\hline Crackers, cream, Hwa Tai & Neutral & 20 & 3 & 1 & 1 & 0 & 1 & 0 & 2 & 1 & 19 & 1 & 17 & 1 \\
\hline Crackers, cream, vegetable-flavored, Munchy's & Neutral & 12 & 11 & 1 & 0 & 0 & 0 & 0 & 4 & 1 & 18 & 1 & 21 & 1 \\
\hline Crackers, fish (ikan Tambun) & Savory fatty & 12 & 2 & 1 & 0 & 0 & 1 & 0 & 31 & 3 & 22 & 2 & 23 & 2 \\
\hline Crackers, fish, original, Cap Pinggan & Savory fatty & 12 & 2 & 1 & 0 & 0 & 0 & 0 & 40 & 4 & 24 & 2 & 16 & 2 \\
\hline Crackers, fish, sweet and spicy & Sweet fatty & 12 & 34 & 2 & 1 & 1 & 0 & 0 & 20 & 3 & 24 & 3 & 21 & 2 \\
\hline
\end{tabular}




\begin{tabular}{|c|c|c|c|c|c|c|c|c|c|c|c|c|c|c|}
\hline \multirow[t]{2}{*}{ Food } & \multirow[t]{2}{*}{ Cluster } & \multirow[t]{2}{*}{$\mathrm{n}$} & \multicolumn{2}{|c|}{ Sweet } & \multicolumn{2}{|c|}{ Sour } & \multicolumn{2}{|c|}{ Bitter } & \multicolumn{2}{|c|}{ Umami } & \multicolumn{2}{|c|}{ Salt } & \multicolumn{2}{|c|}{ Fat } \\
\hline & & & $\mathrm{m}$ & SE & $\mathrm{m}$ & SE & $\mathrm{m}$ & SE & $\mathrm{m}$ & SE & $\mathrm{m}$ & SE & $\mathrm{m}$ & SE \\
\hline Crackers, peanut-butter sandwiched, Julie & Sweet fatty & 12 & 35 & 3 & 0 & 0 & 0 & 0 & 2 & 1 & 22 & 2 & 36 & 2 \\
\hline Crackers, sandwiched, Oreo & Sweet fatty & 12 & 50 & 3 & 1 & 0 & 2 & 1 & 0 & 0 & 8 & 2 & 31 & 3 \\
\hline Custard, corn-flavored & Sweet fatty & 12 & 42 & 2 & 1 & 0 & 0 & 0 & 2 & 1 & 1 & 0 & 13 & 2 \\
\hline Custard, strawberry-flavored & Sweet fatty & 12 & 44 & 2 & 1 & 0 & 0 & 0 & 1 & 1 & 0 & 0 & 12 & 2 \\
\hline Custard, vanilla-flavored & Sweet fatty & 12 & 40 & 2 & 0 & 0 & 0 & 0 & 2 & 1 & 0 & 0 & 13 & 2 \\
\hline Cuttlefish, cooked with sambal & Savory fatty & 12 & 17 & 1 & 10 & 2 & 1 & 0 & 33 & 3 & 31 & 2 & 33 & 2 \\
\hline Date, kurma, dried & Sweet fatty & 12 & 56 & 3 & 4 & 1 & 2 & 1 & 4 & 1 & 2 & 1 & 15 & 2 \\
\hline $\begin{array}{l}\text { Dim sum, Lo mai kai (glutinous rice, with chicken, } \\
\text { steamed) }\end{array}$ & Savory fatty & 14 & 15 & 1 & 1 & 1 & 2 & 0 & 38 & 3 & 30 & 2 & 40 & 2 \\
\hline Dim sum, pork, steamed Siew mai & Savory fatty & 12 & 7 & 1 & 1 & 0 & 0 & 0 & 31 & 4 & 30 & 2 & 31 & 2 \\
\hline $\begin{array}{l}\text { Dim Sum, yam cake, steamed, with savory chili } \\
\text { sauce }\end{array}$ & Savory fatty & 12 & 12 & 1 & 3 & 1 & 0 & 0 & 12 & 2 & 33 & 2 & 32 & 2 \\
\hline Drink, barley & Sweet Sour & 12 & 28 & 2 & 0 & 0 & 0 & 0 & 2 & 1 & 1 & 0 & 3 & 1 \\
\hline Drink, energy, Livita & Sweet Sour & 12 & 34 & 2 & 45 & 4 & 6 & 2 & 1 & 0 & 3 & 1 & 2 & 1 \\
\hline Drink, energy, Redbull & Sweet Sour & 12 & 43 & 3 & 44 & 4 & 4 & 1 & 1 & 0 & 2 & 1 & 2 & 1 \\
\hline Drink, grass jelly Cincau & Sweet Sour & 12 & 48 & 2 & 0 & 0 & 1 & 0 & 4 & 1 & 1 & 0 & 3 & 1 \\
\hline Drink, lime & Sweet Sour & 12 & 33 & 3 & 32 & 2 & 1 & 0 & 0 & 0 & 0 & 0 & 2 & 1 \\
\hline Drink, packet, Chrysanthemum & Sweet Sour & 13 & 42 & 2 & 0 & 0 & 2 & 1 & 1 & 1 & 1 & 0 & 0 & 0 \\
\hline Drink, packet, lychee & Sweet Sour & 12 & 49 & 2 & 12 & 2 & 0 & 0 & 1 & 1 & 1 & 0 & 6 & 2 \\
\hline Durian & Sweet fatty & 13 & 43 & 3 & 4 & 2 & 6 & 1 & 6 & 2 & 4 & 1 & 24 & 4 \\
\hline Eggs, hen, braised & Savory fatty & 12 & 6 & 1 & 2 & 1 & 1 & 1 & 25 & 3 & 30 & 2 & 19 & 2 \\
\hline Eggs, hen, fried & Savory fatty & 13 & 1 & 1 & 0 & 0 & 0 & 0 & 17 & 3 & 12 & 2 & 35 & 3 \\
\hline Eggs, hen, hard boiled & Neutral & 20 & 2 & 0 & 0 & 0 & 1 & 0 & 13 & 2 & 9 & 1 & 13 & 2 \\
\hline Eggs, hen, omelet & Savory fatty & 12 & 8 & 1 & 1 & 1 & 1 & 0 & 13 & 3 & 39 & 2 & 27 & 2 \\
\hline Eggs, salted & Savory fatty & 15 & 1 & 0 & 4 & 1 & 1 & 0 & 16 & 2 & 62 & 2 & 15 & 2 \\
\hline Fish "satay" snack & Neutral & 12 & 20 & 2 & 2 & 1 & 1 & 0 & 22 & 3 & 17 & 2 & 21 & 3 \\
\hline Fish ball, fried & Savory fatty & 13 & 4 & 1 & 0 & 0 & 0 & 0 & 35 & 3 & 35 & 3 & 25 & 3 \\
\hline
\end{tabular}




\begin{tabular}{|c|c|c|c|c|c|c|c|c|c|c|c|c|c|c|}
\hline \multirow[t]{2}{*}{ Food } & \multirow[t]{2}{*}{ Cluster } & \multirow[t]{2}{*}{$\mathrm{n}$} & \multicolumn{2}{|c|}{ Sweet } & \multicolumn{2}{|c|}{ Sour } & \multicolumn{2}{|c|}{ Bitter } & \multicolumn{2}{|c|}{ Umami } & \multicolumn{2}{|c|}{ Salt } & \multicolumn{2}{|c|}{ Fat } \\
\hline & & & $\mathrm{m}$ & SE & $\mathrm{m}$ & SE & $\mathrm{m}$ & SE & $\mathrm{m}$ & SE & $\mathrm{m}$ & SE & $\mathrm{m}$ & SE \\
\hline Fish, African bream, cooked in coconut milk & Savory fatty & 15 & 4 & 1 & 8 & 1 & 1 & 0 & 34 & 3 & 39 & 2 & 33 & 3 \\
\hline Fish, African bream, fried in chili & Savory fatty & 15 & 8 & 1 & 8 & 1 & 1 & 0 & 34 & 3 & 32 & 2 & 31 & 3 \\
\hline Fish, black pomfret, fried & Savory fatty & 12 & 3 & 1 & 1 & 1 & 2 & 1 & 29 & 3 & 35 & 2 & 27 & 2 \\
\hline Fish, black pomfret, fried in chili & Savory fatty & 13 & 6 & 1 & 8 & 2 & 1 & 0 & 29 & 3 & 32 & 2 & 29 & 2 \\
\hline Fish, catfish, cooked with coconut milk & Savory fatty & 12 & 4 & 1 & 4 & 1 & 1 & 0 & 36 & 4 & 32 & 2 & 38 & 3 \\
\hline Fish, catfish, fried & Savory fatty & 12 & 4 & 1 & 0 & 0 & $1)$ & 0 & 21 & 2 & 23 & 2 & 34 & 3 \\
\hline Fish, catfish, fried with chili & Savory fatty & 14 & 7 & 1 & 6 & 1 & 1 & 0 & 33 & 3 & 34 & 2 & 37 & 2 \\
\hline Fish, Hairtail scad, cooked with soy sauce & Savory fatty & 15 & 8 & 1 & 2 & 1 & 1 & 0 & 33 & 3 & 32 & 2 & 35 & 3 \\
\hline Fish, Hairtail scad, fried in chili & Savory fatty & 12 & 13 & 1 & 11 & 2 & 1 & 0 & 34 & 3 & 33 & 2 & 29 & 2 \\
\hline Fish, Indian mackerel, canned, black bean sauce & Savory fatty & 13 & 3 & 1 & 3 & 1 & 1 & 0 & 47 & 3 & 49 & 2 & 31 & 4 \\
\hline Fish, Indian mackerel, cooked in tamarind & Savory fatty & 12 & 4 & 1 & 11 & 2 & 2 & 1 & 37 & 3 & 37 & 2 & 35 & 2 \\
\hline Fish, Indian mackerel, cooked with Tauchoo & Savory fatty & 15 & 6 & 1 & 5 & 1 & 1 & 0 & 35 & 3 & 44 & 2 & 37 & 3 \\
\hline Fish, Indian mackerel, fried & Savory fatty & 12 & 2 & 1 & 3 & 1 & 4 & 1 & 33 & 3 & 34 & 2 & 28 & 2 \\
\hline Fish, mackerel, Spanish, cooked in curry & Savory fatty & 12 & 4 & 1 & 23 & 2 & 1 & 0 & 20 & 4 & 38 & 2 & 32 & 3 \\
\hline Fish, sardine, canned, in tomato sauce, with bread & Savory fatty & 14 & 5 & 1 & 3 & 1 & 1 & 0 & 30 & 2 & 25 & 2 & 24 & 2 \\
\hline Fish, sardine, canned, tomato sauce & Savory fatty & 13 & 6 & 1 & 9 & 2 & 2 & 1 & 43 & 3 & 28 & 2 & 28 & 3 \\
\hline Fish, sweet and sour & Savory fatty & 13 & 28 & 2 & 16 & 2 & 0 & 0 & 28 & 3 & 27 & 2 & 32 & 2 \\
\hline Fish, tuna, canned, mayonnaise, with bread & Savory fatty & 13 & 6 & 1 & 10 & 2 & 0 & 0 & 25 & 2 & 22 & 2 & 19 & 2 \\
\hline Fish, tuna, cooked in coconut milk & Savory fatty & 14 & 4 & 1 & 8 & 2 & 1 & 0 & 34 & 3 & 31 & 2 & 32 & 3 \\
\hline Fish, tuna, cooked in curry & Savory fatty & 14 & 4 & 1 & 8 & 1 & 1 & 0 & 35 & 3 & 31 & 2 & 40 & 3 \\
\hline Fish, yellow-banded travelly, cooked in tamarind & Savory fatty & 14 & 3 & 1 & 14 & 2 & 1 & 0 & 34 & 3 & 35 & 2 & 42 & 4 \\
\hline French fries, original, KFC & Savory fatty & 13 & 5 & 2 & 0 & 0 & 0 & 0 & 13 & 3 & 25 & 2 & 30 & 2 \\
\hline French fries, original, $\mathrm{McD}$ & Neutral & 13 & 4 & 1 & 3 & 1 & 1 & 1 & 8 & 2 & 21 & 2 & 30 & 3 \\
\hline French fries, with chili sauce, KFC & Savory fatty & 13 & 18 & 2 & 9 & 2 & 0 & 0 & 14 & 3 & 25 & 2 & 30 & 2 \\
\hline French fries, with chili sauce, $\mathrm{McD}$ & Neutral & 13 & 17 & 2 & 9 & 2 & 1 & 0 & 11 & 3 & 22 & 1 & 28 & 3 \\
\hline French fries, with tomato ketchup, KFC & Savory fatty & 13 & 16 & 2 & 24 & 3 & 0 & 0 & 19 & 3 & 24 & 2 & 29 & 2 \\
\hline
\end{tabular}




\begin{tabular}{|c|c|c|c|c|c|c|c|c|c|c|c|c|c|c|}
\hline \multirow[t]{2}{*}{ Food } & \multirow[t]{2}{*}{ Cluster } & \multirow[t]{2}{*}{$\mathrm{n}$} & \multicolumn{2}{|c|}{ Sweet } & \multicolumn{2}{|c|}{ Sour } & \multicolumn{2}{|c|}{ Bitter } & \multicolumn{2}{|c|}{ Umami } & \multicolumn{2}{|c|}{ Salt } & \multicolumn{2}{|c|}{ Fat } \\
\hline & & & $\mathrm{m}$ & SE & $\mathrm{m}$ & SE & $\mathrm{m}$ & SE & $\mathrm{m}$ & SE & $\mathrm{m}$ & SE & $\mathrm{m}$ & SE \\
\hline French fries, with tomato ketchup, McD & Savory fatty & 13 & 16 & 2 & 26 & 2 & 1 & 0 & 21 & 2 & 23 & 2 & 30 & 2 \\
\hline Gizzard, chicken, cooked in sambal & Savory fatty & 14 & 10 & 1 & 2 & 1 & 5 & 1 & 23 & 3 & 26 & 2 & 31 & 3 \\
\hline $\begin{array}{l}\text { Glutinous rice, turmeric, Nasi kunyit with curry } \\
\text { chicken }\end{array}$ & Savory fatty & 14 & 8 & 1 & 2 & 1 & 1 & 0 & 27 & 3 & 35 & 2 & 38 & 2 \\
\hline Glutinous rice, with durian and coconut milk & Sweet fatty & 14 & 41 & 3 & 3 & 1 & 3 & 1 & 2 & 1 & 15 & 2 & 35 & 2 \\
\hline Glutinous rice, with mango and coconut milk & Sweet fatty & 14 & 39 & 2 & 8 & 1 & 0 & 0 & 3 & 1 & 16 & 2 & 35 & 2 \\
\hline Gourd bottle, stir fried & Savory fatty & 12 & 9 & 1 & 4 & 1 & 1 & 0 & 24 & 3 & 24 & 2 & 26 & 3 \\
\hline Grape, purple & Sweet Sour & 20 & 34 & 2 & 8 & 1 & 4 & 1 & 1 & 0 & 1 & 0 & 2 & 0 \\
\hline Grape, red & Sweet Sour & 20 & 39 & 2 & 11 & 1 & 2 & 0 & 1 & 0 & 1 & 0 & 3 & 1 \\
\hline Groundnuts, Cap Tangan & Neutral & 12 & 3 & 1 & 0 & 0 & 2 & 1 & 13 & 3 & 14 & 2 & 13 & 2 \\
\hline Guava, dried & Neutral & 15 & 16 & 2 & 28 & 2 & 1 & 0 & 3 & 1 & 12 & 2 & 8 & 1 \\
\hline Guava, fresh & Sweet Sour & 20 & 15 & 1 & 25 & 2 & 3 & 1 & 2 & 1 & 2 & 0 & 2 & 1 \\
\hline $\begin{array}{l}\text { Guava, fresh, with preserved prune powder Asam } \\
\text { buoy }\end{array}$ & Sweet Sour & 12 & 28 & 2 & 37 & 2 & 3 & 1 & 1 & 1 & 10 & 2 & 4 & 1 \\
\hline Honey dew, fresh & Neutral & 12 & 20 & 2 & 2 & 1 & 1 & 0 & 0 & 0 & 0 & 0 & 4 & 1 \\
\hline Ice cream, chocolate-flavored & Sweet fatty & 12 & 52 & 2 & 0 & 0 & 3 & 1 & 0 & 0 & 0 & 0 & 44 & 3 \\
\hline Ice cream, red bean & Sweet fatty & 14 & 49 & 3 & 0 & 0 & 1 & 0 & 2 & 1 & 6 & 1 & 24 & 3 \\
\hline Ice cream, strawberry-flavored & Sweet fatty & 12 & 57 & 2 & 2 & 1 & 0 & 0 & 0 & 0 & 0 & 0 & 41 & 3 \\
\hline Ice cream, Sundae, $\mathrm{McD}$ & Sweet fatty & 12 & 56 & 3 & 0 & 0 & 0 & 0 & 0 & 0 & 0 & 0 & 44 & 4 \\
\hline Ice cream, vanilla-flavored & Sweet fatty & 12 & 54 & 2 & 0 & 0 & 0 & 0 & 0 & 0 & 0 & 0 & 43 & 3 \\
\hline Ice cream, yam-flavored & Sweet fatty & 14 & 52 & 2 & 0 & 0 & 1 & 0 & 2 & 1 & 4 & 1 & 26 & 3 \\
\hline Isotonic drink, 100 plus, original & Sweet Sour & 15 & 32 & 2 & 20 & 3 & 2 & 1 & 0 & 0 & 7 & 1 & 4 & 1 \\
\hline Jackfruit, dried & Sweet Sour & 12 & 35 & 2 & 7 & 2 & 0 & 0 & 2 & 1 & 2 & 1 & 8 & 2 \\
\hline Jackfruits, fresh & Sweet Sour & 13 & 28 & 2 & 6 & 2 & 1 & 0 & 3 & 1 & 2 & 1 & 6 & 1 \\
\hline Jam, pineapple, with bread & Sweet Sour & 14 & 48 & 3 & 21 & 3 & 0 & 0 & 1 & 0 & 3 & 1 & 18 & 2 \\
\hline Jam, Seri kaya, with bread & Neutral & 13 & 28 & 2 & 2 & 1 & 0 & 0 & 0 & 0 & 9 & 2 & 16 & 2 \\
\hline Jam, strawberry, with bread & Sweet Sour & 14 & 48 & 3 & 21 & 3 & 0 & 0 & 3 & 2 & 6 & 1 & 18 & 2 \\
\hline
\end{tabular}




\begin{tabular}{|c|c|c|c|c|c|c|c|c|c|c|c|c|c|c|}
\hline \multirow[t]{2}{*}{ Food } & \multirow[t]{2}{*}{ Cluster } & \multirow[t]{2}{*}{$\mathrm{n}$} & \multicolumn{2}{|c|}{ Sweet } & \multicolumn{2}{|c|}{ Sour } & \multicolumn{2}{|c|}{ Bitter } & \multicolumn{2}{|c|}{ Umami } & \multicolumn{2}{|c|}{ Salt } & \multicolumn{2}{|c|}{ Fat } \\
\hline & & & $\mathrm{m}$ & SE & $\mathrm{m}$ & SE & $\mathrm{m}$ & SE & $\mathrm{m}$ & SE & $\mathrm{m}$ & SE & $\mathrm{m}$ & SE \\
\hline Juice, apple, Marigold Peel Fresh & Sweet Sour & 13 & 46 & 2 & 31 & 3 & 1 & 0 & 1 & 1 & 2 & 1 & 4 & 1 \\
\hline Juice, guava, Marigold Peel Fresh & Sweet Sour & 12 & 42 & 2 & 29 & 2 & 0 & 0 & 1 & 1 & 1 & 1 & 7 & 2 \\
\hline Juice, mango, Marigold Peel Fresh & Sweet Sour & 13 & 42 & 2 & 32 & 3 & 1 & 0 & 2 & 1 & 3 & 1 & 6 & 1 \\
\hline Juice, orange, Marigold Peel Fresh & Sweet Sour & 12 & 36 & 2 & 41 & 2 & 4 & 1 & 1 & 0 & 1 & 0 & 3 & 1 \\
\hline Juice, orange, Tropicana Twister & Sweet Sour & 12 & 46 & 2 & 35 & 2 & 2 & 1 & 0 & 0 & 1 & 0 & 4 & 1 \\
\hline Kuih, Ang ku kueh, green bean filling & Sweet fatty & 12 & 38 & 1 & 1 & 0 & 1 & 0 & 2 & 1 & 11 & 1 & 21 & 2 \\
\hline Kuih, Ang ku kueh, peanut filling & Sweet fatty & 12 & 46 & 0 & 1 & 1 & 1 & 0 & 3 & 1 & 19 & 2 & 26 & 2 \\
\hline Kuih, Apam ауи & Sweet fatty & 13 & 30 & 2 & 5 & 1 & 1 & 0 & 2 & 1 & 21 & 2 & 20 & 2 \\
\hline Kuih, Apam kukus & Sweet Sour & 12 & 29 & 3 & 9 & 2 & 0 & 0 & 1 & 0 & 3 & 1 & 8 & 1 \\
\hline Kuih, Cekodok pisang & Sweet fatty & 13 & 34 & 3 & 7 & 1 & 1 & 1 & 1 & 1 & 11 & 2 & 36 & 2 \\
\hline Kuih, Cucur udang (no sauce) & Savory fatty & 13 & 4 & 1 & 2 & 1 & 2 & 1 & 24 & 3 & 29 & 2 & 36 & 2 \\
\hline Kuih, Cucur udang, with sweet chili sauce & Savory fatty & 12 & 24 & 2 & 16 & 3 & 1 & 0 & 24 & 3 & 24 & 3 & 33 & 2 \\
\hline Kuih, dodol (Sweet confection with palm sugar) & Sweet fatty & 13 & 53 & 2 & 1 & 0 & 2 & 1 & 4 & 1 & 9 & 2 & 27 & 3 \\
\hline $\begin{array}{l}\text { Kuih, dodol durian (Sweet confection with durian } \\
\text { flavors) }\end{array}$ & Sweet fatty & 13 & 50 & 3 & 2 & 1 & 1 & 0 & 4 & 1 & 9 & 1 & 26 & 3 \\
\hline Kuih, donut, coated with sugar & Sweet fatty & 14 & 39 & 2 & 1 & 0 & 0 & 0 & 1 & 1 & 7 & 1 & 27 & 3 \\
\hline Kuih, Hamchi Peng, with glutinous rice fillings & Savory fatty & 12 & 16 & 1 & 1 & 1 & 0 & 0 & 5 & 2 & 22 & 1 & 38 & 2 \\
\hline Kuih, Hamchi Peng, with red bean fillings & Sweet fatty & 12 & 30 & 2 & 1 & 1 & 0 & 0 & 3 & 1 & 14 & 1 & 37 & 2 \\
\hline Kuih, kapit & Sweet fatty & 14 & 34 & 2 & 0 & 0 & 0 & 0 & 3 & 1 & 4 & 1 & 13 & 2 \\
\hline Kuih, karipap (curry puff) & Savory fatty & 13 & 16 & 1 & 1 & 1 & 1 & 0 & 12 & 2 & 24 & 2 & 33 & 2 \\
\hline Kuih, Keropok Lekor, with sweet chili sauce & Savory fatty & 13 & 23 & 2 & 5 & 1 & 1 & 1 & 41 & 3 & 35 & 2 & 29 & 3 \\
\hline Kuih, ketayap & Sweet fatty & 13 & 52 & 2 & 4 & 1 & 0 & 0 & 3 & 1 & 11 & 2 & 23 & 3 \\
\hline Kuih, lapis & Sweet fatty & 14 & 37 & 2 & 1 & 1 & 0 & 0 & 0 & 0 & 5 & 1 & 26 & 3 \\
\hline Kuih, Onde-onde & Sweet fatty & 13 & 50 & 3 & 1 & 1 & 2 & 1 & 2 & 1 & 9 & 1 & 19 & 2 \\
\hline Kuih, pisang goreng (Fried banana) & Sweet fatty & 13 & 32 & 2 & 8 & 1 & 2 & 1 & 1 & 1 & 10 & 1 & 41 & 3 \\
\hline Kuih, pulut panggang & Savory fatty & 13 & 15 & 2 & 3 & 1 & 1 & 1 & 17 & 3 & 25 & 2 & 31 & 3 \\
\hline
\end{tabular}




\begin{tabular}{|c|c|c|c|c|c|c|c|c|c|c|c|c|c|c|}
\hline \multirow[t]{2}{*}{ Food } & \multirow[t]{2}{*}{ Cluster } & \multirow[t]{2}{*}{$\mathrm{n}$} & \multicolumn{2}{|c|}{ Sweet } & \multicolumn{2}{|c|}{ Sour } & \multicolumn{2}{|c|}{ Bitter } & \multicolumn{2}{|c|}{ Umami } & \multicolumn{2}{|c|}{ Salt } & \multicolumn{2}{|c|}{ Fat } \\
\hline & & & $\mathrm{m}$ & SE & $\mathrm{m}$ & SE & $\mathrm{m}$ & SE & $\mathrm{m}$ & SE & $\mathrm{m}$ & SE & $\mathrm{m}$ & SE \\
\hline $\begin{array}{l}\text { Kuih, Rempeyek (deep-fried savory cracker with } \\
\text { peanuts) }\end{array}$ & Neutral & 13 & 6 & 1 & 0 & 0 & 2 & 0 & 13 & 2 & 21 & 2 & 24 & 4 \\
\hline Kuih, Seri Muka & Sweet fatty & 14 & 37 & 2 & 2 & 1 & 0 & 0 & 5 & 2 & 9 & 2 & 29 & 3 \\
\hline Kuih, Talam & Sweet fatty & 12 & 41 & 3 & 1 & 0 & 0 & 0 & 2 & 1 & 36 & 2 & 31 & 4 \\
\hline kuih, Yau Char Kue & Neutral & 13 & 6 & 1 & 1 & 1 & 1 & 0 & 3 & 1 & 16 & 2 & 29 & 3 \\
\hline Lady's finger, stir fried & Savory fatty & 12 & 4 & 1 & 0 & 0 & 2 & 1 & 24 & 3 & 26 & 2 & 38 & 3 \\
\hline Lamb chop & Savory fatty & 13 & 11 & 2 & 5 & 1 & 2 & 1 & 36 & 4 & 38 & 3 & 41 & 3 \\
\hline Liver, chicken, cooked with sambal & Savory fatty & 14 & 11 & 1 & 3 & 1 & 15 & 2 & 27 & 3 & 25 & 2 & 34 & 3 \\
\hline Liver, chicken, cooked with turmeric & Savory fatty & 14 & 2 & 1 & 1 & 0 & 16 & 2 & 24 & 3 & 20 & 3 & 20 & 2 \\
\hline Lolly ice, orange-flavored & Sweet Sour & 12 & 31 & 2 & 34 & 3 & 0 & 0 & 1 & 1 & 0 & 0 & 2 & 1 \\
\hline Lolly ice, rose syrup-flavored & Sweet Sour & 12 & 39 & 3 & 0 & 0 & 0 & 0 & 1 & 1 & 0 & 0 & 2 & 1 \\
\hline Longan, canned, in syrup & Sweet Sour & 12 & 53 & 2 & 8 & 2 & 0 & 0 & 2 & 1 & 1 & 0 & 4 & 1 \\
\hline Longan, fresh & Sweet Sour & 13 & 43 & 2 & 3 & 1 & 0 & 0 & 2 & 1 & 1 & 1 & 6 & 2 \\
\hline Loofah, cooked in coconut milk & Savory fatty & 12 & 13 & 2 & 0 & 0 & 4 & 1 & 28 & 4 & 28 & 2 & 34 & 3 \\
\hline Lungs, beef, fried in chili & Savory fatty & 14 & 7 & 1 & 2 & 1 & 4 & 1 & 23 & 3 & 26 & 2 & 31 & 3 \\
\hline Lychee, canned, in syrup & Sweet Sour & 13 & 43 & 3 & 19 & 2 & 0 & 0 & 1 & 1 & 1 & 0 & 6 & 1 \\
\hline Malted drink, 3 in 1, Horlick & Sweet fatty & 20 & 35 & 2 & 2 & 1 & 1 & 0 & 2 & 1 & 4 & 1 & 20 & 2 \\
\hline Malted drink, chocolate, Ovaltine & Sweet fatty & 13 & 37 & 3 & 0 & 0 & 4 & 1 & 2 & 1 & 1 & 1 & 17 & 3 \\
\hline Malted drink, chocolate-flavored, Vico & Neutral & 13 & 24 & 2 & 0 & 0 & 7 & 1 & 1 & 1 & 2 & 1 & 16 & 3 \\
\hline Malted drink, Milo, with condensed milk & Sweet fatty & 20 & 51 & 2 & 1 & 0 & 5 & 1 & 2 & 1 & 1 & 0 & 17 & 2 \\
\hline Malted drink, packet, Milo & Sweet fatty & 20 & 50 & 2 & 2 & 1 & 5 & 1 & 3 & 1 & 2 & 1 & 22 & 2 \\
\hline Mandarin, green, local & Sweet Sour & 20 & 20 & 1 & 42 & 2 & 3 & 0 & 1 & 0 & 1 & 0 & 2 & 0 \\
\hline Mandarin, imported, Chinese & Sweet Sour & 20 & 31 & 2 & 32 & 2 & 3 & 1 & 1 & 0 & 1 & 0 & 3 & 1 \\
\hline Mango, dried & Sweet Sour & 12 & 43 & 2 & 25 & 3 & 0 & 0 & 2 & 1 & 1 & 1 & 8 & 2 \\
\hline Mango, fresh, Chok Anan & Sweet Sour & 12 & 42 & 2 & 15 & 2 & 2 & 1 & 0 & 0 & 0 & 0 & 5 & 2 \\
\hline Milk, pasteurized, low fat & Neutral & 12 & 17 & 2 & 4 & 1 & 0 & 0 & 2 & 1 & 3 & 1 & 29 & 3 \\
\hline
\end{tabular}




\begin{tabular}{|c|c|c|c|c|c|c|c|c|c|c|c|c|c|c|}
\hline \multirow[t]{2}{*}{ Food } & \multirow[t]{2}{*}{ Cluster } & \multirow[t]{2}{*}{$\mathrm{n}$} & \multicolumn{2}{|c|}{ Sweet } & \multicolumn{2}{|c|}{ Sour } & \multicolumn{2}{|c|}{ Bitter } & \multicolumn{2}{|c|}{ Umami } & \multicolumn{2}{|c|}{ Salt } & \multicolumn{2}{|c|}{ Fat } \\
\hline & & & $\mathrm{m}$ & $\mathrm{SE}$ & $\mathrm{m}$ & SE & $\mathrm{m}$ & SE & $\mathrm{m}$ & SE & $\mathrm{m}$ & SE & $\mathrm{m}$ & $\mathrm{SE}$ \\
\hline Milk, powder, Anlene & Neutral & 12 & 20 & 2 & 2 & 1 & 1 & 0 & 1 & 6 & 2 & 1 & 26 & 3 \\
\hline Milk, powder, low fat & Neutral & 12 & 16 & 1 & 1 & 1 & 0 & 0 & 1 & 1 & 2 & 1 & 28 & 3 \\
\hline Milk, soy bean, Drinho & Sweet fatty & 20 & 34 & 2 & 1 & 0 & 1 & 0 & 3 & 1 & 2 & 0 & 18 & 2 \\
\hline Milk, soy bean, Yeo's & Sweet fatty & 20 & 41 & 2 & 1 & 0 & 1 & 0 & 2 & 1 & 1 & 0 & 15 & 2 \\
\hline Milk, UHT, chocolate & Sweet fatty & 12 & 45 & 3 & 1 & 1 & 4 & 1 & 0 & 0 & 2 & 1 & 32 & 3 \\
\hline Milk, UHT, full cream & Neutral & 12 & 15 & 1 & 3 & 1 & 0 & 0 & 1 & 0 & 3 & 1 & 28 & 3 \\
\hline Murtabak, chicken, with red onion sauce & Savory fatty & 14 & 12 & 1 & 21 & 2 & 3 & 1 & 30 & 3 & 34 & 2 & 33 & 3 \\
\hline Mushroom, oyster, spiced, deep-fried & Savory fatty & 12 & 2 & 1 & 2 & 1 & 2 & 1 & 16 & 3 & 47 & 2 & 43 & 3 \\
\hline Mushroom, oyster, stir fried & Savory fatty & 12 & 5 & 1 & 1 & 1 & 3 & 1 & 33 & 3 & 20 & 2 & 29 & 3 \\
\hline Mushroom, Shitake, stir fried with Siew Pak-choy & Savory fatty & 12 & 5 & 1 & 1 & 1 & 3 & 1 & 26 & 3 & 21 & 2 & 17 & 2 \\
\hline Mushroom, Shitake, stir fried with soy sauce & Savory fatty & 12 & 5 & 1 & 1 & 1 & 3 & 1 & 35 & 4 & 26 & 2 & 20 & 2 \\
\hline Mustard leaves, choy-sam, stir fried & Neutral & 13 & 2 & 0 & 1 & 0 & 26 & 2 & 7 & 1 & 25 & 1 & 22 & 2 \\
\hline Mutton, cooked in curry & Savory fatty & 14 & 10 & 2 & 5 & 2 & 1 & 1 & 33 & 3 & 40 & 2 & 44 & 3 \\
\hline Noodles, Bandung-style & Savory fatty & 12 & 10 & 1 & 6 & 1 & 0 & 0 & 40 & 3 & 29 & 2 & 34 & 3 \\
\hline Noodles, curry & Savory fatty & 12 & 8 & 1 & 3 & 1 & 1 & 0 & 31 & 4 & 35 & 2 & 47 & 4 \\
\hline Noodles, dry, with soy sauce & Neutral & 12 & 4 & 1 & 0 & 0 & 2 & 1 & 7 & 2 & 20 & 1 & 25 & 3 \\
\hline Noodles, instant, chicken flavored & Savory fatty & 13 & 3 & 1 & 1 & 0 & 0 & 0 & 37 & 3 & 40 & 3 & 18 & 3 \\
\hline Noodles, instant, curry flavored & Savory fatty & 13 & 4 & 1 & 8 & 2 & 1 & 0 & 33 & 4 & 34 & 3 & 17 & 2 \\
\hline Noodles, instant, dry, Sedap & Savory fatty & 13 & 7 & 1 & 2 & 1 & 1 & 1 & 32 & 3 & 26 & 2 & 20 & 2 \\
\hline Noodles, instant, fried, mamak style & Savory fatty & 13 & 6 & 2 & 1 & 0 & 0 & 0 & 20 & 2 & 29 & 2 & 23 & 2 \\
\hline Noodles, instant, snack, BBQ flavored, Mamee & Savory fatty & 12 & 5 & 1 & 2 & 1 & 0 & 0 & 28 & 4 & 30 & 2 & 14 & 2 \\
\hline Noodles, instant, snack, chicken flavored, Mamee & Savory fatty & 12 & 4 & 1 & 1 & 0 & 0 & 0 & 25 & 3 & 31 & 2 & 13 & 2 \\
\hline Noodles, instant, tomyam flavored & Savory fatty & 13 & 4 & 1 & 32 & 3 & 1 & 0 & 34 & 4 & 36 & 3 & 20 & 3 \\
\hline Noodles, Mihun, fried & Savory fatty & 12 & 4 & 1 & 0 & 0 & 2 & 1 & 14 & 2 & 31 & 2 & 32 & 2 \\
\hline Noodles, Mihun, soup & Savory fatty & 13 & 3 & 1 & 4 & 1 & 1 & 0 & 28 & 4 & 27 & 1 & 27 & 2 \\
\hline
\end{tabular}




\begin{tabular}{|c|c|c|c|c|c|c|c|c|c|c|c|c|c|c|}
\hline \multirow[t]{2}{*}{ Food } & \multirow[t]{2}{*}{ Cluster } & \multirow[t]{2}{*}{$\mathrm{n}$} & \multicolumn{2}{|c|}{ Sweet } & \multicolumn{2}{|c|}{ Sour } & \multicolumn{2}{|c|}{ Bitter } & \multicolumn{2}{|c|}{ Umami } & \multicolumn{2}{|c|}{ Salt } & \multicolumn{2}{|c|}{ Fat } \\
\hline & & & $\mathrm{m}$ & SE & $\mathrm{m}$ & SE & $\mathrm{m}$ & SE & $\mathrm{m}$ & SE & $\mathrm{m}$ & SE & $\mathrm{m}$ & SE \\
\hline Noodles, prawn Mee udang & Savory fatty & 12 & 14 & 1 & 2 & 1 & 2 & 0 & 39 & 4 & 24 & 2 & 37 & 3 \\
\hline $\begin{array}{l}\text { Noodles, rice, fried in egg gravy, Cantonese- style } \\
\text { Wa tan hor }\end{array}$ & Savory fatty & 13 & 6 & 1 & 3 & 1 & 1 & 0 & 34 & 3 & 29 & 2 & 34 & 3 \\
\hline Noodles, rice, Kиеу Teow, fried & Savory fatty & 12 & 2 & 1 & 3 & 1 & 1 & 0 & 18 & 3 & 33 & 2 & 39 & 2 \\
\hline Noodles, rice, Киеу Teow, soup & Savory fatty & 13 & 3 & 1 & 5 & 1 & 1 & 0 & 27 & 3 & 28 & 1 & 30 & 2 \\
\hline Noodles, rice, Laksa, asam, Penang-style & Savory fatty & 12 & 6 & 1 & 24 & 2 & 2 & 1 & 32 & 4 & 31 & 2 & 30 & 3 \\
\hline $\begin{array}{l}\text { Noodles, rice, Laksam, with shredded vegetables } \\
\text { and spicy coconut milk sauce }\end{array}$ & Savory fatty & 12 & 9 & 1 & 5 & 1 & 4 & 1 & 21 & 3 & 25 & 2 & 37 & 3 \\
\hline Noodles, Yee Mee, Cantonese-style & Savory fatty & 13 & 5 & 1 & 2 & 1 & 1 & 0 & 41 & 3 & 37 & 3 & 32 & 3 \\
\hline Noodles, yellow, fried & Savory fatty & 12 & 3 & 1 & 2 & 1 & 3 & 1 & 18 & 3 & 41 & 3 & 38 & 2 \\
\hline Nugget, chicken, Ayamas & Savory fatty & 14 & 3 & 1 & 1 & 0 & 1 & 0 & 22 & 3 & 34 & 2 & 34 & 2 \\
\hline Nugget, chicken, Ramly & Savory fatty & 13 & 5 & 1 & 3 & 1 & 0 & 0 & 29 & 3 & 30 & 2 & 28 & 2 \\
\hline Orange, fresh, Sunkist & Sweet Sour & 20 & 28 & 2 & 36 & 2 & 5 & 1 & 1 & 0 & 1 & 0 & 3 & 1 \\
\hline Papaya, fresh & Sweet Sour & 20 & 31 & 2 & 2 & 0 & 2 & 0 & 2 & 1 & 1 & 0 & 3 & 1 \\
\hline $\begin{array}{l}\text { Pastry, Beh Teh Soh, with sticky maltose sugar } \\
\text { fillings }\end{array}$ & Sweet fatty & 12 & 34 & 2 & 3 & 1 & 0 & 0 & 4 & 1 & 19 & 2 & 21 & 1 \\
\hline Pastry, cream puff & Sweet fatty & 13 & 35 & 2 & 1 & 0 & 0 & 0 & 2 & 1 & 13 & 2 & 42 & 2 \\
\hline $\begin{array}{l}\text { Pastry, Lao Po Beng, with winter melon and } \\
\text { almond paste fillings }\end{array}$ & Sweet fatty & 12 & 41 & 2 & 1 & 0 & 0 & 0 & 2 & 1 & 13 & 1 & 22 & 1 \\
\hline $\begin{array}{l}\text { Pastry, Tau Sar Piah, with savory green bean } \\
\text { fillings }\end{array}$ & Sweet fatty & 12 & 31 & 2 & 2 & 1 & 0 & 0 & 3 & 1 & 26 & 2 & 20 & 2 \\
\hline Pear, fresh & Sweet Sour & 12 & 32 & 2 & 1 & 0 & 0 & 0 & 1 & 0 & 0 & 0 & 3 & 1 \\
\hline Peas, snow, stir fried & Neutral & 12 & 8 & 2 & 0 & 0 & 2 & 0 & 17 & 3 & 16 & 1 & 25 & 3 \\
\hline Pineapple, canned, in syrup & Sweet Sour & 13 & 52 & 2 & 29 & 2 & 0 & 0 & 2 & 1 & 2 & 1 & 6 & 1 \\
\hline Pineapple, fresh & Sweet Sour & 20 & 21 & 2 & 50 & 2 & 0 & 0 & 1 & 1 & 2 & 1 & 2 & 0 \\
\hline Pizza, beef pepperoni, Domino & Savory fatty & 14 & 10 & 2 & 13 & 2 & 1 & 0 & 34 & 3 & 31 & 2 & 40 & 2 \\
\hline Pizza, beef pepperoni, Pizza Hut & Savory fatty & 14 & 8 & 1 & 8 & 1 & 0 & 0 & 32 & 3 & 33 & 2 & 38 & 2 \\
\hline Pizza, chicken pepperoni, Domino & Savory fatty & 12 & 9 & 1 & 16 & 2 & 1 & 0 & 28 & 3 & 33 & 2 & 32 & 2 \\
\hline
\end{tabular}




\begin{tabular}{|c|c|c|c|c|c|c|c|c|c|c|c|c|c|c|}
\hline \multirow[t]{2}{*}{ Food } & \multirow[t]{2}{*}{ Cluster } & \multirow[t]{2}{*}{$\mathrm{n}$} & \multicolumn{2}{|c|}{ Sweet } & \multicolumn{2}{|c|}{ Sour } & \multicolumn{2}{|c|}{ Bitter } & \multicolumn{2}{|c|}{ Umami } & \multicolumn{2}{|c|}{ Salt } & \multicolumn{2}{|c|}{ Fat } \\
\hline & & & $\mathrm{m}$ & SE & $\mathrm{m}$ & SE & $\mathrm{m}$ & SE & $\mathrm{m}$ & SE & $\mathrm{m}$ & SE & $\mathrm{m}$ & SE \\
\hline Pizza, Hawaiian chicken, Pizza Hut & Savory fatty & 13 & 16 & 1 & 18 & 2 & 1 & 0 & 30 & 3 & 31 & 2 & 34 & 2 \\
\hline Pizza, seafood, Domino & Savory fatty & 12 & 8 & 1 & 12 & 2 & 0 & 0 & 26 & 3 & 31 & 2 & 32 & 2 \\
\hline Pizza, seafood, Pizza Hut & Savory fatty & 13 & 17 & 1 & 13 & 2 & 0 & 0 & 39 & 3 & 29 & 2 & 35 & 3 \\
\hline $\begin{array}{l}\text { Pork, Ba kut teh (Cooked in broth with spice and } \\
\text { herb) }\end{array}$ & Savory fatty & 12 & 7 & 1 & 2 & 1 & 4 & 1 & 26 & 4 & 32 & 2 & 39 & 2 \\
\hline Pork, BBQ Chinese style, Char Siew & Savory fatty & 12 & 24 & 2 & 1 & 0 & 0 & 0 & 25 & 4 & 28 & 2 & 33 & 2 \\
\hline Pork, braised & Savory fatty & 12 & 6 & 1 & 1 & $1 /$ & 4 & 1 & 24 & 3 & 35 & 2 & 52 & 3 \\
\hline Pork, cooked with preserved vegetables & Savory fatty & 12 & 6 & 1 & 13 & 2 & 1 & 0 & 40 & 4 & 50 & 2 & 49 & 3 \\
\hline Pork, dried, Chinese, $B a K w a$ & Savory fatty & 12 & 23 & 2 & 1 & 1 & 1 & 0 & 22 & 3 & 28 & 3 & 32 & 2 \\
\hline Pork, leg, cooked with soy sauce and vinegar & Savory fatty & 12 & 10 & 1 & 24 & 2 & 1 & 0 & 14 & 3 & 27 & 2 & 53 & 3 \\
\hline Pork, luncheon & Savory fatty & 12 & 3 & 1 & 5 & 2 & 0 & 0 & 28 & 3 & 38 & 2 & 4 & 2 \\
\hline Pork, minced, steamed with eggs & Savory fatty & 12 & 6 & 1 & 0 & 0 & 0 & 0 & 27 & 3 & 36 & 2 & 37 & 2 \\
\hline Pork, minced, stir fried with egg tofu & Savory fatty & 12 & 9 & 1 & 2 & 1 & 0 & 0 & 32 & 4 & 33 & 2 & 32 & 2 \\
\hline Pork, minced, stir fried with soy sauce & Savory fatty & 12 & 13 & 2 & 2 & 1 & 0 & 0 & 27 & 4 & 39 & 2 & 44 & 3 \\
\hline Pork, roasted & Savory fatty & 12 & 4 & 1 & 1 & 0 & 1 & 0 & 18 & 4 & 46 & 2 & 44 & 3 \\
\hline Pork, roll, spiced, fried Lobak & Savory fatty & 12 & 8 & 1 & 2 & 1 & 0 & 0 & 35 & 3 & 38 & 2 & 32 & 1 \\
\hline Pork, stir fried with ginger onion & Savory fatty & 12 & 6 & 0 & 1 & 1 & 1 & 0 & 28 & 4 & 32 & 2 & 30 & 2 \\
\hline Pork, sweet and sour & Savory fatty & 12 & 28 & 1 & 30 & 1 & 0 & 0 & 27 & 4 & 30 & 2 & 33 & 2 \\
\hline Porridge, black glutinous rice, with coconut milk & Sweet fatty & 14 & 36 & 2 & 0 & 0 & 1 & 0 & 5 & 1 & 5 & 1 & 22 & 2 \\
\hline Porridge, green bean, with coconut milk & Sweet fatty & 14 & 33 & 2 & 3 & 1 & 1 & 0 & 4 & 1 & 13 & 2 & 20 & 2 \\
\hline Porridge, red bean, with coconut milk & Sweet fatty & 14 & 39 & 2 & 1 & 1 & 1 & 0 & 4 & 1 & 11 & 2 & 21 & 2 \\
\hline Potato, cooked in curry & Savory fatty & 12 & 11 & 1 & 2 & 1 & 1 & 1 & 21 & 3 & 28 & 1 & 38 & 3 \\
\hline Potato, mashed, KFC & Savory fatty & 13 & 7 & 1 & 2 & 1 & 0 & 0 & 34 & 4 & 32 & 2 & 29 & 3 \\
\hline Potato, stir fried with sambal & Savory fatty & 12 & 15 & 1 & 3 & 1 & 0 & 0 & 26 & 3 & 24 & 2 & 33 & 2 \\
\hline Potato, sweet, fried & Sweet fatty & 13 & 27 & 2 & 3 & 1 & 1 & 0 & 6 & 2 & 17 & 1 & 28 & 2 \\
\hline Prawn, cooked with sambal & Savory fatty & 12 & 19 & 2 & 5 & 1 & 1 & 0 & 31 & 4 & 26 & 2 & 33 & 2 \\
\hline
\end{tabular}




\begin{tabular}{|c|c|c|c|c|c|c|c|c|c|c|c|c|c|c|}
\hline \multirow[t]{2}{*}{ Food } & \multirow[t]{2}{*}{ Cluster } & \multirow[t]{2}{*}{$\mathrm{n}$} & \multicolumn{2}{|c|}{ Sweet } & \multicolumn{2}{|c|}{ Sour } & \multicolumn{2}{|c|}{ Bitter } & \multicolumn{2}{|c|}{ Umami } & \multicolumn{2}{|c|}{ Salt } & \multicolumn{2}{|c|}{ Fat } \\
\hline & & & $\mathrm{m}$ & SE & $\mathrm{m}$ & SE & $\mathrm{m}$ & SE & $\mathrm{m}$ & SE & $\mathrm{m}$ & SE & $\mathrm{m}$ & SE \\
\hline Prawn, cooked with stinky bean and sambal & Savory fatty & 12 & 11 & 1 & 5 & 1 & 4 & 1 & 36 & 3 & 22 & 2 & 32 & 2 \\
\hline Prune, dried & Sweet Sour & 12 & 31 & 2 & 25 & 3 & 1 & 0 & 2 & 1 & 2 & 1 & 16 & 2 \\
\hline Pumpkin, stir fried & Neutral & 12 & 13 & 2 & 0 & 0 & 0 & 0 & 18 & 3 & 17 & 1 & 26 & 3 \\
\hline Raisin & Sweet Sour & 15 & 33 & 1 & 18 & 2 & 1 & 0 & 1 & 0 & 1 & 0 & 7 & 1 \\
\hline Rambutan, fresh & Sweet Sour & 13 & 33 & 2 & 10 & 2 & 1 & 0 & 1 & 0 & 1 & 1 & 5 & 1 \\
\hline Rice porridge, chicken & Savory fatty & 12 & 4 & 1 & 2 & 1 & 0 & 0 & 26 & 3 & 46 & 3 & 24 & 2 \\
\hline Rice porridge, chicken, $\mathrm{McD}$ & Savory fatty & 12 & 5 & 1 & 1 & 1 & 0 & 0 & 32 & 3 & 38 & 2 & 26 & 3 \\
\hline Rice porridge, fish & Savory fatty & 12 & 5 & 1 & 0 & 0 & 0 & 0 & 42 & 4 & 33 & 3 & 29 & 3 \\
\hline Rice porridge, pork, with century eggs & Savory fatty & 12 & 7 & 1 & 2 & 1 & 1 & 1 & 30 & 3 & 43 & 2 & 28 & 3 \\
\hline Rice porridge, with salted vegetables & Neutral & 13 & 4 & 1 & 16 & 2 & 0 & 0 & 10 & 1 & 27 & 3 & 15 & 3 \\
\hline Rice, chicken-flavored, with fried chicken & Savory fatty & 12 & 26 & 2 & 10 & 2 & 0 & 0 & 28 & 4 & 27 & 2 & 36 & 2 \\
\hline $\begin{array}{l}\text { Rice, chicken-flavored, with roasted chicken, } \\
\text { Chinese style }\end{array}$ & Savory fatty & 12 & 5 & 1 & 0 & 0 & 0 & 0 & 26 & 3 & 39 & 2 & 40 & 2 \\
\hline $\begin{array}{l}\text { Rice, chicken-flavored, with steamed chicken, } \\
\text { Chinese style }\end{array}$ & Savory fatty & 12 & 8 & 1 & 1 & 0 & 0 & 0 & 29 & 3 & 38 & 2 & 48 & 3 \\
\hline Rice, coconut milk-flavored, Nasi Lemak & Savory fatty & 12 & 18 & 2 & 9 & 2 & 2 & 1 & 27 & 4 & 46 & 2 & 39 & 2 \\
\hline Rice, flavored, Briyani (rice only) & Neutral & 12 & 4 & 1 & 1 & 0 & 0 & 0 & 7 & 1 & 8 & 2 & 18 & 3 \\
\hline Rice, flavored, Briyani, with spicy chicken & Savory fatty & 12 & 5 & 1 & 4 & 1 & 1 & 0 & 23 & 3 & 25 & 2 & 34 & 4 \\
\hline Rice, flavored, Nasi dagang, with tuna curry & Savory fatty & 12 & 8 & 1 & 8 & 2 & 1 & 0 & 36 & 3 & 29 & 2 & 35 & 4 \\
\hline Rice, flavored, Nasi kerabu, with fried chicken & Savory fatty & 12 & 9 & 2 & 16 & 2 & 3 & 1 & 30 & 4 & 37 & 3 & 30 & 4 \\
\hline Rice, flavored, Nasi minyak, with chicken kurma & Savory fatty & 12 & 4 & 1 & 4 & 2 & 1 & 0 & 33 & 4 & 33 & 2 & 41 & 4 \\
\hline Rice, flavored, Nasi tomato, with spicy chicken & Savory fatty & 14 & 12 & 1 & 5 & 1 & 0 & 0 & 23 & 3 & 27 & 2 & 37 & 3 \\
\hline Rice, fried, Pattaya & Savory fatty & 12 & 9 & 1 & 4 & 1 & 1 & 0 & 28 & 3 & 30 & 2 & 36 & 4 \\
\hline $\begin{array}{l}\text { Rice, fried, with anchovy and water convolvulus, } \\
\text { Nasi goreng kampung }\end{array}$ & Savory fatty & 12 & 4 & 1 & 1 & 0 & 0 & 0 & 17 & 2 & 32 & 2 & 29 & 3 \\
\hline $\begin{array}{l}\text { Rice, fried, with chicken and frozen vegetables } \\
\text { Nasi goreng biasa }\end{array}$ & Savory fatty & 12 & 6 & 1 & 1 & 1 & 1 & 0 & 19 & 3 & 27 & 2 & 30 & 3 \\
\hline Rice, white, fragrant & Neutral & 20 & 3 & 1 & 1 & 0 & 1 & 0 & 3 & 1 & 1 & 0 & 5 & 1 \\
\hline
\end{tabular}




\begin{tabular}{|c|c|c|c|c|c|c|c|c|c|c|c|c|c|c|}
\hline \multirow[t]{2}{*}{ Food } & \multirow[t]{2}{*}{ Cluster } & \multirow[t]{2}{*}{$\mathrm{n}$} & \multicolumn{2}{|c|}{ Sweet } & \multicolumn{2}{|c|}{ Sour } & \multicolumn{2}{|c|}{ Bitter } & \multicolumn{2}{|c|}{ Umami } & \multicolumn{2}{|c|}{ Salt } & \multicolumn{2}{|c|}{ Fat } \\
\hline & & & $\mathrm{m}$ & SE & $\mathrm{m}$ & SE & $\mathrm{m}$ & SE & $\mathrm{m}$ & SE & $\mathrm{m}$ & SE & $\mathrm{m}$ & SE \\
\hline Rice, white, non-fragrance & Neutral & 12 & 5 & 1 & 0 & 0 & 0 & 0 & 1 & 0 & 1 & 0 & 3 & 1 \\
\hline Roll, cream, chocolate, Gardenia & Sweet fatty & 13 & 44 & 3 & 3 & 1 & 1 & 0 & 1 & 0 & 6 & 1 & 28 & 3 \\
\hline Roll, cream, corn, Gardenia & Sweet fatty & 13 & 35 & 2 & 4 & 1 & 0 & 0 & 1 & 0 & 7 & 1 & 25 & 2 \\
\hline Roll, cream, vanilla, Gardenia & Sweet fatty & 13 & 38 & 2 & 4 & 1 & 0 & 0 & 1 & 0 & 6 & 1 & 28 & 2 \\
\hline Roll, Swiss, chocolate & Sweet fatty & 12 & 47 & 2 & 0 & 0 & 2 & 1 & 1 & 1 & 4 & 1 & 29 & 3 \\
\hline Roti Canai, banana & Sweet fatty & 13 & 43 & 3 & 9 & 2 & 1 & 0 & 5 & 2 & 11 & 1 & 37 & 3 \\
\hline $\begin{array}{l}\text { Roti Canai, egg, (Roti telur) with dhal gravy and } \\
\text { sambal }\end{array}$ & Savory fatty & 13 & 11 & 2 & 8 & 2 & 1 & 0 & 13 & 3 & 33 & 2 & 30 & 2 \\
\hline Roti Canai, egg, (Roti telur) with dhal gravy & Savory fatty & 13 & 8 & 1 & 4 & 1 & 1 & 1 & 13 & 3 & 26 & 2 & 29 & 2 \\
\hline Roti Canai, plain, with dhal gravy & Savory fatty & 13 & 8 & 1 & 5 & 1 & 1 & 0 & 12 & 3 & 27 & 2 & 30 & 2 \\
\hline Roti Canai, plain, with dhal gravy and sambal & Savory fatty & 13 & 13 & 1 & 8 & 2 & 2 & 1 & 14 & 3 & 34 & 2 & 32 & 2 \\
\hline Roti Canai, tisu, with sugar and condensed Milk & Sweet fatty & 12 & 58 & 3 & 0 & 0 & 0 & 0 & 0 & 0 & 12 & 2 & 24 & 3 \\
\hline Satay, beef, with peanut sauce & Savory fatty & 13 & 26 & 2 & 4 & 1 & 2 & 0 & 32 & 4 & 24 & 2 & 44 & 4 \\
\hline Satay, chicken, with peanut sauce & Savory fatty & 13 & 26 & 2 & 3 & 1 & 2 & 1 & 30 & 4 & 23 & 2 & 44 & 3 \\
\hline Sausage, chicken cheese, fried & Savory fatty & 13 & 7 & 1 & 4 & 1 & 1 & 0 & 28 & 3 & 41 & 2 & 38 & 2 \\
\hline Sausage, chicken, fried & Savory fatty & 13 & 6 & 1 & 2 & 1 & 0 & 0 & 23 & 3 & 32 & 2 & 32 & 2 \\
\hline Sausage, Chinese, steamed & Savory fatty & 12 & 19 & 2 & 3 & 1 & 0 & 0 & 35 & 3 & 35 & 2 & 52 & 3 \\
\hline Soft drink, Coca cola, original & Sweet Sour & 15 & 49 & 2 & 23 & 3 & 3 & 1 & 0 & 0 & 3 & 1 & 5 & 2 \\
\hline Soft drink, F\&N, orange & Sweet Sour & 15 & 43 & 2 & 28 & 3 & 9 & 1 & 0 & 0 & 2 & 1 & 5 & 2 \\
\hline Soft drink, Fanta, grape & Sweet Sour & 15 & 53 & 2 & 26 & 3 & 2 & 1 & 0 & 0 & 2 & 1 & 5 & 2 \\
\hline Soft drink, Pepsi, original & Sweet Sour & 15 & 49 & 2 & 22 & 3 & 3 & 1 & 0 & 0 & 2 & 1 & 5 & 2 \\
\hline Soup, Chinese cabbage Pak-choy & Savory fatty & 13 & 9 & 2 & 0 & 0 & 1 & 0 & 39 & 4 & 33 & 2 & 30 & 3 \\
\hline Soup, fish ball & Savory fatty & 12 & 5 & 1 & 1 & 1 & 2 & 1 & 39 & 3 & 42 & 3 & 30 & 3 \\
\hline Soup, loofah & Savory fatty & 12 & 14 & 2 & 1 & 0 & 4 & 1 & 29 & 4 & 28 & 1 & 35 & 4 \\
\hline Soup, lotus root with pork spare ribs & Savory fatty & 12 & 8 & 2 & 2 & 1 & 0 & 0 & 33 & 4 & 38 & 2 & 36 & 3 \\
\hline Soup, pork ball & Savory fatty & 12 & 6 & 2 & 0 & 0 & 1 & 0 & 35 & 4 & 34 & 2 & 27 & 3 \\
\hline
\end{tabular}




\begin{tabular}{|c|c|c|c|c|c|c|c|c|c|c|c|c|c|c|}
\hline \multirow[t]{2}{*}{ Food } & \multirow[t]{2}{*}{ Cluster } & \multirow[t]{2}{*}{$\mathrm{n}$} & \multicolumn{2}{|c|}{ Sweet } & \multicolumn{2}{|c|}{ Sour } & \multicolumn{2}{|c|}{ Bitter } & \multicolumn{2}{|c|}{ Umami } & \multicolumn{2}{|c|}{ Salt } & \multicolumn{2}{|c|}{ Fat } \\
\hline & & & $\mathrm{m}$ & SE & $\mathrm{m}$ & SE & $\mathrm{m}$ & SE & $\mathrm{m}$ & SE & $\mathrm{m}$ & SE & $\mathrm{m}$ & SE \\
\hline Soup, sliced beef & Savory fatty & 12 & 5 & 1 & 10 & 2 & 1 & 0 & 38 & 4 & 36 & 3 & 34 & 3 \\
\hline Soup, tomyam, chicken & Savory fatty & 13 & 12 & 1 & 28 & 1 & 0 & 0 & 28 & 4 & 33 & 2 & 32 & 2 \\
\hline Soup, tomyam, seafood & Savory fatty & 13 & 12 & 1 & 30 & 2 & 0 & 0 & 39 & 5 & 33 & 2 & 33 & 2 \\
\hline Soup, wonton (pork dumpling) & Savory fatty & 12 & 5 & 2 & 1 & 0 & 0 & 0 & 26 & 3 & 34 & 3 & 32 & 2 \\
\hline Spinach, green, stir fried & Savory fatty & 12 & 4 & 1 & 0 & 0 & 2 & 1 & 22 & 3 & 25 & 3 & 30 & 3 \\
\hline Spinach, red, stir fried & Savory fatty & 13 & 3 & 1 & 1 & 1 & 3 & 1 & 19 & 3 & 34 & 2 & 27 & 3 \\
\hline Spread, butter, with bread & Savory fatty & 14 & 6 & 1 & 1 & 0 & 0 & 0 & 0 & 0 & 16 & 2 & 58 & 3 \\
\hline Spread, margarine, with bread & Savory fatty & 14 & 5 & 1 & 1 & 0 & 0 & 0 & 1 & 0 & 27 & 2 & 57 & 3 \\
\hline Spring roll, vegetables, fried & Neutral & 13 & 9 & 1 & 1 & 0 & 1 & 0 & 6 & 1 & 23 & 2 & 27 & 2 \\
\hline Squid ball, breaded, fried & Savory fatty & 12 & 6 & 1 & 2 & 1 & 1 & 0 & 32 & 2 & 24 & 3 & 26 & 2 \\
\hline Starfruits, fresh & Sweet Sour & 13 & 15 & 1 & 28 & 2 & 2 & 0 & 1 & 1 & 1 & 0 & 4 & 1 \\
\hline Stinky bean, stir fried with sambal and anchovy & Savory fatty & 12 & 11 & 2 & 7 & 2 & 8 & 1 & 28 & 4 & 48 & 3 & 35 & 2 \\
\hline Stout, Guinness Foreign Extra & Bitter & 12 & 4 & 1 & 24 & 2 & 68 & 2 & 0 & 0 & 0 & 0 & 3 & 1 \\
\hline Sweet corn, commercial, DailyFresh & Sweet fatty & 13 & 26 & 2 & 1 & 1 & 0 & 0 & 7 & 2 & 19 & 2 & 31 & 4 \\
\hline Sweet corn, steamed & Neutral & 12 & 15 & 1 & 0 & 0 & 0 & 0 & 0 & 0 & 2 & 1 & 6 & 1 \\
\hline $\begin{array}{l}\text { Sweet leaf bush, cooked with pumpkin and } \\
\text { coconut milk }\end{array}$ & Savory fatty & 12 & 22 & 2 & 0 & 0 & 3 & 1 & 32 & 4 & 26 & 2 & 35 & 2 \\
\hline Syrup, rose, bandung, with condensed milk & Sweet fatty & 13 & 53 & 3 & 1 & 1 & 0 & 0 & 0 & 0 & 0 & 0 & 13 & 3 \\
\hline $\begin{array}{l}\text { Syrup, rose, bandung, with evaporated and } \\
\text { condensed milk }\end{array}$ & Sweet fatty & 17 & 49 & 2 & 2 & 1 & 0 & 0 & 1 & 1 & 1 & 0 & 22 & 3 \\
\hline Syrup, rose, home recipe & Sweet Sour & 14 & 36 & 2 & 1 & 1 & 0 & 0 & 0 & 0 & 0 & 0 & 5 & 2 \\
\hline Syrup, rose, shop-recipe & Sweet fatty & 13 & 72 & 2 & 0 & 0 & 0 & 0 & 0 & 0 & 0 & 0 & 5 & 1 \\
\hline Taufufa, with brown sugar (soy bean mustard) & Neutral & 14 & 24 & 2 & 1 & 0 & 0 & 0 & 1 & 0 & 2 & 1 & 15 & 2 \\
\hline Taufufa, with white sugar (soy bean mustard) & Sweet Sour & 12 & 40 & 3 & 1 & 0 & 0 & 0 & 2 & 1 & 1 & 1 & 8 & 2 \\
\hline Tea, milk, 3 in 1 & Sweet Sour & 13 & 29 & 2 & 0 & 0 & 12 & 2 & 0 & 0 & 1 & 0 & 7 & 1 \\
\hline Tea, plain & Bitter & 20 & 3 & 1 & 1 & 0 & 24 & 2 & 1 & 0 & 0 & 0 & 2 & 0 \\
\hline Tea, with condensed milk & Sweet fatty & 20 & 37 & 2 & 1 & 0 & 11 & 1 & 1 & 1 & 1 & 0 & 16 & 2 \\
\hline
\end{tabular}




\begin{tabular}{|c|c|c|c|c|c|c|c|c|c|c|c|c|c|c|}
\hline \multirow[t]{2}{*}{ Food } & \multirow[t]{2}{*}{ Cluster } & \multirow[t]{2}{*}{$\mathrm{n}$} & \multicolumn{2}{|c|}{ Sweet } & \multicolumn{2}{|c|}{ Sour } & \multicolumn{2}{|c|}{ Bitter } & \multicolumn{2}{|c|}{ Umami } & \multicolumn{2}{|c|}{ Salt } & \multicolumn{2}{|c|}{ Fat } \\
\hline & & & $\mathrm{m}$ & SE & $\mathrm{m}$ & $\mathrm{SE}$ & $\mathrm{m}$ & SE & $\mathrm{m}$ & SE & $\mathrm{m}$ & SE & $\mathrm{m}$ & SE \\
\hline Tea, with sugar & Sweet Sour & 20 & 60 & 2 & 1 & 1 & 8 & 1 & 2 & 1 & 0 & 0 & 4 & 1 \\
\hline Tea, with sugar and lime & Sweet Sour & 20 & 40 & 2 & 29 & 2 & 7 & 1 & 1 & 0 & 0 & 0 & 4 & 1 \\
\hline $\begin{array}{l}\text { Tempe, (fermented soy bean), stir fried with } \\
\text { sambal }\end{array}$ & Savory fatty & 12 & 12 & 2 & 5 & 1 & 1 & 0 & 19 & 2 & 27 & 2 & 30 & 2 \\
\hline Tofu, braised & Neutral & 12 & 4 & 1 & 4 & 1 & 0 & 0 & 12 & 2 & 19 & 2 & 19 & 2 \\
\hline Tofu, egg, cooked with corn starch gravy & Savory fatty & 12 & 9 & 2 & 1 & 0 & 0 & 0 & 26 & 4 & 26 & 2 & 31 & 3 \\
\hline Tofu, firm, fried with sambal & Neutral & 12 & 13 & 2 & 8 & 2 & 0 & 0 & 9 & 2 & 14 & 1 & 10 & 2 \\
\hline Tofu, firm, stuffed Tauhu sumbat & Neutral & 13 & 19 & 1 & 8 & 2 & 0 & 0 & 4 & 1 & 6 & 1 & 17 & 2 \\
\hline Tomato, cherry, raw & Neutral & 12 & 9 & 2 & 23 & 3 & 0 & 0 & 35 & 3 & 1 & 0 & 6 & 1 \\
\hline Ulam, (local salad) lettuce, with sambal belacan & Neutral & 12 & 6 & 1 & 4 & 1 & 7 & 1 & 13 & 3 & 20 & 3 & 6 & 1 \\
\hline Ulam, long bean, with sambal belacan & Neutral & 12 & 6 & 1 & 5 & 1 & 8 & 2 & 12 & 3 & 13 & 2 & 5 & 1 \\
\hline Ulam, tomato, with sambal belacan & Neutral & 12 & 9 & 1 & 14 & 1 & 0 & 0 & 24 & 1 & 11 & 2 & 8 & 1 \\
\hline Ulam, winged bean, with sambal belacan & Neutral & 12 & 4 & 1 & 6 & 1 & 7 & 1 & 12 & 2 & 20 & 2 & 7 & 1 \\
\hline Ulam, cabbage, with sambal belacan & Neutral & 12 & 7 & 1 & 7 & 2 & 1 & 0 & 15 & 3 & 26 & 2 & 8 & 1 \\
\hline Ulam, cucumber, with sambal belacan & Neutral & 12 & 6 & 1 & 2 & 1 & 4 & 1 & 11 & 3 & 11 & 2 & 5 & 1 \\
\hline Water convolvulus, Kangkung, stir fried & Savory fatty & 12 & 2 & 1 & 1 & 1 & 3 & 1 & 19 & 3 & 30 & 2 & 37 & 2 \\
\hline $\begin{array}{l}\text { Water convolvulus, kangkung, stir fried with } \\
\text { sambal belacan }\end{array}$ & Savory fatty & 13 & 2 & 0 & 3 & 1 & 3 & 1 & 23 & 3 & 43 & 2 & 29 & 3 \\
\hline Water, filtered & Neutral & 20 & 1 & 0 & 1 & 0 & 1 & 0 & 1 & 0 & 1 & 0 & 0 & 0 \\
\hline Water, mineral, Cactus & Neutral & 20 & 1 & 0 & 1 & 0 & 1 & 0 & 1 & 0 & 1 & 0 & 0 & 0 \\
\hline Water, mineral, Spritze & Neutral & 20 & 1 & 0 & 1 & 0 & 1 & 0 & 1 & 0 & 1 & 0 & 0 & 0 \\
\hline Watermelon, fresh & Neutral & 20 & 25 & 1 & 1 & 0 & 0 & 0 & 1 & 5 & 1 & 0 & 2 & 0 \\
\hline White coffee, 3 in 1 , Old Town & Bitter & 20 & 32 & 2 & 1 & 0 & 42 & 3 & 2 & 1 & 1 & 0 & 14 & 2 \\
\hline White coffee, canned, Old Town & Bitter & 13 & 34 & 2 & 4 & 1 & 36 & 2 & 0 & 0 & 2 & 1 & 9 & 2 \\
\hline Young coconut, fresh & Neutral & 13 & 25 & 2 & 9 & 1 & 1 & 0 & 1 & 1 & 4 & 1 & 10 & 2 \\
\hline
\end{tabular}

